\title{
A SURVEY
}

\section{OF NATIONAL TRENDS}

\section{IN BIOLOGY}

\author{
EDWARD J. \%.K. MENGE
}


A Surcey of National Trends in Biology. Erward J. V. K. Menge. xi +156 pp. $\$ 2.00$. The Bruce Publishing Company. 1930.

This is a series of lectures surveying national trends in biology based upon replies to questionnaires sent to leading biologists of various nations. The lectures were prepared for the National University of Cordoba and for the Sociedade de Medicina e Cirurzia de Rio de Janeiro.

The author gives a very brief account of the development of the various fields of biology, some of the outstanding present day theories, and their effects upon our philosophical conceptions of living organisms. The treatise has a decided philosophical atmosphere and emphasizes the barrenness of the idea that a living organism is nothing more than a series of chemico-physical phenomena of the various elements of protoplasm and of the morphological units of the organism. It reads well and in interesting.

-C. L. Parmenter.

\section{Reviewed ing" Collecting Net"
Augus}


Fo the masime Bislugen $\ldots$

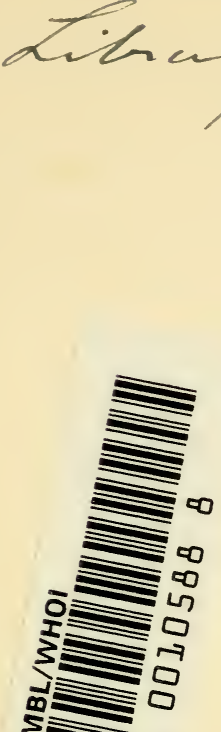

$\Sigma \ldots$

w

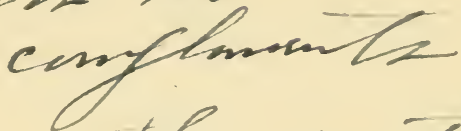

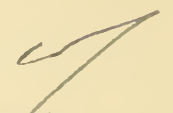

antef

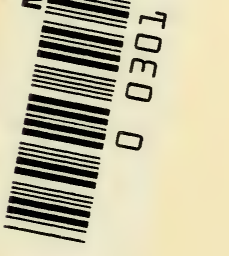



A SURVEY OF

NATIONAL TRENDS IN BIOLOGY 



\section{A Survey of National Trends in Biology}

By EDWARD J. v. K. MENGE, Ph.D., Sc.D.,

Director of the Department of Animal Biology in Marquette University

A Series of Lectures Prepared for the National University of Cordoba and for the

Sociedade de Medicina e Cirurgia do Rio de Janeiro (Brazil)

and Delivered at the National Universities of Cordoba (Argentina), Montevideo (Uruguay), and Santiago (Chile), and for the Sociedade de Medicina e Cirurgia of Rio de Janeiro during August and September, 1927

THE BRUCE PUBLISHING COMPANY MILWAUKEE 
Copyright, 1930

EDWARD J. MENGE

Printed in the United States of America 
MARCELINO HERRERA VEGAS

Argentina's most distinguished medical man

FRANK R. PASMAN

Dynamic personality of Argentine medicine

BENITO SORIA

Official scientific representative to foreign lands of

Argentina's oldest University

GUILLERME V. STUCKERT

Cordoba's distinguished biochemist

JOSE PIZARRO

Scholarly Dean of the Faculty of Medicine, Cordoba

LUCAS SIERRA

Most outstanding of Chile's gifted surgeons

VICTORINO ALONSO

Most kindly of scientific philanthropists

CARLOS PORTER

Foremost entomologist of all South America

JUAN NOE

Chile's energetic physiologist

O. FONTECILLA

Able Chilean scientific editor

ALEJANDRO MANHOOD

Forceful director of the world's most interesting dental school

JUAN POU ORFILA

Philosopher Dean of Uruguay's National Medical School

CARLOS ENRIQUE PAZ SOLDAN

Outstanding Peruvian hygienist and scientific editor

JOSE MENDONCA

Dean of Brazilian Surgeons

NASCIMENTO GURGEL

Gifted President of the Sociedade de Medicina e Cirurgia of Rio de Janeiro

and that remarkable scientific family

OLYMPIO DA FONSECA

Embodiment of Brazilian culture and his two gifted sons

OLYMPIO DA FONSECA, FILHO

Traveling Representative of the Instituto Oswaldo Cruz

and

FLAVIO DA FONSECA

Microbiologist of the new Sao Paulo Medical School 



\section{PREFACE}

Due to a number of discussions with the late Professor Wm. A. Locy, America's foremost historian of biology, the writer had begun a survey of contemporary biological literature some years back. It was but natural, therefore, when two invitations were extended at almost the same moment, (1) by the editors of a new encyclopedia for an article on Modern Progress in Biology, and (2) by the University of Cordoba to deliver a series of international lectures at a number of South American universities, that the material already collected should be extended and woven into a connected whole.

As the lectures were to be presented to an audience composed of faculty, students, and the general public, it was felt necessary to begin the series with the introduction here given. This, primarily, so that the coördination, the correlation, and the interrelationship of the efforts of many workers in many lands could be better appreciated - a coördination, a correlation, and an interrelationship that alone can bring forth a perfect product of any science. And in biology, the health, the happiness yes, the very life of each of us depends upon this product.

After the survey of the literature had been made, letters containing a number of questions were sent to the heads of departments of biology and zoölogy in every university in the world outside of the United States, and some 
twenty in the United States. The letters were written in English, German, French, and Spanish, thus permitting each recipient to write in whatever medium he found best suited to express himself freely.

The questions asked were:

1. What do you consider the most important work done in biology generally, and in your country particularly, during the past thirty years? Why? (a) From a purely scientific point of view? (b) From the point of view of service to humanity?

2. What biological problems have been solved during that time?

3. (a) In what specific fields have most of the biological workers been employed? $(b)$ What gave the impetus which brought about the interest in that specific field?

4. What do you consider the most fundamental problems of biology today? Why?

5. What in your opinion is the position of the ablest biological workers of your country in regard to vitalism and mechanism?

6. What work in biology, if any, has had sufficient influence actually to change the life of your people in any way, in politics, education, philosophy, psychology, religion, etc.?

7. What matters, not specifically asked for in the above questions, do you think should be covered in an article giving a biological survey of our generation?

It will be noted that none of the questions could be 
answered with a simple yes or no. The questions were put so that there would be no suggestion of any "wished-for" answer in order that the correspondents express only what each wished to express.

In view of the fact that answers were received from every region of the world, in which Minerva lists even a single university, excepting the Philippines, China, Egypt, South Africa, and the Balkan Peninsula, the summary and classification of these answers, plus the opinions and findings extracted from a general survey of the biological literature of this generation, can truly be said to represent a real cross section of present-day biological thought.

The responses were so numerous and generous and so much more complete than I had expected, that the simple thanks I can here accord, is by no means in keeping with what these men deserve. I therefore wish to extend to them not only my personal thanks, but that of my South American audiences as well, who were loud in their praise of these men.

Most of the lectures have already appeared as separate articles, both in English and in Spanish, in such journals as The Quarterly Review of Biology, The Journal of Social Psychology, La Clinica of Santiago de Chile, and in various specialized Reviews of this and other lands.

Edward J. v. K. Menge

Marquette University,

Milwaukee, Wisconsin,

January, 1930 



\section{TABLE OF CONTENTS}

PAGE

Preface . . . . . . . . . . . vii CHAPTER

I. INTRODUCTION . . . . . . . . . 1

II. Facts and Findings . . . . . . 20

iII. A Cross Section of Present-Day BiologICAL Thought . . . . . . . . 48

IV. Provocative Biological Theories . . . 72

V. Outstanding Biological Work and WorkERS • • . . . . . . . . . 92

BIBLIOGRAPHY . . . . . . . . 124

INDEX . . . . . . . . . . 147

\section{4}





\section{A SURVEY OF NATIONAL TRENDS IN BIOLOGY}

\section{CHAPTER I}

\section{INTRODUCTION}

Señor Rector, Señores Decanos, Señoras y Caballeros:

Permit me to extend to you the greetings of Marquette University, whose representative I have the honor to be, and to express the hope that this beginning of an intellectual exchange between the North and the South American universities, may lead to a better understanding and appreciation of the work that each of us is doing.

I also bring to you the personal greetings and good wishes of one well known to all, Dr. Franklin H. Martin, Director-General of the American College of Surgeons.

It had ever been a dream of mine that some day I might visit the second-oldest university in either of the Americas - that of Cordoba - whose very name carries with it visions of history and of romance. But I did not dream that out of a clear sky an invitation would be extended to me - the first, you tell me, extended to a North American - to speak from this platform and in this room, hallowed for more than three centuries by its association with history and learning. If I can but give 
to you, when delivering these lectures, a portion of the pleasure which $I$ have had in preparing them for you and in coming to you, I shall be well repaid.

The historian must always refer and defer to what others have said. The philosopher must show that logically a definite result follows from a given set of events, and then must use this result as a basis for his next step in proceeding. All such reasoning, however, is extremely vague to the average man - entirely too abstract. And, what the average man does not understand, he feels instinctively is either erroneous or worthless, or that it is some catch affair which will result in his undoing. Thus, he will blindly accept everything from those whom he considers his superiors, or he will ignore everything that he thinks those in power are using to weaken an already wavering hold on positions and responsibilities attained by him during the last century. He has learned just enough, as Lamartine has aptly pointed out, to be seriously influenced by logic, but not enough to know sophistry when it is presented to him.

The scientific man has a great advantage over the historian and the philosopher, in that he need not carry volumes with him to prove a statement. He works with the very subject matter and standards of measurement used daily by everyone in some degree - his senses. The scientist's discussions and findings are stated in a language understood by everyone, to a certain extent - the statement of what he actually sees, and hears, and feels. 
Science, therefore, has become the touchstone of the man in the street - his watchword of all that will bring him not only the comforts of life, but the satisfaction of absolute certainty as to how to obtain happiness. How far from the truth such an idea happens to be, we all know, for happiness is a matter of the spirit, and has little if anything to do with wealth, position, power, learning, or science. But we must never forget that an idea once held is just as powerful as a driving force, whether it is true or not. Science is the lone magic word to the average man; and when experiment after experiment is presented to show that always, under the same conditions, identical results are obtained, he is impressed. He understands that it must be so, even if he cannot understand its use nor to what the various interpretations given these findings may ultimately lead.

If he cannot understand this simple language of experiment and observation, he is excluded from the field of human understanding.

Science aims to control nature, and to prophesy the event or events that will follow on the performance of a very definite act or a combination of acts.

I like that definition of science best which calls it the "checking up and getting rid of one's prepossessions."

It is often said that men formerly took all their facts from authority, but that now they have attained such mental heights that they seek facts only at first hand. While it may be admitted that many facts were taken 
on authority in the past, we must not forget that all modern fads, whether in medicine, politics, or religion, are the result of accepting interpretations on the authority of modern interpreters, just as men of the past accepted authority of facts.

For facts in and of themselves are worthless; it is what they mean that counts, and meanings are always to be found only through a logical, philosophical interpretation of whatever facts may be at hand. Such facts must, of course, be obtained from actual experimentation; that is, by demonstrating that identical results are always forthcoming, when the same act or combination of acts is performed.

It is interesting to compare the work done in the scientific laboratory with that of the photographer. The efforts of each certainly show a striking similarity, for are we not really trying to present a picture to the world? Therefore, with the photographer, we must:

1. Clear away all that is unimportant.

2. Choose a subject.

3. Have the proper perspective; that is, have the relationship of everything about the subject in proper form, so as not to unduly stress any one point. In other words, we must see that we have taken everything into consideration. We must be sure that no other branch of science has points and conclusions which may destroy our own, since, if a single exception is found in science, it destroys the law. 
4. Have sufficient light to make the subject stand forth so as to be seen clearly. This implies a proper background - a background built up in the study of science by ascertaining what has gone before, and what causes have produced the particular historical soil upon which the seed of men's ideas have been able to grow. In other words, we wish to have all the facts that can be found, so as to throw the subject under consideration into the full glare of day. Shadows should be excluded as much as possible.

5. See that the subject is in focus, which means that in any given case, it must stand forth in bold relief. It must not fade away in the distance and become blurred by prejudices or desires. No vagaries of thought must be permitted. Our reasoning must be clear and definite. Our whole system must be built up philosophically and logically.

6. Decide upon how large an opening we are to allow our lens; that is, within what narrow limits we are to discuss the subject under consideration.

7. Decide upon the length of time for the exposure, which, in a scientific treatise, means that we must know that sufficient time has elapsed to make our experiment valid and positive.

8. If we read of the results of others, take into consideration the temperamental make-up of the individual writing as well as of ourselves and other readers who later are to pass judgment thereon. 
In the fields of chemistry and physics, for example, using two nonbiological sciences, one is very definitely limited to certain specific substances and to the laws of force, light, heat, and electricity. In biology, dealing as it does with everything that is living or pertains to life, there is practically no limit to one's field of endeavor. Whether we think of the great North American chewinggum industry or the price of cotton and coffee, everything which comes to mind in connection with such topics is in some way involved in the subject of biology, for life means everything that grows and moves, and develops from the inside outward. Life includes all the plant and animal world. Within its boundaries, the range of investigation may run from a study of the diseases of plant crops and the parasitic enemies and diseases of your herds of cattle, to the length of life allotted to yourself and family. Every step is determined by a biological law; and to learn that law and apply it, is the great fundamental object of every biological worker, from those who specialize in entomology and plant pathology to human medicine.

What a tremendous difference the efforts of such workers have made upon the entire world may be judged by a few examples. As several writers have pointed out, the downfall of the classic civilization of bygone days was undoubtedly due to the malarial mosquito. Epidemics of the past, breaking out in times of war, have completely changed history.

Many archæologists hold that yellow fever was the 
cause of the downfall of prehistoric American civilizations, while a number of writers are convinced that an unprecedented era of progress is now facing Latin America, due primarily to the conquest of that dread disease.

If the world had had biological workers years ago who were able to prevent cancer, so that the father of William II had not died within three months after ascending the German throne, all Europe might have been different from what it is.

Biological workers may rightfully claim to have influenced the world a thousandfold more than rulers and warriors, for this latter group has largely been given to destruction, while the work of the biologist aims to be constructive. Generations now unborn will profit by his work. His efforts become increasingly interesting and vitally important, and, being concerned with life in all its ramifications, his field is inexhaustible.

The combined and coördinated efforts of a great many separate workers, scattered through many lands, usually are necessary to bring a scientific idea to full fruition. This is well shown in the work on typhoid fever, a disease of especial interest to you who have so many typhoidendemic centers.

Huxham, as long ago as 1737, described the difference between typhoid and typhus fevers, although it took nearly a hundred years before a careful study of the actual lesion (not the external symptoms) brought forth the true difference and relationships of the two. Wm. Gerhard, of Philadelphia, established this difference and relation- 
ship in 1837. Then, in 1880, Carl Joseph Eberth, professor of histology and pathology in the University of HalleWittenberg, described the bacillus typhosus which he found in the tissues of patients who had died of typhoid fever. In 1884, George Gaffky, professor of hygiene in Berlin, succeeded in growing these bacteria in a pure culture.

In 1888, Chantemesse, professor of hygiene in Paris, and Professor Widal, of the department of pathology in the same city, inoculated mice with typhoid bacilli, which had first been killed by heat. The mice became immune. In 1892, these men were able to produce immunity in guinea pigs and rabbits. Professor Brieger, the hydrotherapist of Berlin, Professor Kitasato, the pathologist of Tokio, Professor Wassermann, the experimental therapist of Berlin, and Professor Bruschettini confirmed previous results.

In 1894, Pfeiffer, a German physician, and Kolle, the bacteriologist in Berne, Switzerland, used antityphoid vaccination in the human body. Two years later, Sir Almroth Wright of London, began a systematic vaccination of human beings on a large scale, and in 1899 Chantemesse of Paris, vaccinated the personnel of his hospital.

In 1900, two Russians, working in Paris, Metchnikoff and Besredka, produced the disease in apes experimentally, thus establishing the final proof of the relationship between the germ and the disease. From that time onward, control measures were possible. 
In fact, the principles thus established by a host of workers in many lands, were successfully applied to anticholera vaccinations by Haffkine, a pupil of the great Louis Pasteur, in 1894, thus overcoming another dread terror of humanity.

These results were obtained from dealing with things we can see and handle - that really come under the senses. But what are we to say about other nonseeable things we know exist, though we cannot bring them under our limited spheres of sense?

Under this heading one may mention those colors, such as the infra-red and ultra-violet rays which no human eye can see, but which we can prove actually exist in any physical laboratory. If we turn these rays, invisible to man, upon a group of brown ants, they immediately sense them, for they scamper away hurriedly. How do these ants sense that which we cannot? We do not know.

Such experiments, however, show us why men come to some interesting and remarkable conclusions which would otherwise be extremely difficult to understand.

From such findings, the late Professor A. D. Darbishire ${ }^{1}$ came to the conclusion that there must be a great many colors which the human eye cannot see, and many sounds which the human ear cannot hear. Therefore, just insofar as we accept any plausible physical theory which fits into every angle of our mind, should we be the more suspicious of it. Such a theory may fail to take into account the thou- 
sands of things which must be considered if all the facts are to be known, yet which never can be known, because of the limitations of the human senses and the human intellect.

Professor William Wundt, the first man in the world to open a psychological laboratory, came to the conclusion that "animals never think and humans but seldom." This conclusion was drawn from experiments akin to the following:

If we put a glass tube into the duct from the parotid gland of a dog (this is the gland which swells when one has mumps; it also pours out the secretion which makes the "mouth water"), we can count the number of drops of secretion which come forth normally in a given time. If we now allow the animal to smell a piece of meat, the secretion comes forth in the same manner but with increased rapidity. Suppose, then, we take a small amount of hydrochloric acid and place it under the tongue. The secretion increases to the same rate as it did when the dog smelled meat. If, now, we blow a whistle some twenty times at the precise moment the acid is placed under the tongue, thereafter we only need to blow the whistle to obtain the same result. The association of whistle and acid has become so strong and so thoroughly connected that one has the same effect as the other. But if the tone of the whistle is changed, the same result will not be produced.

Such experiments prove that even so complicated and 
supposedly conscious an action as recognizing a tasty food can, in a short time, become nothing but a mere mechanical and associative action.

"Yes," you may say, "we can understand all that, but why experiment on individual cells, and on one-celled animals; what good to humanity can one hope to find there?"

I think the most satisfactory way to acquaint the nonbiological listener with the underlying reasons for experimental work on such individual cells of the body and on one-celled organisms, is to show how such work changes our whole conception of the treatment of disease in both the physical and the mental realms. I quote the words of Dr. Stephen Smith, an eminent psychiatrist of the generation just passed. He says:

"The lessons which the illustrations of the anatomy and physiology of the nervous system teach, have a wide application to our treatment of the dependent classes. We learn that the mental attributes of every person depend ultimately upon the physical state of the cell, over which we have almost absolute control in its individual and collective capacity. If its texture is feeble from heredity or disease, we may make it strong by nutrition, exercise, pure air, and medication; if it is undeveloped, we can develop it by applying appropriate stimulus and suitable nourishment; if it is unduly developed and overactive, we can reduce it to a rudimentary and inactive state by removing every form of stimulant and reducing its nutri- 
tion; where neither the regulation of the stimulant nor the nutrition accomplishes our purpose, we can rely upon specific remedies.

"The logical and inevitable conclusion is that, if we thoroughly understood the exact function and the functional relations of all the cells of the nervous system, we could, beginning with the child, control in a large measure the development of his character, and in the adult, modify existing attributes by stimulation of one class of nerve cells and the repression of another to any extent that we desire. Nothing can be more thoroughly practical than the application of the proper remedial measures by which the equilibrium of these centers is secured."2

It also should be said that while Dr. Smith discusses here only the nervous system, every additional fact learned about the individual cell brings us just that much nearer accomplishing the desired results. And as the onecelled organism must perform all the functions of life that man performs with his highly specialized organs, composed, in turn, of individual cells, there is no place that one may hope for more biological light to be thrown on all the activities, normal and abnormal, physical and mental, of man, than through the knowledge gained by experimental work on these lowly organisms.

One of our leading scientific insurance investigators ${ }^{3}$ of the ills of human kind, tells us that every conceivable form of influence that can possibly shorten human life is contained in the following eleven categories: 
1. Heredity: always influential and sometimes definitely and hopelessly limiting the life span.

2. Infection: acute or chronic, by bacteria or parasites - probably the most potent cause of disease, old age, and death.

3. Poison: from within or without; drugs, occupational poisoning, endocrine (glandular), or other disturbances releasing poisons or interfering with their elimination or destruction; protein sensitization.

4. Food deficiency: general, as in a lack of sufficient food; or specific, as in a lack of some particular food substance - mineral, vitamin, amino acid, regulating food, and so forth.

5. Food excess : general, as in overeating; or specific, as in excessive consumption of meat, sugar, or starches.

6. Hormone deficiency: as in endocrine, or other organic deficiencies. Hormone deficiency is probably the greatest immediate factor in limiting the life cycle. It implies a lack of some substance or group of substances whose function is to stabilize the tissues in a state of health.

7. Hormone excess : as in the opposite state of endocrine overactivity.

8. Physical trauma: an obvious factor in life destruction, yet even physical overwork is not so often the cause of organic strain or injury as was formerly thought. The yielding organ is probably already damaged by infection or poison. 
9. Psychic trauma: this is becoming more and more thoroughly understood. While there, too, we must look for underlying physical insufficiencies, inherited or acquired, it is no doubt true that the psyche may become so profoundly injured as to react upon the physical state and shorten life. Fear, grief, and emotional excess are, however, more destructive than mental effort or mental work.

10. Physical apathy: lack of muscular effort and faulty muscular development are justly charged with degenerative effects.

11. Psychic apathy: this is evidently the cause, as well as the result, of failing physical powers; lack of interest in life induces physical apathy with its attendant evils.

You will notice that every one of these eleven categories refers only to a production of the individual cells or an injury to the individual cells.

But the biologist is not working only to overcome disease and add a few more years to life. When someone was hurrying that great Chinese statesman, Li Hung Chang, along so that an especially fast train could be caught, he stopped dead still to ask why they had to catch that particular train to begin with, and when told that they would thus save ten minutes, the whole wisdom of the Orient came forth in his query, "What are you going to do with the ten minutes?"

"To the biologist the measure of success in living is the accuracy with which living things fit themselves into 
their environment. How thoroughly have they taken conditions and turned them to their advantage?"

"In man this signifies not only the taking advantage of things as they are, but in shaping and directing these and creating new conditions and circumstances for his welfare." 4

So in the economic world, all the physical progress and all the physical comforts that modern civilization has given us are the direct result of applying laws found in the scientific laboratory. All wealth is not produced by labor, as the ignorant believe, but is the product of brains; labor is productive only when guided by intelligence.

In fact, science emancipates labor. Bagehot is one of a growing school of thinkers who has pointed out that slavery was essential to progress in the early stages of civilization, as it was only through enforced labor of the many that the few could obtain the leisure to think, and if that thinking by the few had not been done, all would have been destroyed.

At present in the United States, as Dr. Little has pointed out, "the supply of available energy is equivalent to sixty man power for every man, woman, and child." But, he adds, that "while there is now leisure for all to think, the millions prefer the movies."

It is not labor, but the trained intelligence of scientific men which has made all this power available. No more do we have at regular intervals the seven lean years and the seven fat years that Joseph foretold in Egypt. 
President Coolidge said not long ago: "Everything that flows from the application of trained intelligence and invested capital is the result of brains. The man of trained intelligence is a public asset. We go forward only through the trained intelligence of individuals, but we, not the individuals, are the beneficiaries of that trained intelligence: in the very nature of things we cannot all have the training, but we can all have the benefits."

The great principles and fundamental laws which make possible scientific progress can never exist through mere labor, nor through the politician, but only through that trained intelligence which can read the book of nature correctly. Here, there is always something new and important for the discerning eye.

Make a list of the contributions to the welfare of man, and see how practically all were made by the so-called upper and middle classes, or precisely those whom the social revolutionist always wishes to destroy first, though he owes everything to them.

"One may recall that Lavoisier was guillotined by a republic that had no need of chemists; that Priestley was driven from his sacked and devastated home; that LeBlanc, after giving the world cheap alkali, died in a French poorhouse; that Langley was crushed by ridicule and chagrin in his last days. A month before the war, who could have believed that within a few years the Fifth Estate in Russia would be utterly destroyed, and that in Germany and Austria it would exist at the very edge of 
starvation. What has happened there may happen again elsewhere, if the intelligence of the world does not assume and hold its proper place in the direction of national and world affairs.

"In the preface to his recent Lehrbuch der Photochemie, Professor Plotnikow has written: 'Home and property were pillaged by bands of idle Russians who used my library for cigarette papers. Hunger, misery, want, and personal insecurity, often approaching fear for my life, were the constant accompaniment of my labors.' "'7

Professor Cockerell says in this regard:

"Surely mankind has not deserved the services of its benefactors if we judge by the way it has behaved.

"Yet this is by no means the worst of it. Children, old and young, often react to some delicate toy or instrument by smashing it at once. Sometimes they use it to smash other people. So it has happened that gifts of science have been wantonly misused, and we sometimes wonder whether our species will not eventually exterminate itself as a result of knowing how. Thus with enormous increase in the means of production, with facilities of transportation undreamed of a few years ago, with marvelous control over disease, we still have war and greed, to which these great services are actually made to minister.

"We must all admit that the remedy for this state of affairs does not lie wholly in the scientific realm. Without a sense of human values, for which mechanistic science has no justification, we can attain no real virtue. Ulti- 
mately, all payments have to be made in the bank of consciousness, the operations of which can only be superficially described. Nevertheless, as a horseman desires to have a good mount, so we desire the means of riding through life without being trampled underfoot. Science, if asked, will provide this mount, at least if given sufficient notice ahead. Yet we, on our part, must learn to ride."

But it must not be forgotten that the scientist, too, has obligations toward his public. Dr. Lewellys Barker speaks in no uncertain terms, ${ }^{9}$ as did also Dr. Pritchett, President of the Carnegie Foundation, a few years back, on the matter of calling every paper published, scientific. Dr. Barker speaks particularly of medicine and dentistry, but his words may be applied to a good many other fields of work.

Speaking of this "pseudoresearch," he says:

"The general haste to rush into print with results that are not sound is harmful to both the public and the less well-informed practitioners. The intellect and imagination of the research worker should be of high order, and the work should be under the direction of experienced investigators. The mistakes of work so executed will be fewer and less serious than those of workers of less ability and experience. The face of the medical professions generally should be set against pseudoresearch that is irresponsibly undertaken and is inaccurately conducted. It is a degradation to science and misleading to the public that the true scientist tries to serve." 
Every faction in the world's social order either praises or blames science for contributing the coin with which the physical purchases of life are made, and the scientist is obliged to admit that both are right.

But, let us not forget that the scientist can only furnish the coin. That it will take a long time for the world to learn to buy judiciously, is not his fault. Neither is it his fault that many counterfeit coins are in circulation and that altogether too many people really believe the worse product the better. His work is to increase the quantity and the quality of the coin used, so as to make more and better purchases possible. Training mankind how to buy and where to buy is the work of the sociologist, but even his work is dependent upon a thorough understanding of values, and values fall into two leading groups. The one group is physical, and an understanding of physical values is attained through the universities and the great scientific teachers; the other lies in the pathway of the spirit, and spiritual and moral values rest with religion. Physical science can but present a motive. It lies with religion to furnish the obligation.

\footnotetext{
${ }^{1}$ Darbishire, A. D., An Introduction to a Biology, 1927.

${ }^{2}$ Smith, Stephen, Who Is Insane? 1916.

'Fisk, Eugene Lyman, "Prolonging Human Life," Yale Review, July, 1920.

"McClung, C. E., "The Contribution of Biology and Its Application," Science, March, 1927.

'Little, Arthur D., "The Fifth F.state," Science, Oct. 3, 1924.

'Ibid.

Tltid.

'Cockerell, T. D. A., "Duty of Biology," Science, April 9, 1926.

"Science News, "Coöperation Between the Medical and Dental Professions," Science, May 14, 1926, p. xii.
} 


\section{CHAPTER II}

\section{FACTS AND FINDINGS}

With the approaching centenary of the first successful attempt at manufacturing an organic product in the laboratory, it is but fitting that the eyes of scientific men should scan the century, take pride in the marvelous progress of the biological sciences, search for the causes of failure, and evaluate experimental evidence and philosophical interpretations. It is further fitting that we should know what the contributions of men of all lands have been, lest we fall into the common error of nonscientific men - that of assuming that because a problem, a fellow worker, an emphasis, or a philosophy of life is close at hand, and thus considered important by friends and coworkers, it therefore takes precedence over all the remaining universe.

The history of science during the nineteenth century has been written so well by those who have preceded us that it would be presumptuous on my part to try to improve upon it. Little, however, has been written regarding our own generation, or the work of contemporary men. Consequently, this lecture will be confined to a statement of what the ablest workers in the biological sciences believe to be important and well worth while. 
Yet, here again, the field has become so vast, the work so varied, and the contributions so numerous, that one may well throw up one's hands in dismay, especially when it is noted that the editors of Biological Abstracts have listed forty-seven major subjects under which to classify the work of biologists. ${ }^{1}$ And each of these forty-seven major subjects has usually at least one or more subheadings of branches of biology in which men are specializing.

If Johannes Müller, as it is often stated, broke down, mentally, trying to keep abreast of the literature on physiology about the year 1857, when physiology had just come into existence during his lifetime, how can any one person, now, when thousands upon thousands of papers are being published annually, even approach success in such a plan?

I do not believe that anyone can do so successfully, nor do these lectures make any claims toward furnishing even an approximately complete answer. We can but attempt to form a nucleus which may be of service to others interested in the pathway biology is now following. It will be a starting point that will give the future historian of biology some threads with which to weave his tapestry, which threads the ablest present-day biologists consider of exceptional import.

These same distinguished scientists, leaders in their respective branches of biology from every country of the world where even a single university has been established, will, however, speak for themselves. I shall not evaluate, 
but merely attempt to state the case and so produce a living document at least of interest to the younger workers in the field.

Just fifteen years ago, C. S. Minot, of Harvard, then Exchange Professor at the Universities of Berlin and Jena, delivered six lectures on "Modern Problems of Biology" at the latter institution. ${ }^{2}$

The six problems discussed were:

1. The New Cell Doctrine

2. Cytomorphosis

3. The Doctrine of Immortality

4. The Development of Death

5. The Determination of Sex

6. The Notion of Life

Today, at another foreign university, another North American professor reads a paper on a similar theme - "A Survey of National Trends in Biology" - dealing with the problems of biology as they appear to the biologist of all nations fifteen years later.

It is undoubtedly true that science should know no political boundaries, and that as biology is a science, it should be international. However, one need be in correspondence with but a very few biologists to find that while biology may be international, biologists certainly are not.

The answers to the letters mentioned in the Preface, reflected the same national feeling that one would find in men whose training, or lack of it, is not expected to 
help them control their emotions or render impartial judgments on matters that come before them.

As the answers continued coming in, a great temptation presented itself to change the title from "A Survey of National Trends in Biology" to that of "The Psychological Reactions of Biologists," but a calmer judgment prevailed.

Political, religious, educational, and traditional boundaries are so much a part and parcel of the human individual that, try as he will, he can never avoid being influenced by them.

One letter was filled with the bitterness of life because of his country's partition, leaving but an insignificant group of hillocks, as the writer put it, which men now force him to call by the name of a country, for centuries great and glorious. He no longer feels he has a Fatherland. For him, his country has ceased to exist. Another breathed of hope and looked with patriotic enthusiasm to a wondrous future following the birth of a new Fatherland whose racial and national ambitions have had to lie dormant almost since time immemorial.

Let us note in what specific fields of biological endeavor the majority of experimenters have been working during our generation, and what it was that gave impetus to such work.

While all nations had many men employed in various departments, such workers find themselves in certain 
more or less specific fields in their respective lands, due to geographical conditions rather than political boundaries. For instance, one finds Canada and the Scandinavian lands with vast coastal lines always interested in fisheries and all that relates to them. But we shall let the Norwegian biologist, Hjalmar Broch, speak for himself :

"A survey of the biological works in Norway in many respects shows that geographical conditions play a predominant part. On the one hand, we are situated in the periphery, and we see how 'moves' prevail in theoretical studies. During the first years of the century the cytological mania which had already culminated in Central Europe, also made its way to our university, and gradually faded away again some time after it had played out its predominant part in Germany. Then studies of heredity made their way northward, and are at present $\grave{a} l a$ mode to a degree that every student of biology finds it his duty to bestow a tinge of this on his theme, however far the latter in reality may be apart from the field of heredity investigations. In many cases we can trace this mania backward to the rise of certain leaders of little originality who wish to be à la mode, so as to get a place among the real leaders of the epoch.

"There is, however, one field of biology that runs like a real thread through the history of Norwegian biological science - the ocean. From the earliest times, our nation has been a nation of sailors and fishermen, and it was from the beginning but natural that the attention of Norwegian 
biologists should also be roused by the sea, the country having a coastal line of more than 3,000 kilometers, whereas its breadth is in most part quite small.

"The great traditions given by such zoölogists as Johan Ernst Gunnerus, Michael Sars, and Georg Ossian Sars, have naturally put their stamp on Norwegian biology, and the most important biological contributions are naturally connected with marine research."

Likewise in Canada, considering biology as it applies to economics and industry, we find that the most important effort mentioned is the coöperative development by the Canadian universities of economic fisheries research, including the formation of the Biological Board of Canada, and the establishment of marine laboratories. Saunder's work on Marquis wheat has made "millions for Canada," and better still, it has created the atmosphere of economic adjustment of plants and animals to northern environments. The production of Marquis wheat, a pure example of the older selective breeding, was the direct response of a practical-minded man to solve a particular Canadian or northern-American problem of high yield and short season.

In the United States and in other countries, where many new types of plants have been imported, an international exchange of both useful and deleterious insects has been made. Entomological work of ascertaining "which is which" and trying to bring back that much-needed balance in nature which keeps plants in good health and 
growth, also has been pursued. Many insect pests flourish in their new homes because those particularly predaceous and parasitic insect enemies which ordinarily keep them in check, are not imported with them. But an interesting work has grown up in finding what these insect enemies are and importing them.

In connection with work of this nature, one can show how some of the larger animals may be and are conserved by an international coöperative union in this study. Kel$\operatorname{logg}^{3}$ calls attention to the fur seals of the Pacific, which were rapidly approaching extinction on account of unrestricted killing on the high seas as well as on their breeding grounds in the Pribilof Islands, when international agreements made in 1911 among Great Britain, Russia, Japan, and the United States saved them as a species and at the same time allowed a reasonable taking of skins.

This geographical aspect is also prominent in the report of the last meeting of French scientists. ${ }^{4}$ Due to economic conditions, the Colonies must be developed; President Alfred Lacroix particularly stressed the part that science must play in the development of Tunis, Algeria, Morocco, Senegal-Niger, Guinea, the Congo, Indo-China, and other regions under French control. In fact, this year's meeting of the French association is to be held in Constantin, Algeria. Even Dr. Voronoff, the gland surgeon, has passed from human gland transplantations to work on farm animals, with a view toward producing heavier sheep bearing more wool. And Australia, a very few years back, spent 
something like $\$ 600$ per $\operatorname{man}^{5}$ to bring a group of scientists to its shores, hoping that some of her own particular problems would and could thus be solved.

Nearly all biologists consulted, thought that the economic side of their science was of considerable, though by no means of greatest, importance, and by this term some included everything in the way of human relationships. In fact, the term "human biology" is used by several, as referring to the relations of man to his environment; that is, to the way biology is applied to economics, to medicine, to education, to sociology, and to psychology.

In the United States, biological workers have been employed probably chiefly in experimental general biology, and in genetics, in embryology, cytology, tissue culture, and in general physiology.

In genetics, the impetus came through the work of Mendel, Weismann, and Roux in European countries, and in the United States through that of Wilson and Morgan.

J. Stanley Gardiner, of Cambridge, holds that history fertilizes the scientific soil, and that there is a considerable correlation of science with any profound disturbances which cover wide areas. Thus:

"China for 6,000 years has altered very little, and shows little advance. Our great advances in Europe are correlated with (1) the dominance of Spain and the profound wars in the sixteenth century; (2) the Cromwellian and other troubles in Europe of the seventeenth and early eighteenth centuries; (3) the Napoleonic times and its 
great advance; (4) 1850 with its revolutions or attempted revolutions, and (5) the last twenty years has been a time of great unsettlement and difficulty; where we are going now, I do not know. I expect we are in the stodgy period, but in forty or fifty years we may have a world cataclysm which will stimulate people afresh."

A general survey of the literature on biology of the past thirty years demonstrates that the earliest investigators by no means always had enough facts at hand on which to build their speculations, but one may add that such lack of facts by no means lessened the output of speculation. However, an amount of good work was done, so that one really did obtain more exact anatomical and physiological data, especially in cytology and neurology. Much of the advance in the latter subject was due to the excellent work of the Spaniard, Ramon y Cajal. Considerable promotion and dissemination of biological knowledge through various periodicals then took place, which, in turn, stimulated general interest enough so that provision was made for specially equipped laboratories.

But merely extending knowledge a step further is not developing science. Breeding homing pigeons that could cover a given space with ever-increasing rapidity did not give us the laws of telegraphy, nor did breeding faster horses bring us the steam locomotive. The so-called improvements of the microscope pertain to improving the stands that hold the lenses. Until a new principle of optics is discovered, the microscope remains what it is. 
One can say of all other fields of work what the late E. W. Scripps said of the ocean: "Why, of course, everything anybody can learn by investigating the ocean and the organisms that live in it will be useful to somebody in some way, some time." But the real advance in science does not come from merely extending what we have, but very often from uncovering a slightly hidden something that we are permitted to use, and to work out some general law or principle from this. The problem is not, as Morgan says, "to discover how many kinds of structures exist, but whether there are common principles that run through them all. If there are no such principles, then we are indeed headed toward chaos."

Applying this thought to his particular work, he continues:

"Although we have not gone very far in our analysis, there is encouragement to go on. If one takes the cell division in all its diversity, we shall not get very far by studying all the many variations resulting from slight differences in the structure of eggs of every species, but we shall really have succeeded in accomplishing something worth while if we find a few simple physical principles involved in that cell division."

And so, too, one must not place credit for any given finding in the wrong place. As already mentioned, several writers have pointed out that chattel slavery was quite necessary in one state of civilization if men were to make any progress and have any assurance of even an imme- 
diate success in their varied efforts. Then, too, it was not abolished because humanitarianism abhorred it, but because another type of civilization was brought about by the invention of the steam engine, which made it possible to sustain civilization without slavery. So, too, modern democracy did not evolve from any interest in the brotherhood of man, but because discovery and exploration opened up entirely new channels into which men's lives could flow and lead an independent and self-reliant existence.

Now let us examine the biological literature and the letters received to see what the biological world considers important. One is struck immediately by the practical agreement of the biologists of all nations as to what is important and what has been done, during the past quarter of a century, that is of lasting value.

One finds that after almost a half century of experimentation with just one idea in mind - that of finding new angles by which to demonstrate evolution - a sigh of relief went up that other fields had finally been opened. Yet, paradoxical as it may seem, the finding of the very factors which opened new fields had its rise in the discovery, or rather rediscovery, of a piece of work which, in turn, was the cause of producing another theory of evolution; namely, De Vries' theory of mutation. The rediscovery and verification came about, simultaneously, by De Vries in Holland, Correns in Germany, and Tschermak in Austria, and consisted in making known the outstanding work, by patient experiments, of Johan Gregor 
Mendel. Mendel's work was actually done in a preceding generation, but as it remained unknown until our own, and as it has exercised the profoundest influence on all biological work since 1900, it deserves a place in this survey.

Mendel pointed out that definite numerical results were to be obtained in crossing peas, which he explained by two simple hypotheses - that of segregation and that of independent assortment.

The first of these is now accepted as a "law" having a very wide application. All later discoveries in the field of heredity and genetics rest upon that law. It is, as Morgan says, "a broad generalization based on numerical data, and allows us to predict with accuracy the outcome of a given solution."

Practically all those biologists whose opinion was asked, were unanimous in putting the experimental work on genetics and heredity in the foremost rank of this generation's achievement.

Mendel's second hypothesis applied only within certain limits that can be accurately stated, but both hypotheses hold very definitely for the cases he studied and for characters of the majority of plants and animals studied since then. However, much knowledge has been added in the way of additional facts, so that we now speak of a "linking" and a "crossing over" of certain characters, and with such equipment added, we apply the laws over a much wider field than Mendel did or could.

Much of the difficulty of early workers in any new field 
is that they are unable to formulate a question so as to get an intelligent answer, and much of the objection and faultfinding regarding Mendelism is probably due to this same fact.

Any new idea thrown into the biological arena would not only cause great numbers of men to follow experimentally the lead thus given, but the lesser leaders would be inclined to break into new paths, also, though usually into closely related fields. So we find papers on genetics and heredity with emphasis on variation appearing one after another, and almost simultaneously, others on behavior and physiology. This work on physiology concerned itself primarily with the reactions of mature organs, and did excellent work for "medicine." But not long afterward others drove the problem further back, and the question of how the organism arose in the first place, was given a niche in the gallery of experimentation. However, this beginning of embryology was largely descriptive, accounts being written merely of what was seen. From this descriptive work, in turn, real experimental embryology was born. Now, men such as William Roux and Hans Driesch, began destroying or removing parts of the early embryo to ascertain what would happen.

Roux's single pioneer experiment of note consisted in killing one of the first two cells of the dividing egg of a frog. The remaining half produced only a half embryo. Driesch, on the other hand, found that with one-half egg 
of a sea urchin destroyed, the remaining half developed into an entire organism. Driesch finally showed that the apparent difficulty lay in the physics of the various eggs used for the experiment. In some cases the usual method of egg division caused one portion to be heavier than another and thus to sink into the surrounding nourishment. When the heavier part was removed, the lighter portion received but little or no nourishment, and, consequently, could not develop. If, however, one used an egg such as that of the sea urchin or even of the frog, and placed it so that nourishment was forthcoming, then each portion of the egg would result in a completely formed, but often somewhat smaller, animal.

Driesch finally came to the conclusion that to him, at least, there was always something over and above what the laboratory could find in the development of a complete organism from such separate parts. He and his followers, therefore, took the stand that satisfactory explanations are more likely to come from an investigation of the essence of life than from any purely embryological and physiological experimentation in the laboratory.

Here was a parting of the ways. Many sought to retrace their steps and to start anew. Thus some became interested in behavior, and from behavior of the entire higher organisms, or parts of those organisms, there was the inevitable tendency to go farther and farther back. If all life was but the working out of actions and reactions of 
masses of cells, and cells, in turn, were composed of protoplasm, it was but logical that one should study protoplasm. This was not only a fruitful field for an analysis both physically and chemically of the substance of protoplasm itself, but of the behavior of the single-celled plants and animals, which, being actual living organisms, must have within their single cell the answer to the riddle of life.

Physics had won first place in the sciences for four reasons: (1) it accepted the uniformity of nature, (2) it insisted upon exact measurements, (3) it concentrated attention on the regularities that underlie the complexities of phenomena as they appear to us, and (4) it emphasized the importance of crucial experiments.

It was but natural that physiology should try to do with organs what physics did with inanimate material. Thus the study of mere reactions came into being, so that first we wanted to find out the actual chemical make-up of the material with which we were working, and then how it would react to all manner of stimuli as a whole or when certain portions were eliminated. From the grosser experiments, there was a resort to finer ones, and here a single organism was taken and subjected to all manner of "indignities" to see how this particular thing would react under very particular and definite excitations. And here again, biological workers landed in the same type of cul-de-sac in which Driesch had landed.

As J. Arthur Thomson says, "The chemical-physical 
formulations do not actually describe what we see and know. If complete, they would afford a ledger of all the chemical and physical transactions that go on in the body, but that would not describe the organisms' apparently unique qualities as an integrated living individuality, such as the power of enregistering its experiences within itself so that subsequent behavior is influenced. As science is at present, it is necessary to use special biological categories describing the life of the organism - notably its growing, reproducing, developing, varying, endeavoring. For isolated transactions in corners of the body, the chemicalphysical description may suffice, but not at present for any thing like behavior."

Let us retrace our steps for the moment to the birthday of a single little fruit fly in 1910, which happened to be born with white eyes. We find this seemingly insignificant animal the chief factor in furnishing an impetus toward a study of heredity and genetics, which has brought forth what many biologists consider the nearest approach to the solution of any biological problem yet presented.

The impetus this solitary fruit fly gave to the study of heredity and genetics, has brought us to the belief that each chromosome is made up, in turn, of a chain of separate particles which we call "genes," because it seems that they are the very basis on which the genealogy of the individual rests.

Maybe each chromosone has thousands of these genes, and probably no two are alike. The individual plant or 
animal is the product of the activity of all the genes together, while heredity is the result of the shuffling of these genes in each generation.

Quoting T. H. Morgan, who is the outstanding American in this field of work:

"In several plants and animals we can refer these genes to particular chromosomes, and in one animal at least, about four hundred genes have been placed. On the assumption of their relative positions with respect to one another, we can predict what the numerical results will be in inheritance for some four hundred different characters. The theory justifies itself in that it allows one to predict the outcome in terms of numbers for all these four hundred characters whose genes have been located.

"The genes divide when the chromosomes divide, and collectively their division is what we see when each chromosomal rod splits throughout its length. It is the genes that come together with extraordinary precision, which implies probably that we are dealing with events of a molecular order. We can go no further until physics has furnished us with a key to unlock these extraordinary events."

Boveri's work on the mechanics of cytology must not be left unmentioned at this point.

So far we have discussed the work on cytology, genetics, and heredity, embryology and regeneration, and physiology with its subheadings of physics and chemistry. One should not forget the exceptionally interesting and valuable work on tissue culture outside the body of the indi- 
vidual in which they originally grew, done by Ross G. Harrison and Alexis Carrel. These men were able to take individual cells and groups of cells and keep them alive, in apparently good health, quite outside of their usual habitat.

The work on the possibility of artificial parthenogenesis by Yves Delage and Jacques Loeb also belongs in this field. A mere pricking of the frog's egg with the point of a glass or platinum needle, and then washing the egg in blood, will produce fatherless frogs. In other cases, a chemical or physical change of the water in which the eggs are placed will cause unfertile eggs to develop.

Baltzer's work with the green worm of the Mediterranean and the North Seas seems to show that sex may be determined by either environment or food, or a combination of both, for he was able to produce intermediate sexes by merely shaking from their usual position, those which would ordinarily have become males, and forcing them to grow in a foreign medium.

The work of $\mathrm{H}$. S. Jennings on the behavior of the lower organisms seems to demonstrate some "purposive behavior" even in animals of a very low level. Such experimental work as having a brainless starfish attack and conquer an equally brainless, but none the less formidable, sea urchin may throw much light on some future experimental psychology.

Closely akin to this type of experimentation is that of the various "tropisms" - the name given to those "engrained constitutional obligations to adjust the body so 
that the two sides, it may be the two eyes, ears, or nostrils, are equally stimulated" to secure a physiological equilibrium.

"Thus the young eel or elver goes straight upstream, the male mosquito finds the buzzing female, and the moth flies into the unnatural stimulus of the candle. Somewhat higher is the persistent way in which newly hatched loggerhead turtles make for the open horizon, as Professor G. H. Parker has shown, which usually and happily means finding the sea."

Finally, one may add the work done in comparative psychology, and the attempt to show what effect the "mental" has had in determining the path of evolution.

In this connection, also, should be mentioned the work of Robert Chambers in developing a technique of microscopic dissection, which opens up a field yet unexplored, and that of Professor Pregl of Graz, who has done outstanding work on the ultramicroscope and developed new methods in microanalysis.

From an agricultural point of view, a valuable answer has been found for such questions as "How can we, even by an importation of many different types of plants and animals, each susceptible to differences in temperature, clime, soil, moisture, and disease, keep that particular balance in nature which modern transportation is continually upsetting, by importing with such plants and animals those particular parasites, which will keep or again bring back that particular balance in nature so much needed," by the workers in applied entomology, well represented 
by such men as L. O. Howard, who furnished some most stimulating answers.

In biochemistry, the paper of Hopkins and Willcock, Amino Acids in Metabolism, in 1907, foreshadowed the very important discovery of vitamins. It showed that some accessory food factors in the growth of an organism cannot be chemically analyzed.

Indirectly correlated with this field in its scientific aspects is the work of Dr. Allen on the Artificial Culture of Marine Plankton Organisms. His study showed that organisms require, when developed artificially, chemically pure solutions to be sensitized by natural waters before they can live and breed in them.

The work on vitamins, the discovery of their production in relation with sunlight, etc., is of great concern not only to the health of man, but of considerable practical utility in connection with the production of his food supplies.

Under biochemistry one should certainly mention what J. Arthur Thomson considers one of the great milestones in biology - the discovery of a "glutathione" by Sir F. Gowland Hopkins in 1921. This is an organic substance widely distributed in plant and animal cells which acts as an "oxygen transporter," that is, as an intermediary between the oxygen of the air and the food materials of the tissues. Its biological importance is due to the fact that "this transporter and liberator of oxygen accounts for the energy-yielding combustions that take place at a low temperature within the living cell. It explains how the cell burns and yet is not consumed." 
D. Keilin's discovery of the cell pigment "cytochrome," which has something to do with the control of oxygen within the cell also should be mentioned.

Finally, Professor Baly's discovery of artificial photosynthesis should not be forgotten. Baly's work made possible the forming of organic compounds, such as formaldehyde, from water and carbon dioxide, which process, in turn, formed sugar.

Nearly all biologists placed the work on endocrines among the most notable achievements of this generation. Thomson says of these powerful factors in the lives of all organisms, that they are chemical messengers which are like "keys that open certain doors and close others, and they exert a regulative action on many of the functions of the body, securing their orchestration or correlation."

The discovery of this chemical integration "has changed the whole face of physiology. Biologically regarded, the hormones, such as adrenalin and thyroxin, enable the biologist to understand not only everyday events such as the cat's hair standing on end before the intruding dog, but the changes that come in adolescence when hormones from the reproductive organs saturate throughout the body, and activate the growth of the stag's antlers, the swelling of the frog's first finger, and scores of other adolescent novelties."

The most spectacular work in preventive medicine, which really belongs in this century, because real effective proof of its working out was not forthcoming until 1900 or thereafter, is that of the discovery of how malaria and 
yellow fever are carried, followed by the exceptionally effective methods used in applying this knowledge in those regions where the disease was always a source of dread and death. A Latin American, Carlos Finlay, was really the pioneer in yellow-fever work, and your own Oswaldo Cruz, saved the lives of untold millions by his intelligent application of the principles that Finlay and Reed discovered.

One might add the discovery of diphtheritic antitoxin to the list of outstanding medical discoveries that were ushered in at the moment when the nineteenth century was giving way to the twentieth. No longer ago than 1893, where records were kept, some 58 out of every 100 diphtheria cases ended in death. After 1895, with the discovery of antitoxin, there were less than four deaths in every hundred diphtheria cases, provided, of course, that the antitoxin was injected shortly after the onset of the disease.

With typhoid fever, the change in fatalities is even more amazing. ${ }^{10}$ During the Boer War, (1899-1900), with only approximately 208,000 soldiers engaged, there were 57,683 cases of typhoid with 8,022 deaths, while only 7,781 men were actually killed in battle.

Only sixteen years later, on the great Western Front during the World War, with approximately 1,300,000 British, there were in all only 7,500 typhoid cases of which 266 resulted in death. This typhoid comparison is of especial interest because the French did not use the methods employed by the English during the first sixteen 
months of the war, with the result that their reports show 96,000 cases of the disease, of which 12,000 resulted fatally.

One should mention here, also, the discovery of insulin by Banting, which is of far-reaching medical import. The story of this piece of research, which ultimately culminated in the discovery of insulin, according to a correspondent, had "a long background of trials as between the known facts of sugar reduction in the body, the immediate necessities of diabetic patients, the existence of corrective substances in the pancreas, and above all, the clinical failure of gross pancreatic secretion. It was the idea of utilizing pancreatic material before the normal, external secreting cells had developed in the young, coupled with some highly practical knowledge of domesticated animals, that gave Banting his opportunity."

F. d'Herrelle's discovery of the bacteriophage, the enemy of germs, a "parasite upon a parasite" and not a chemical something, also is considered of possible importance for the future. Then, too, the extremely important and almost exhaustive researches of Maud Slye upon over 50,000 mice, has demonstrated at least one thing in regard to cancer - that both resistance and susceptibility to that dread disease are hereditary in the animals studied.

With this little summary of the outstanding biological work of our own generation, we may pass on to what problems the biologists themselves feel have been actually solved during this period, and try to ascertain 
what they consider the most important problems still unsolved.

All are agreed that no problem has been fully solved, but that, nevertheless, much light has been thrown upon a goud many points of interest which will prove valuable for workers of the future in continuing from where we of this generation have left off.

It may afford the layman an interesting insight into the mind and thought of the biologist to read a letter such as this:

"You ask my opinion as to the most important biological problems of our age! I must confess that I find it utterly difficult to give an exact answer: Any biological problem is of importance, none is superfluous or even of subordinate importance; that is, if you think of biology as a whole and not only as an aid to industry, etc. Biology is a building that needs every one of its stones - if you take any one of them away the entire building will fall into pieces again. Every biological investigation is of equal importance; i.e., if it is not worked out or followed out into caricature. Only history can, in the long run, decide and estimate with certainty the sound kernel of each 'mode' - every 'mode' is bound to be driven into caricature, when its adorers take the last steps into that cul-de-sac, where every mania soon or later comes to an end. Choose whichever instance you will, systematics and classification, phylogeny, cytology, physiology, heredity, etc., you will, in every case, find that students of biology at last put their heads into the cul-de-sac and cannot 
get further until they are pulled out by some other partial discipline. The side path was passed by unheeded, because they could not and cannot look in more than a single direction - most biologists have only small horizons. To every age, the problem or problems will seem to be of greatest importance where some of the great personalities of that special epoch casually are leading others."

More than one writer speaks of the "fads and fancies" which have taken hold in biology at various times, and these men call attention to the fact that we have but to examine the scientific journals to see the successive waves of contributions on tropisms, artificial parthenogenesis, cytology, spermatogenesis, regeneration, genetics, tissue culture, endocrines, etc., which have come and gone. There seems to be some one stimulus for such work, which springs from some particular discovery that promises a way out of the mechanistic dilemma, that is, which promises some light on a mechanistic explanation of living phenomena. Many then start work on a problem and pile up apparently stronger evidence, only to find themselves at sea more than they were before. That particular problem is then dropped, and work is begun on another, followed by the same result. This procedure necessitates intensive work which leads to quick results, and has its advantages, of course, but instead of following the problems out with some degree of finality, it gives up and another fad is followed.

Back of all experimentation, the impetus seems to come 
from a belief that in the physicochemical explanation lies the only mode of approach to an understanding of life itself acceptable to the modern man.

Let us then, at this point, try to find what modern biologists consider the most fundamental problems of the day.

Again there is practical unanimity.

1. The nature of life. That is, does living organic substance differ from the inorganic? While this problem is far from being solved, it seems that the recent work on bacteriophages and the filterable viruses is pushing our horizon to a much lower level.

2. The discovery and constitution of protoplasm, and its manner of operation.

3. The problem of the causes of variation, which may in turn be stated as the mechanism of differentiation and the mechanism of evolution.

4. Cancer research. Cancer is ravaging humanity continuously to a greater extent, and practically nothing is known of either its origin, its control, or its cure.

5. The relation of genetics and environment. Important, because so many human problems are affected by genetics, such as disease, sociology, etc.

6. Disease. Is its predisposition really hereditary or is it environmental? Is any defect really hereditary, or is it induced by environment?

7. Criminality. Is it an heredity defect, or is it environmental in its origin? These are decidedly important human problems. Even immigration is affected by the answer. 
8. So-called superior and inferior peoples or races. Are they really such?

9. Economic entomology. Particularly emphasized because of the growing importance of many species of insects. The interference with the balance of nature converts many insects into potential or actual enemies of man and his products. An enormous amount of work needs to be done in this field.

All agree that the work done on genetics and heredity and in their related fields of physiology and biochemistry has greatly extended man's knowledge of the mechanism of inheritance and the relation of inheritable units to definitive characters, resulting in the development of the organism. They also agree that they have thrown considerable light on sex differences and the determination of sex, while the work on the ductless glands has thrown a light on personality and human biology. But these studies also cause us to withdraw our former idea that heredity was everything and environment nothing.

What has really been demonstrated by this work may be summarized as follows:

1. That heredity is an orderly process, obeying certain very definite laws.

2. That environment is coequal with heredity. What part each plays is still to be solved, that is, in any given instance, something may be the product of environment or of heredity, but the question of which is the more important can be studied only in the individual case.

3. From the philosophical side, that genetics is the 
single experimental criterion of evolution, and hence of biological philosophy. Its findings have, therefore, forced the withdrawal of science from the welter of speculation into which it had fallen, by establishing experimental tests for the various claims. And finally,

4. That genetics permits a better valuation of many problems of disease, of insanity, of feeble-mindedness, and of various individual and social problems.

${ }^{1}$ (1) Biography, History and Bibliography; (2) General Biology; (3) Evolution; (4) Cytology; (5) Genetics; (6) Biometry; (7) Ecology; (8) Animal Behavior; (9) Physiology, Biochemistry, and Biophysics; (10) Colloids, Surface Tension, Permeability, etc.; (11) Enzymes and Catalysts; (12) Electrolytes and Ions; (13) Light and Heat; (14) Electricity, X-Rays, and Radium; (15) Oxidation and Reduction; (16) Methods and Apparatus; (17) Blood and Body Fluids; (18) Nutrition, Metabolism, Growth, etc.; (19) Digestive System and Secretions; (20) Respiration; (21) Endocrinology; (22) Kidney, Urine, etc.; (23) Reproduction and Lactation; (24) Environmental Responses; (25) Sense Organs; (26) Nervous System; (27) Motor Apparatus; (28) Vascular System; (29) Pharmacology; (30) Pathology; (31) Immunology; (32) Filterable Viruses, Bacteriophage, etc.; (33) Parasitology; (34) Bacteriology and other Microbiology; (35) Economic Entomology; (36) Economic Ornithology; (37) Animal Production; (38) Argonomy; (39) Horticulture; (40) Forestry; (41) Pharmacognosy and Pharmaceutical Botany; (42) Systematic Botany; (43) Morphology and Anatomy; (44) Paleobotany and Paleozoölogy; (45) Vertebrate Anatomy, Histology, and Physical Anthropology; (46) Embryology; (47) Systematic Zoölogy.

${ }^{2}$ Minot, C. S., Modern Problems of Biology, 1913.

${ }^{3} \mathrm{Kellogg}$, Vernon L., "On International Biology," Bul. Pan-American Union, December, 1925.

"Science News, "The French Association for the Advancement of Science," Science, August 13, 1926.

"Ritter, Wm. E., "The Australian Meeting of the Pan-Pacific Science Congress," Scicnce, March 28, 1924.

"Morgan, Thomas Hunt, "The Relation of Biology to Physics," Science, March 4, 1927 , p. 219.

"Thomson, J. Arthur, "Biology," Encyclopedia Britannica, (13th Ed.)

\$Morgan, Thomas Hunt, op. cit., p. 216.

'Thomson, J. Arthur, op. cit.

${ }^{10}$ President's Address, Report of the Ninety-Second Meeting of the British Association for the Advancement of Science, 1924. 


\section{CHAPTER III}

\section{A CROSS SECTION OF PRESENT-DAY BIOLOGICAL THOUGHT}

Now we approach the most interesting question of all: In what way, if any, has the work of biologists influenced the life of a people, philosophically, educationally, economically, socially, politically, and religiously?

In our discussion up to this point, we have found a practical unanimity. It is true that individuals have considered some finding, probably just on the borderland where we did not yet know its exact significance, of sufficient worth to be included in a list of matters of note, while others felt that the evidence for its inclusion was not quite sufficient. As a whole, however, there was little difference of opinion, and when there was it was always due to an attempted explanation or interpretation.

Since we shall have to deal with explanations or interpretations in this lecture, one is not astonished to find biologists themselves at considerable variance with one another. In this part of our survey, one runs the entire gamut of possible explanations, from that of the writer who flatly and with decided finality insists that biology, as such, never has, does not now, and never can influence anything or anybody, to the one who insists with the most enthusiastic avowal, that every advance the world has made, is making, or ever can make, must always, in 
the final analysis, rest upon the findings of biology and biologists.

On the positive side we find, from our survey of biological opinion, that the most outstanding and important findings of biology which have influenced mankind are summarized under the following headings:

1. Medicine and general health, especially through the study of parasitology and disease prevention. In this connection, one must not forget the remarkable results obtained in the practical fields of medicine from such studies as those made on malaria, yellow fever, typhoid fever, and diphtheria, to mention only a few.

2. Bacteriological and parasitological findings applied to commercial processes, and insects and plant control, which, in turn, affects the entire food supply of man.

Closely connected with this latter work is that of applied genetics. Here questions like the following find their answers:

"How can we breed those types of plants and animals which will thrive best, and present those characteristics we desire in our own particular region of the world?"

"How can we make disease-resistant plants and animals?"

"How can we make the waste places of the earth become of value to man?"

"How increase the yield of crops?"

"How can biology be brought to advance the work of the agriculturist, the cattle breeder, etc.?" 
Thinking of matters of this kind, Professor Gardiner says :

"Our knowledge of vitamins and their production has undoubtedly changed the lives of people in this country (England) very profoundly; its association with the knowledge of feeding and growth in animals and plants has influenced the development of agriculture on every side."

The effects "are reflected in politics and education. Scientific biology is at the base, and stimulated the development of fisheries not only in Western Europe, but in your own country (United States) as well; the basal work and the stimulators were university men of science, not people paid by the state."

3. The beginning of a so-called human biology in which the developments and findings of comparative psychology assist us toward a better understanding of human relations.

In this regard, Professor G. H. Parker holds that:

"Modern aspects of animal activities in relation with genetics will serve as a basis for understanding human life in a way in which it has never been so completely understood heretofore. The biological attack on this question is probably the most fundamental that has ever been made."

Here one must consider the application of these findings to sociology at large. One of the outstanding questions which confronts us and requires an answer which the biological psychologist alone can give, is: 
"What and why were certain variations and modifications allowed to persist which could not have persisted without some social shield?" Here, too, must be placed those newer findings and interpretations resulting from the study of endocrines and their relation to the emotions. This is a second fundamental problem of human biology, and one which as yet is scarcely understood, but nevertheless is bound to influence most profoundly much of our present and future interpretation of all things psychological and sociological.

4. Organic evolution; a subject mentioned by practically every writer. Professor B. A. Bensley says in this regard:

"I do not believe that the larger effects of biological or other scientific study can be of greater or different consequence in one country than another. I think we would have to admit that organic evolution and its historical setting have made not only the greatest difference to humanity, but also that no other single issue including the entire industrial development of the world, has been so important. Organic evolution ought to have been one of the minor issues - historically the stage was not set that way."

5. To the four preceding headings, Professor Conklin adds a fifth: the noninheritance of acquired characteristics, a biological factor with a vast influence on account of its wide ramifications in almost every walk of life.

On the negative side, we may quote one correspondent who reviews the matter thus: 
"To my mind the greatest achievement of biology, which is at last being realized, is negative: that science, when placed in any sort of straight-jacket (of preconceived theory), leads into blind alleys."

This fact is instanced in the following cases:

1. In embryology, the mistake of interpreting all phenomena of development as ancestral indications is now generally admitted. All this is well shown by the writings of such men as T. H. Morgan, Wheeler, Jennings, Ritter, and a number of others.

2. In genetics, the work of Jennings, Conklin, Morgan, and others has shown that environment and heredity stand on an equal basis. Heredity is not the all-powerful influence formerly taught, and environment nothing. Both are coequal.

3. Physiology cannot achieve results by ignoring anatomy. A structure functions only in relation to an environment (internal or external). Physiology, by disregarding anatomy and ecology has proceeded no whit further from the position Goethe criticized in Faust a hundred years ago with the words,

"Wer will was lebendiges beschreiben

Sucht erst den Geist heraus zu treiben.

Encheiresin naturae nennts die Chemie

Spottet ihrer selbst und weiss nicht wie."

Organisms cannot be understood by studying the anatomy, the environment, or the functions alone. There must be interdependent study. The same writers mentioned above also have written on this matter. 
4. "Mechanistic evolution" is a straight-jacket for experimental work. "Emergent evolution" permits mental freedom. However, if the writers on this theme permit themselves to go on logically, it will drive them directly into the philosophical position of the neoscholastics. Evolution is not an automatic thing, but an intelligently guided phenomenon. One thinks of the names of Lloyd Morgan, Ritter, Lovejoy, and Noble, especially in this regard.

5. Too much time, beginning with Darwinism, has been wasted in useless speculation. Even now, too many biologists are spending time in speculating, instead of applying the experimental facts to their pet theories. Biological philosophy must be fitted to the facts, not facts to preconceived notions. This, too, is being realized by such men as Jennings, Morgan, Wheeler, and a host of others.

6. The line of human descent leads away from the apes, rather than toward them. That our primitive ancestors had a mind, hence intelligence, is revealed by additional human discoveries; wherever man has left traces besides his own bones, those traces show the workings of an intelligence. These same traces show that the "cave man" of popular fancy never existed: the cave man is an extraordinarily intelligent man, endowed with a mind; one who had a religion, believed in a hereafter, honored his dead, had a knowledge of handicrafts, and who practiced various arts (painting, sculpturing, modeling, carving, etc.). Osborn recently remarked in this regard, "Man is the most 
incomprehensible thing of this world; and in man the mind is the most incomprehensible thing of all." There is no transition between him and other animals; even his so-called nearest relatives show not the slightest trace of intelligence.

The intellectual man really seeks philosophical progress. As one correspondent puts it:

"Philosophical progress is the nearest thing to what our nature seems to demand - perhaps one might say an upto-date religion. I would say that all demonstrations, especially geological, paleontological, or in general, truly historical, that will yield facts rather than sympathetic theories, will be important but accessory. Some are tired of evolutionary work, others think the picture is not yet plain enough to satisfy.

"I would, therefore, place in order of importance, first the demonstration of chemical homologies and sequences in living protoplasm. I believe they will provide a counterpart and largely an explanation of the ramifications of morphological modifications. Second, the primary nature of living protoplasm. These two are related, but I think there is no doubt that the sticking point in biological philosophy is the origin of life."

We find the biologist's spirit depressed by the fact that the intellectual phases of scientific progress enter so slowly into the actual life of humanity. Whatever influence biologists may wield on the political, social, and even religious thought of the day seems to come through 
some more or less practical applications, as only that very small, more highly educated portion of the public ever can approach a true conception of the scientific philosophy of the time. As Professor McClung, wistfully puts it:

"At a time when science is proclaimed the chief reliance of organized society in securing perpetuation; when through its ministrations, human life is materially lengthened, made more effective and enjoyable; when the uncertainties of existence, and the terrors of the unknown are yearly being reduced in significance, then we witness the paradox of vicious and unreasoning assaults upon the methods and conclusions of science by legislative enactments to cripple its progress and limit its teaching.

"It would seem from all this that science is in our day and generation, but not of it. This is no doubt largely the fault of scientists who have ever been inclined to become absorbed in their pursuit of knowledge and to manifest little concern with the use that is to be made of it."1

Certainly nothing is added to the intellectual probity and honesty of scientific men, when some of our most important publishing houses print editions of biological texts in which every reference to evolution is deleted, just to please the less intelligent regions of the country. Such a procedure is especially bad when everyone knows that both author and publisher believe things quite dif- 
ferent from what their textbooks imply. If scientists will cast aside what they really believe and are supposed to hold dear, merely to sell a few extra copies of their publications, why should one expect nonscientific minds to believe that science leads to truth?

Peabody has recently said:

"The popular conception of a scientist as a man who works in a laboratory and who uses instruments of precision is as inaccurate as it is superficial, for a scientist is known not by his technical processes, but by his intellectual processes; and the essence of the scientific method of thought is that it proceeds in an orderly manner toward the establishment of a truth."

Yet how far short of that ideal even a most eminent man, in such a supposedly absolute science as mathematics, may fall! Consider the case of $\mathrm{M}$. Michel Chasles, ${ }^{3}$ one of the leading geometricians of his time. Between the years of 1861 and 1870 , he bought more than 27,000 manuscripts forged by a man with meager education, who must have worked many hours daily for long years to complete so many. These manuscripts contained hundreds of letters from Pascal, twenty-seven from Shakespeare, hundreds from Rabelais, many from Newton, Louis XIV, from the Cid, and from Galileo. There were letters from Sappho, Virgil, Cæsar, St. Luke, Plato, Pliny, Alexander the Great, and Pompey. There was even a letter from Cleopatra to Cæsar, a note from Lazarus to Peter and a pleasant little missive from Mary Magdalen to the King of the Burgundians. 
Every one of these letters was written on the same kind of paper (not on parchment), and all were written in French. One can appreciate a nonscientific writer's comment upon this case :

"Remember that these manuscripts were eagerly purchased and their authenticity warmly defended by one of the leading geometricians of his time, and then believe, if you can, that development of the mathematical faculty has anything to do with reasoning power, or even common sense."

When we speak of men still living, or but recently passed away, in whose disciples the fires of emotional desire for credit loom large, matters of importance to the real advancement of science are too often confused with a mere matter of priority, so that, as Metcalf has pointed out, the more valuable work is usually overlooked or forgotten. To this same idea, J. M. Aldrich contributes the following:

"Criticism is usually a generation behind publication, so that the poorest work may stand, as we often see, for twenty or forty years before it is completely revised. Moreover, in North America at least, the ablest men are quite likely to be the very ones to succumb to the higher rewards of administrative and economic work, and so fail to make the contribution of which they are capable."' And finally, in the matter of psychological reaction of scientists, Poincaré has called attention to the comparison of Gallic and Anglo-Saxon genius.

"Characteristic of the one is a feeling for form, for sym- 
metry, for logical completeness, for finality; characteristic of the other is the feeling for substance, development, function, change. For the one, truth lies in the result; for the other, in the process. One is represented by the deductive, the other by the inductive type of mind."

The one type of mind holds that there is a possibility of finding an exact correspondence between the thing itself and our idea of that thing, which means absolute truth insofar as that one idea is concerned at least. The other holds that there is no such thing as absolute truth or falsehood of any theory or observation but, that as scientists, it is our duty to weigh carefully all the chances for truth and error, place each in its proper position, and thus improve the way. Professor Beach, speaking for this group, puts it like this:

"It is important to recognize the fact that scientific laws are not proved by perfect corroboration of measurements. The proof of any law is of negative character. Not even the law of gravitation, nor the law of the conservation of energy is proved by positive demonstration. The probable truth of any proposition is assumed from the inability to disprove it. Whence it follows that there is nothing more fundamental to the correct understanding of the science of physics, or indeed of science in general, than the interpretation of measurements according to the theory of probabilities and a rational discussion of the inherent errors."

While H. B. Torrey, speaking of the influence that 
modern scientific thought has had on philosophy, adds :

"Science has progressed in the biological sciences by abandoning a faith in final causes for a faith in the hypothesis that works, by draining off every stagnant suspicion of ultimateness in explanation, in the light of the conviction - the product of experience - that the ideas that serve us change with our knowledge of object facts."6

And I think that he sums up well the ideas on this matter of the average biologist in the three following paragraphs :

"For one who seeks a basis of criticism for a contribution to science, three obvious tests may be applied.

"1. It may contribute new facts.

"2. It may contribute a formulation of old facts.

" 3 . It may contribute a new idea that, in the presence of facts, may lead to a new point of departure for explorations into the unknown.

"If then, one were to apply these tests to what seem to me to be the two most significant developments in the philosophic thought of today, they might be said to fall, very roughly speaking, under the second and third categories. In the former, might be placed the synthetic philosophy of Spencer, an avowedly scientific philosophy whose essential problem was to formulate the known facts of science in terms of principles of evolution. This stupendous project, remarkable alike for the powers of its author and the wide range of his interests, ended in a 
system of philosophy, into which just enough metaphysics succeeded in creeping to justify the criticism that, in spite of all good intentions, he had not been able to disentangle himself completely from the habits of thought to which his critics were happily accustomed.

"Pragmatism distinguishes itself at once from the synthetic philosophy in that it is nonsystematic. Instead of an interest in a formulated body of knowledge, it appears to possess an insatiable desire to determine practical choices. Given a problem of conduct, the solution unknown; what shall the line of action be? Here one perceives a strictly scientific situation that emphasizes the practical value of the hypothesis. The problem is to find a satisfactory path into a new region. And the answer that pragmatism gives is: trust to luck and your past experience. 'The truth,' says James, 'is the hypothesis that will work.' 'The truth,' says Dewey, if I rightly apprehend him, 'is the hypothesis that you can work with.' There is a suggestion of permanency, of stability, of future significance in the latter phrase that makes it, to my mind, more felicitous. But I do not care to dwell on that point. What comes closer to my purpose is to point out that here is no faith in final causes, here is no suspicion even of that innocuous phantom, the unknowable. Here is no distinction between science and philosophy - if indeed pragmatists are philosophers, in spite of the fact that, in one form or another, they fill several chairs of philosophy now in our universities. Here is a faith that facts will tell their tale - will in- 
evitably condition the movement of ideas, that one's imagination content is derivable from one's effective experience. Here is a philosophy that is working a transformation on the thought of the day. How? By abandoning the search for lofty peaks of final causation, from which to triangulate the universe according to logical necessity; emphasizing ideas that shall not only square with the facts as we find them, but shall create others."

However this may be the attitude of the average biological worker, there is another group, none the less able, whose logic leads them another way.

I cannot help mentioning here a conversation with a scientific surgeon held a year or two ago. A matter of surgical procedure was being discussed. The surgeon admitted the force of his opponent's argument. In fact, he said, "There isn't a flaw in the reasoning. I accept the logic of it, and yet, if this happend to one near and dear to me, I would not follow the dictates of my logic merely to make a logical conclusion come true."

To me it seems that here is the crux of a vast amount of conflict in the scientific world. One man will follow consistently wherever his logic leads him, feeling that he cannot do otherwise; the other feels that every problem is to be judged entirely by itself, without relation to the larger issues of history, philosophy, psychology, logic, in fact, without regard to all that which has made our entire background of education and training what it is.

Professor John Dewey, in sketching the development of the philosophies in various countries, laid heavy stress 
upon the fact that the United States of America had not given sufficient thought to philosophy. ${ }^{7} \mathrm{He}$ added that "as long as we worship science, and are afraid of philosophy, we shall have no great science except a lagging and halting continuation of what is thought and said elsewhere."

We may all be wrong in our interpretations. Let us not forget that in the time of Columbus the ablest men were certain that Columbus was mistaken. A later generation may feel the same toward us. The best we can say in all truthfulness is that while we may be mistaken in everything we now hold dear, yet, one is more likely to be correct more often by following the abler men than one is in following those less able. With this as an interpretative background, let us continue with a report of our findings.

The final question in our discussion is that of the status of the vitalistic and the mechanistic conceptions of life. What do the ablest biologists in the various lands hold regarding these two ways of explaining living organisms?

Before presenting their answers, let us suggest a precaution to the nonphilosophical hearers. A vote can never settle anything as to the actual facts in any given case. All that it can do is to show what the majority hold.

We have seen how proximity to one's own work and to those who think alike causes an exaggeration of emphasis on such work and such thought. Scientists, like other people, are so close to their own work that they are like 
the man who could not see the forest for the trees. A wider outlook, it is true, is discernible in the writings of many who are trying to treat the organism as a whole and not as a mere collection of individual and distinct parts.

Thus, Vernon L. Kellogg8 holds that, no matter how the scientist may look at a thing from a purely physicomechanical point of view, when he sits back in his chair in his own home and views his wife and children, somehow there is a greater gap between their reactions to him and his to them, than his laboratory findings would lead him to believe.

Professor Kellogg thus holds with Balzac, that, regardless of what the laboratory tells us, humanity will never accept the implied ultimate of the alchemist who says to his weeping wife, "Stay, I have decomposed tears. Tears contain a little phosphate of lime, some chloride of soda, some mucus, and some water." Is there nothing more to a tear than this? Will humanity ever be willing to accept that analysis? In all probability it will not. Unless the findings of the laboratory fit in with the findings of humanity as a whole, it will do little good to attempt to force acceptance of them with any degree of finality.

If, as Wm. E. Ritter says, ${ }^{9}$ the golden rule has influenced the actions of mankind, it is mighty poor science which would neglect it in writing the history of mankind. It would be like studying the bee and forgetting to mention one or more of the important traits found. And so, T. D. A. Cockerell very recently laid emphasis upon 
the fact that mechanistic science can never bring out a sense of human values. ${ }^{10}$ One can, of course, always say that science shows that the race must be protected, and that consequently one can work out some scheme of morality and a sense of duty from that angle - that what is best for the race and what is best for posterity should be done. But, doesn't such a scheme only furnish a motive without any obligation? Suppose I care not a whit for the race or for posterity, then why should I hold it a duty to sacrifice even a little convenience for them?

Mankind vaguely reaches out for something positive in the way of an analysis of $d u t y$. Nikolai recognized this in his Biology of War. The entire volume was written, practically just to make the point, that something must furnish an obligation if there is to be any duty. And yet, astonishing as it may seem, after going over every review of this book, in every journal written in English (and there were many reviews), I cannot find a single reviewer even so much as mentioning this very thing, about and for which the book was written.

We seem to find that scientists are of two types: The one insistent upon remaining quite modest and laying emphasis upon how little we know about anything; the other not so modest, who insists upon laying all the emphasis on the great progress that has been made.

Even when we dissect Poincaré's division of types of mind into the Gallic and the Anglo-Saxon, ${ }^{11}$ we find the philosopher Schwegler insisting that the Anglo-Saxon mind is extremely acute, but seldom profound. 
He holds that this latter type of mind can find more and devious ways down which to travel, than any other group, but seldom can it stay at one problem until such problem is plumbed to its very depth.

It matters not whether we accept any of these analyses. It does matter whether or not we know that they are there, and that the men who hold them are just as able as those who hold opinions quite the reverse.

The one type of mind insists upon knowing everything about a subject; the other wants to know the subject itself. Let us illustrate. It is conceivable that one might find a scholar who knew every book and article ever written on friendship; who had taken those who were friends of each other into his psychological laboratory and found how they reacted to each other under all and sundry conditions. In other words, here is a man who knows more than anyone else in the world on what we may call the scholarship of friendship, and yet, it is also conceivable that he himself never has known friendship. Knowing about a thing, and knowing it, are two different things.

The poet who has sung of

"A sense of law and beauty, and a face turned from the clod,

Some call it Evolution and others call it God,"

has really a wider understanding of that thing we call life than have many biologists. For, after all, has he not in these few lines really described life? The law of which he speaks is science, and the beauty he mentions calls forth the idea of ideals, of character, in fact, of all things 
which make us appreciate life to the fullest, whenever and wherever it may be found.

Of these outstanding biologists from whom I have sought opinions, I find but comparatively few who are willing to go on record as out-and-out mechanists. Most of them probably feel as the educated people of the United States feel when prohibition is discussed - that no one with any intelligence can be a "dry" and no one with any decency can be a "wet." So many crimes have been committed in the name of each, that few are willing to align themselves as partisans. Thus it seems to be with Vitalism and Mechanism.

Probably the best summary of those leaning toward the mechanistic side is shown by the statement of one who said "most biological workers are practical mechanists, though they admit that life may be something more than Mechanism." Or, by another phrasing it thus: "they are mechanistic in practice, but agnostic in opinion."

Another adds, "It is always dangerous to make categorical classifications, but a majority of American biologists are not disposed to believe in Vitalism, if by that is meant that there is in living matter some principle entirely different from that found in the organic world; that is to say, some principle entirely outside the range of physics and chemistry; on the other hand, I do not know that these workers would care to be styled "mechanists," because of the rather crude ideas that have come to be associated with the term."

But the opinion of men who stand at the very heights 
in biology, in America and Germany at least, may be summed up in this statement:

"Vitalism and Mechanism seem to be antiquated ways of looking at the problem of organic activity, and will be replaced by more modern views on this subject. The contrast between Vitalism and Mechanism is probably a fictitious one. An irresistible trend of thought and feeling in biology, based on the aggregate of positive results gained in the various subdivisions of technical research will, I am quite sure, bring about the final disappearance of the old conflict between Vitalism and Mechanism with no out-and-out victory for either side.

"This conflict has been due largely to the prevalance in it of a maximum of speculation and a minimum of common sense. That many of the structures and activities of any individual animal are mechanical in the sense that they act to a large extent according to the principles of mechanics is so obvious, that nobody questions it as long as he thinks and speaks as an ordinary mortal. Compare the workings of our own limbs with the working of levers, for instance.

"But even the hard-boiled mechanist never questions (so long as he remains true to himself just as an everyday human being) that the individuals in which these mechanical activities go on are alive - are living; nor does he hesitate to call the activities vital.

"Now, it is not doubtful, as I see the matter, what it is, conceptually, that is working most strongly toward the laying of this old bogy. It is what has been for sev- 
eral decades forcing its way into technical biology under the name "the organismal" or "organismal conception." A highly significant thing that is happening at present in connection with this conception is its almost entirely independent growth in some half dozen subdivisions of the biological realm.

"The reach of the conception with its implications, into the sciences of not-living nature, into psychology, and into the domain of thought which has for many centuries been supposed to belong exclusively to philosophy, is certainly immense, though no one yet can tell exactly how far, or exactly what its effects will be.

"But what some of its most far-reaching consequences are to be is rather definitely foreshadowed. It will bring about a much sharper distinction between materialism and naturalism than has hitherto been grasped.

"Another result closely connected with this will be the recognition that man belongs wholly, i.e., with no aspect of his being excepted, to the realm of nature.

"When the most distinctive characteristics of presentday civilization are viewed in the light of the psychobiological matters touched upon here, I believe it must be concluded that man can never benefit to the full from the combination of his reason with his aesthetic, his ethical, and his religious emotions, until he recognizes these to be part and parcel of himself as a natural being."

And here is another statement:

"The most thoughtful biologists are Vitalistic, or lean strongly toward it. As a matter of fact, some who call 
themselves Mechanists disprove it by their own writings. A substitution of words does not convert the vitalistic phenomenon into a mechanical phenomenon. Several of our outstanding biologists who call themselves Mechanists, are really Vitalists by virtue of the very arguments offered in their writings, which in many instances are mere adaptations of the old scholastic arguments.

"One of the amusing instances of pretended Mechanism is that brought forth in the various articles on Emergent Evolution. This 'selective behavior' of 'mass behavior' referred to in these writings, (though the authors themselves seem to miss this) has presented a new and one of the most powerful arguments for Vitalism as yet discovered; e.g., any drop of water will have the same behavior all the world over, when given identical conditions. One Paramecium, as well as one of many another organism, does not behave precisely alike to all others, even under identical conditions. Many drops of water will still behave alike under the same identical conditions (freezing, boiling); but many Paramecia in a group or mass will behave startlingly different from the single individual. This is also shown in other species, e.g., the hunting of wolves singly and in packs, human beings under control of 'mob psychology,' etc."

The following letter throws some light on why many biologists feel that they must adhere to the laboratory findings exclusively, and not permit themselves to be drawn into philosophical discussions, even if these latter may really be of much greater importance to mankind 
than the mere adding of another isolated fact to an already large store of knowledge. Biologists, as well as all other laboratory workers, know that we can understand each other fairly well when we confine our speech to definite scientific terms, but that we usually differ greatly when we enter into philosophical speculation. Scientists, therefore, have limited themselves to certain physically demonstrable methods.

Thus one biologist writes:

"My own observations of other persons' attitudes tempt me to say that as a rule they refuse to take Vitalism seriously, and I do not know whether this means that they have not thought about the possible limitations of science, or whether, as in so many cases otherwise, they are ultrapractical as an accidental habit of mind.

"I am afraid many of us are more interesting as experimental animals for psychologists to study than as monuments of truth.

"My own view of this question is: 'Science limits itself voluntarily to what is reasonably demonstrable, using a perceptive method with logical extensions.' As scientific individuals, we have as much right to free and easy imagination, superstition, and the like, as anybody else. We avoid these things for the sake of safety and security to our field of knowledge. I would think it almost equally unwarranted to state that either life is mechanism or that life contains a vital element which we do not or possibly cannot know. But science itself is a natural development of the human mind. Physics and chemistry are practical 


\section{experiences, and whatever may be present in life, I am} satisfied that so far these sciences have furnished the only kinds of facts out of which we could get any satisfaction, on the set basis of being perceptively observable, demonstrable, reasonable, commanding of universal respect, or of whatever quality scientific men desire to have as a criterion of truth."

\footnotetext{
${ }^{1}$ McClung, C. E., "The Unity of Life," Science, December 10, 1926.
}

${ }^{2}$ Peabody, F. W., "The Care of the Patient," Journal American Medical Association, March 19, 1927, p. 877.

${ }^{3}$ Pearson, E. L., Books in Black and Red, 1923, pp. 10-11.

"Aldrich, J. M., "The Limitations of Taxonomy," Science, April 22, 1927.

${ }^{5}$ Beach, Frederick E., "On the Study of Physics," Popular Science Monthly, 1904, Vol. 65, p. 61.

'Torrey, H. B., "Modern Scientific Thought and its Influence on Philosophy," Popular Science Monthly, January, 1923.

'International Congress of Philosophy, held at Harvard University, September 13 to $16,1926$.

${ }^{8}$ Kellogg, V. L., "The Biologist Speaks of Life," Atlantic Monthly, Vol. 127, pp. 583-593.

${ }^{9}$ Ritter, Wm. E., "Darwin's Probable Place in Future Biology," Popular Science Monthly, January, 1910.

${ }^{10}$ Cockerell, T. D. A., "Duty of Biology," Science, April 9, 1926.

${ }^{11}$ Probably nowhere can the difference in the temperament of two peoples be shown better than in group reactions of the Anglo-Saxons and the Latins, as shown in the following popular account of understanding and lack of understanding of each other by Duff Cooper, M.P., in a recent issue of Graphic, London:

"The difference between French mobs and English mobs, and between political disputes in the two countries was never more vividly exemplified than during the general strike in England. For ten days England seemed to be on the brink of civil war - the eyes of the world were turned toward us in the expectation of terrible developments - and when it all ended, foreigners could hardly believe that not a single casualty had occurred.

"While it was still in progress, there occurred in Paris some celebration in connection with their national saint, Joan of Arc, an historical figure for whom it might be supposed that even an anarchist could feel nothing but respect. But riots broke out, and in one afternoon loss of life and many casualties occurred.

"Meanwhile the strikers in this country were playing football with the policemen, a phenomenon which so puzzled and therefore exasperated foreigners that they were driven to explaining it by saying that the English were incapable of taking even their own revolutions seriously." 


\section{CHAPTER IV}

\section{PROVOCATIVE BIOLOGICAL THEORIES}

In this closing lecture, it is fitting that we consider those provocative biological ideas and theories which, while they do not fit into the general scheme of our former discussions, are, nevertheless, of great import in understanding not only the incentives of future work in the biological sciences, but in showing us why certain paths of experimentation and discussion have been chosen in preference to others.

These ideas and theories, which are considered of great importance by the outstanding workers of all lands, are: the Organismal Theory, with some of its attempted explanation such as the Organisationcentrum Theory, the Axial Gradient (or Metabolic Gradient) Theory, the Metabolic Theory of Sex, the Theory of Plasmogeny, and the Theory of Emergent Evolution.

The Organismal Theory. The founding of the cell theory by Schleiden and Schwann, followed by the histological work of Bichat, had caused biological workers to look to the individual parts of the organism, and primarily to the cell, as the source of explanation for vital phenomena. From about 1890 on, the older conception of thinking of the organism as a whole again came into its own. The foremost exponents of this Organismal Theory, contrasted with the exponents of the Cell Theory as a 
source of explanation of living organisms, were C. O. Whitman, E. B. Wilson, F. R. Lillie, Jacques Loeb, and more recently, William E. Ritter.

Whitman's The Inadequacy of the Cell-Theory of Development (1893) initiated the newer conception. He says in this essay: "Comparative embryology reminds us at every turn that the organism dominates cell formation, using for the same purpose one, several, or many cells, massing its materials, directing its movements, and shaping its organs, as if cells did not exist, or as if they existed only in complete subordination to its will, if I may so speak." And again, "The fact that physiological unity is not broken by cell boundaries is confirmed in so many ways that it must be accepted as one of the fundamental truths of biology."

E. B. Wilson followed Professor Whitman's lead with his essay on The Mosaic Theory of Development (1893). Then F. R. Lillie in Properties of the Whole (Principle of Unity), a paper on the development of Chaetopterus (1906), a marine worm, brought additional emphasis to this theory as shown by the following extracts from his paper:

"If any radical conclusion from the immense amount of investigation of the elementary phenomena of development be justified, this is: That the cells are subordinate to the organism, which produces them and makes them large or small, of a slow or rapid rate of division, causing them to divide, now in this direction, now in that, and in 
all respects so disposes them that the latent being comes to full expression. The organism is primary, not secondary; it is an individual, not by virtue of the coöperation of countless lesser individualities, but an individual that produces these lesser individualities on which its full expression depends. The persistence of organization is a primary law of embryonic development."

But it was left for William E. Ritter to treat the whole theory in a most comprehensive and exhaustive manner in his two volumes entitled, The Unity of the Organism (1919). I have, therefore, asked Professor Ritter to put into as few words as possible a statement of the theory itself and what actually brought it into being. This is what he says:

"There is no doubt that the theory has been in the world from the time of Aristotle at least. How much longer I do not know. When this Greek pointed out that any object, a couch for example, has certain attributes of its very own and hence cannot be interpreted on the basis of the attributes of any other object, even though these be those of which the object in question is composed, he simply called attention to an item in the mental technique employed by every working naturalist, no matter what his field. It is of prime historic importance, I think, to distinguish between Aristotle the naturalist and Aristotle the metaphysician.

"My own first arresting glimpse of the knowledgegetting principle here involved came, as I recall, from noticing that when the materialists (really elementalists) 
try to live up to their dictum about expressing their knowledge concerning wholes 'in the terms of' the elements of the wholes, they have either to leave out entirely any reference to the attributes of the wholes, or else gratuitously to carry back the attributes of the wholes to the constituent elements. Water, for instance, expressed as the 'oxide of hydrogen' expresses nothing whatever of the attributes of water, and if we try to attach water attributes to the elements, merely for the sake of recognizing in them their ability to make water, not only do we do a purely gratuitous thing, but we involve ourselves in a fog of uncertainty from not knowing anything about how to distribute the water attributes between two constituent gases. This aspect of the problem of wholes and elements has been worked out so thoroughly in so many ways, epistemological, logical, chemical, physico-chemical, biochemical, and statistical, culminating finally in 'emergent evolution' (G. H. Lewes, C. L. Morgan, etc.) on the biological side, and 'organic mechanism' (A. N. Whitehead) on the nonbiological side, that there seems no alternative to our accepting it as basic for all existence to which our knowledge processes have any access.

"For myself, relying as I do on the natural-history mode of philosophizing as a methodological concomitant of the organismal conception, I find it quite satisfactory to define the conception illustratively by calling attention to the fact that all bodies, both living and not living, about which we know anything, furnish evidence that the elements of which they are composed have latent powers, 
which are brought to actuality in no other way than by coming into just those relations which they are in when constituting these bodies. And of all the evidences to this effect, the most conclusive is that furnished by what I myself as a rational and emotional being am able to get from the air, food, and water which I consume.

"It is undoubtedly a great thing that chemistry and physics have confirmed and greatly extended universal experience to the effect that without air, water, and food, growing, playing, and working, feeling, and thinking, in a word, 'living' is impossible. But so long as these sciences tell us nothing, or next to nothing, as to exactly what the portions of external nature that we utilize are doing to enable us to do these things, they have fallen exceedingly far short of fully explaining us to ourselves."

And so, as modern zoölogists are no longer inclined to think of an animal as a system composed of individual minor unities, but think of the entire organism as a real - and complete unity, the point of view resulting has caused experimenters to apply their efforts toward solving the problem of how this unity comes to be what it is. In fact, Professor E. B. Wilson (1923) goes so far as to make the problem of "organization" an ultimate category which is to stand beside that of matter and energy. Subordinate to this general problem of organization is that of control or regulation of the development of the new individual.

Professor Child, speaking of the organized individual, defines individuality as follows: 
"In the first place, the organic individual is alive and, therefore, consists of the complex substances termed in general protoplasm; second, it is more or less definitely limited in size; third, it possesses a more or less definite morphology, a visible form and structure, which is associated in some way with dynamic and primarily chemical activity; fourth, a greater or less degree of order, coördination, correlation, or harmony as it is variously called, is perceptible in the character of its form and structure and in the dynamic activities of its constituent parts. In short, the organic individual appears to be a unity of some sort; its individuality consists primarily in this unity, and the process of individuation is the process of integration of a mere aggregation into a unity, for this unity is not simply the unity of chance aggregation, but one of a very particular kind and highly constant character for each kind of individual."

The problem presented, then, is to try to determine the nature of the unity underlying individuation, which, in turn, has developed into the problem of control or regulation of the potentialities of development; a search, it might be called, for some principle of regulation in a growing organism.

The Organisationcentrum Theory. Hans Spemann (1922-24) has brought forth a suggestive idea in this field, which the Germans call the Organisationcentrum Theory, a theory resulting from the study of early stages of organic development. Spemann's experiments, cover- 
ing a period of some twenty years, were performed on the developing newt. He found, as in other embryonic animal development, that after the fertilized egg has divided into a number of undifferentiated cells, the upper cells grow down and cover the lower. A circular zone of downgrowth is thus formed, marked by a definite rim or lip. This down-growth begins at one point of the circle (on what is to become the dorsal portion of the embryo) and spreads round, gradually, to complete the circle. This first active region is called the "dorsal lip." Spemann's reasoning led him to believe there was some causal relation between this dorsal lip and the beginning of differentiation among the various cells.

In order to demonstrate his theory, he worked out an interesting technique by which he transplanted a small portion of the dorsal lip into some abnormal position in another developing embryo. The result bore out his supposition, for not only did the animal which had the graft made upon it develop its own set of normal organs, but in addition, it developed a second set in relation to the graft.

Spemann concluded that the portion transplanted had some inherent potentiality of growth which had thus formed what might be called a "secondary embryo." $\mathrm{He}$ again put his conclusion to the test by transplanting a portion of the dorsal lip of an animal which had considerable pigment in it to one which had none, so that the growth of the two tissues could be observed distinctly. 
And again he found his conclusions substantiated by his experiments, for not only did this transplanted portion of the dorsal lip cause a similar growth in an animal of another species, but strangest of all, the new "secondary embryo" was made up of the tissue of the animal to which the graft had been transplanted and not of the tissue of the graft.

The grafted portion of the dorsal lip, therefore, is thought of as an inducer of growth and differentiation of the tissues in which it is placed or among which it is found. This differentiation is supposed to be determined by and controlled by enzymelike secretions, not so much from the individual cells as from certain groups of cells. It is to these groups that the name of Organisationcentra has been given.

The Axial Gradient Theory. It seems that the Germanic peoples have been more influenced by the Organisationcentrum idea, while biological workers in England and a few Americans have found in Child's Axial Gradient Theory a source of new paths down which to direct their experimental energies.

The hold that Child's theory (1915) has taken on some workers, may be gauged by the fact that Professor F. W. Gamble, in his presidential address before the zoölogical section of the British Association for the Advancement of Science in 1924, not only made this theory the main thesis of his address, but held that "no more fertilizing biological idea has been disseminated in the last ten years 
than Child's hypothesis of metabolic gradients. It has captured the imagination of the younger generation of zoölogists, and is exercising an increasing influence upon them."

To understand the theory, it is essential to know some of the observations which led to its formulation. In anesthetizing animals, the head region is always more susceptible to a retardation of metabolic activity than parts some distance from it. When an animal is killed by high concentrations of anesthetics, the head always dies first. In regeneration experiments, where a flatworm, for example, is cut transversely into many pieces, practically all of the cut pieces, with the exception of the head, will grow a new head from the anterior end. This shows that each cut piece had the potentiality of developing one or more heads, but was prevented, while it was part of the whole, by the inhibitory and regulative action of the original head.

From these and many other experiments, scientists have accepted as a fact that not only are the rate and the intensity of chemical changes which take place in a growing, living thing different in different parts of the body, being greatest in the head region and gradually becoming less as the distance from the head region becomes greater, but that the head region dominates the rest of the body. That the latter part of this statement is true is demonstrated by such experiments as the following. A piece of tissue quite foreign to another struc- 
ture, such as a piece of embryonic kidney, is grafted into muscle tissue or skin tissue, and, under the regulatory power of the nerve fibers connected with the central nervous system, with its main seat in the head region, such tissue becomes like that into which it is grafted. In the flatworm, Microstomum, as the animal grows older, the head region loses the dominance it formerly exercised, and a new brain and eyes form about halfway down the body. This, nevertheless, is still under regulatory control of the original head region until it breaks away to become a new individual. The sway of influence of this regulatory control seems to follow the track of the nervous system, diminishing with the length of the cords, or distance from the dominant region. The gradation of the influence of the "head" on the "body" according to distance, Child calls the "metabolic gradient." Therefore, as organisms with a well-defined individuality are always organized about one, or at most a few, broad lines or axes, the supposition that such metabolic gradients determine the nature of the individual has come to be called the Axial Gradient Theory. As a corollary, it is stated that as a central nervous system always forms, if the animal develops far enough, it is to be concluded that the nervous system is the final expression, both in arrangement and in mode of action, of the system of metabolic gradients.

Two factors really should be considered in this theory: (1) that the head is a more or less independent unity; and (2) that the control which the head exercises over 
the rate and intensity of metabolism causes the structural and chemical correlation of the rest of the body. From these deductions, in turn, two further points should be noted: (1) that as each part of the lower animals, as well as the early (embryonic) cells and tissues of higher animals, have the potentiality of becoming what any other cell or tissue does become, the growth action of such parts is always positive; while (2) the head region in its exercise of an inhibitory, coördinative, and regulative action is negative. In criticism of the theory, one may quote G. H. Parker, of Harvard University, who, in leading the discussion of the subject in 1924, at Toronto, called attention to the fact that even before Child had brought forth his evidence for the Axial Gradient Theory, most biological workers had already observed enough similar results from their embryological work to agree with Child on his statements of fact, but that the theory has given no further information than was already known about why anything does what it does.

The Metabolic Theory of Sex. Another metabolic theory of note is that commonly called the Goldschmidt Theory (1923). At the moment there is a dispute between the followers of Riddle and Goldschmidt as to who has the prior claim for its promulgation. All biological workers are familiar with Morgan's work demonstrating that the so-called sex chromosomes are the determiners of sex. Morgan's explanation is a qualitative one. Goldschmidt has devised a quantitative theory, sometimes called the 
"metabolic theory of sex." In this theory, sex is determined by the rate or level at which metabolism takes place in the embryo. The theory takes no account of metabolism as such, but simply of the rate of metabolism. One may probably best suggest the causes which brought this theory into existence under the following four heads: (1) Dr. Riddle, of Cold Spring Harbor, performed a number of experiments with pigeon eggs some years ago which well exemplified this metabolic theory. The pigeon lays two eggs, the first one laid always developing into a male, while the second develops into a female. Riddle carefully analyzed the eggs and found that the maleproducing egg not only contained less stored food than the female-producing egg, but that it also contained more water and, as a consequence, such eggs had a higher rate of metabolism and a higher oxydizing capacity than the female-producing egg. (2) Dr. Whitney performed experiments with a rotifer, Hydratina senta, which animal lays two kinds of eggs, large ones, which develop parthenogenetically into females, and small eggs, which develop parthenogenetically into males. It was observed that when this rotifer was fed green flagellates, it laid small eggs, whereas when it was fed colorless flagellates it laid large eggs. (3) Dr. R. Hertwig had kept eggs of frogs for quite a time before fertilizing them. They thus became overfilled with water before fertilization. A predominance of males resulted. Miss Helen King, of the Wistar Institute, performed a somewhat similar experiment on the 
eggs of toads. She kept them away from water, however. These eggs, therefore, contained very little water before fertilization and a predominance of females resulted from her experiments. (4) Goldschmidt came to the conclusion that certain substances in the fertilized ovum produce the two sexes, and that these substances influence the rate of metabolism. He calls the substance which produces maleness Andrase, and that which produces femaleness, Gynase. Goldschmidt's principal experiments consisted in crossing German and Japanese races of moths. Sometimes he got males and sometimes all females. At other times, he was able to obtain all intermediary stages; this, of course, refers only to so-called secondary sexual characteristics.

One may summarize the differences between the chromosome theory and the metabolic theory thus:

Chromosome Theory

Sex is determined at fertilization.

Sex is fixed.

Cause of sex lies in the chromosome mechanism.

\section{Metabolic Theory}

Sex is determined at an early stage in the embryo.

Sex can be modified.

Cause of sex lies in the metabolic rate.

If I understand Goldschmidt correctly, he holds that in the fertilized egg, after maturation, determiners are always present in the chromosomes for both characters, maleness and femaleness, blackness and whiteness, or whatever the opposing characters from the two parents 
may be. If, for example, a fertilized egg shows an $\mathrm{X}$ chromosome, which, we know from previous experimentation, causes femaleness, a chromosome bearing the determiner for maleness also is present in that same fertilized egg. He holds this statement to be true even though that chromosome may not yet have been discovered, and it is the metabolic struggle between the two which determines the sex as well as all other characteristics of the individual. If the metabolic rate of the $\mathrm{X}$ chromosome is 100 per cent, then a 100 per cent male will result, while, if the metabolic rate of the $\mathrm{X}$ chromosome is but 90 per cent, then the metabolic rate of the opposing chromosome (which we may not yet have discovered) is, of course, 10 per cent, resulting in a creature not 100 per cent male. Such a creature, although a male, will have some female characteristics. The theory holds thus, that such variation in the rate of metabolism may continue to a point where the rate may approximate a 50-50 level. Since, however, sex has but two alternatives, one cannot obtain a perfect 50-50-level individual. In characteristics aside from sex, such a percentage may be possible. The theory really seems to explain many of the intersexual stages, and may furnish an explanation of those characteristics which do not seem to obey the Mendelian law of dominance.

The Theory of Plasmogeny. A. L. Herrera, of Mexico (1921), not satisfied with seeking a unity in the realm of living things, has attempted to find a broader unity un- 
derlying both the organic and inorganic worlds. He believes life to be "infinite movement." $\mathrm{He}$ has succeeded in making what he calls artificial Amoeba and Colpodia - really tiny oil droplets which, when placed in other liquid media, simulate amoeboid and colpodic movements.

But, as Professor Buchanan says, in criticism of all models from which theories of life are adduced, "Caution must be observed in accepting theories of the organism derived from the behavior of models, for in attempting to isolate a single process in this manner, the controls and correlations that distinguish the living from the nonliving are lost. Obviously, the value of any theory, derived from the behavior of a model, depends on the extent of resemblance between the behavior of the nonliving system and the facts and characteristics of the process of the living organism which it purports to simulate." 1

As every laboratory man well knows, living things are, in their physical relations, subject to all the physical laws of nonliving things, so that osmosis, surface tension, temperature, light, heat, and a host of other physical laws are just as operative on living organisms as they are in the nonliving world. It would seem, therefore, that Herrera has given us but another example of how we can make some nonliving substances act quite as though they were living substances, but are we not here obtaining only another "How"? The eternal "Why" of living reactions 
is as much in the dark as ever, as is also the philosophical question of "Why" the laws are what they are.

The Theory of Emergent Evolution. The preceding theories are the work of laboratory men philosophizing on their respective experimental findings. Now we come to the work of a philosopher who attempts to bring order out of chaos in the laboratory world. Only one who has spent a lifetime in the study of fundamental problems confronting man in all its modern aspects, philosophical, psychological, and biological, and who at the same time is familiar with laboratory findings, could hope to bring about a valid synthesis and to work that synthesis out as a unified whole. C. Lloyd Morgan, encouraged by Huxley in the problem he had set for himself a half century ago, has built up his theory of Emergent Evolution in such a way that it has made converts of the greater part of the foremost American biologists, and they look to this theory as the solvent of both mechanistic and vitalistic difficulties.

Beginning with the organism, it was noted that a combination of elements forming such organism not infrequently brought forth a totally different set of attributes at different times under apparently the same external conditions. In other words, something not previously known to be there had emerged. The newly emerged attribute was potentially there, of course, but Professor Morgan (1923) set himself to explain how this emergence occurs.

Two fundamental ideas have been emphasized for a 
long time in biological experimentation: (1) analysis of the environment, and (2) the study of the physics and chemistry of the substances of living things. To these we have now added (3) the physical arrangements of both gross and minute materials in the organisms. At the moment, therefore, we find many of our biological leaders emphasizing not only the arrangement, but the varieties of arrangement and the grouping of the arrangements in the organism.

H. S. Jennings has probably written most satisfactorily on the factors confronting us in attempting explanations, as well as on some of the more outstanding problems that biologists are attempting to solve. We here follow his reasoning though not his wording: ${ }^{2}$

As the properties of atoms depend upon the arrangement of electrons, that of molecules upon the arrangement of atoms, and that of crystals upon the arrangement of molecules, a great extension of all these arrangements is contained in the organism. Here the arrangements have become quite complex and differentiated, forming the visible as well as the invisible parts of the whole. As one passes from one species to another, there is an almost infinite variety of such arrangements. One might call some of them "systems of structures," and consequently, the way an organism responds to a stimulus or an experiment of any kind will depend upon its system of these diverse arrangements.

From an acceptance of such facts, it follows that a 
knowledge and control of the environmental agents impinging upon such organisms, or a mere understanding of the physics and chemistry of the separate substances of which they are composed, can never suffice to bring about a real understanding of what it all means. "The same materials, under action of the same agents, respond in most diverse ways, depending on how the materials are arranged."

Changes of organization take place when the developing organism is subjected to special or unusual conditions, such as the growing of a head in place of a tail. One might expect to find here, then, the secret of biology, as such changes may take place in the grosser as well as the more minute details of organization. But such changes all disappear with the individuals in which they appear. They are not carried on to their respective offspring. Consequently, these things cannot account for the permanent differences of systems found among organisms, and it is just the permanent and hereditary diversities which form the deepest problem of biology.

Since all organisms are but protoplasmic substances, why is it that some are different from others? How, and according to what rules, have these changes occurred? What is the environment in a given case, and what effect does it produce on the organism? What are the physics and the chemistry of the diverse substances of the organism? How are the diverse substances arranged? How combined into systems? What diversity do these systems, 
in turn, form in the various organisms? How do such systems then respond diversely to the same environment and experiment? How does it happen that organisms are diverse systems of structures and functions to begin with? What are the laws underlying the production of these diversities? Why is the same diversity of characters produced in two ways - one by environment and the other by gene differences?

And above all this there is the mystery, not of a part or of any one part of the organism, but pervading the whole - the operation of selective elimination with its complement - selective persistence.

For "in our experimental material, many diverse combinations are formed, diverse chemicals, diverse motions, diverse genes, diverse systems. Experimental conditions cause the elimination of some of these; others persist. At the end, the material before us has changed. Our experimental agent appears to have worked a transformation; in fact, it has worked only an elimination."

Failure to take these facts into account is the cause of much fruitless speculation and discussion.

"Stock is subjected to given environment. After a few generations, it is found changed; the change is inherited even upon the restoration to the usual environment. Behold! We have discovered the inheritance of acquired characters. And then selective elimination is found lurking beneath the surface, and we know not what we have discovered." 
We must keep our eyes open eternally for the part that selective elimination plays in the most fundamental of biological problems - the formation and transformation of biological systems - "for here it plays the master rôle."

\footnotetext{
'Buchanan, J. William, "Some Limitations of Warburg's Theory of the Rôle of Iron in Respiration," Scicnce, Sept. 9, 1927, p. 238.

2Jennings, H. S., "Biology and Experimentation," Science, July 30, 1926, pp. 97-105.
} 


\section{CHAPTER V}

\section{OUTSTANDING BIOLOGICAL WORK AND WORKERS}

In a discussion of the theme National Trends in Biol$o g y$, undertaken in this little volume, it is thought advisable to devote the final chapter to a summary along national lines. This will make the work of each nation more readily accessible to those who seek an extension of knowledge regarding the individuals and the work mentioned.

No attempt has been made to have this list all-inclusive. It serves, however, to present a very fair estimate of the exceptionally noteworthy biological workers of the various lands, inasmuch as the names and the workers are judged important by those of their own lands most eminently fitted to pass judgment - the ablest and bestknown biological workers themselves, who best know the value and influence of the work of their own countrymen.

The arrangement of the four divisions, The Americas, Europe, Asia, and Australia and New Zealand, have seemed the most logical for the purpose intended.

\section{The Americas \\ CANADA}

Canadians consider as the most noteworthy movements in their country:

The coöperative development by the Canadian universities of economic fisheries research, including the forma- 
tion of the Biological Board of Canada and the establishment of marine laboratories, as well as the research fostered, first in marine, and later in fresh-water biology.

Canadians whose work is stressed are:

1. Frederick G. Banting, and (2) John J. R. MacLeod for their discovery of insulin, which brought them the Nobel Prize for medicine in 1923;

3. R. Ruggles Gates, who successfully demonstrated the correlation between chromosome peculiarities and specific characters; and

4. Charles Edward Saunders, who worked so successfully in developing Marquis wheat, which has proved of tremendous economic value to Canada.

\section{The United States of America}

Here the most noteworthy movements mentioned were:

1. The establishment of an International Health Board, which draws its funds exclusively from the Rockefeller Foundation, and which contributed, in the elevenyear period of 1913--1923, three and a quarter million dollars to international health work, and had, in 1924, fourteen expert fieldworkers in South and Central America. It also supports on a fellowship basis, ten South and Central American students of public health in universities and schools of public health in the United States. The most sensational result of this coöperative work is "the now almost complete stamping out of yellow fever in the western hemisphere. It is only a matter of further close 
coöperation during a few years, when this dread disease which formerly ravaged the peoples of North and Central and South American tropics and subtropics will no longer be known to them."

2. The establishment of the National Research Council organized in 1916 as a measure of national preparedness, but continued after the war to encourage and promote research work in the physical and biological sciences, and to encourage the application and dissemination of scientific knowledge for the benefit of the nation.

3. The establishment by the California Institute of Technology of a department for biological investigations in their relationship to the physical sciences.

4. The publication of Biological Abstracts (beginning with the literature of 1926) under the auspices of the Union of American Biological Societies.

The individual workers mentioned are:

1. Alexis Carrel, who with (2) Ross G. Harrison, has done exceptional work in isolating and culturing not only single cells, but tissues as well, outside the body in which they normally grow. For Carrel's part in this work and in the suturing of blood vessels, he was made Nobel laureate in medicine in 1912.

3. C. M. Child, whose metabolic gradient theory has proved to be an incentive of importance in embryological speculation.

4. Jacques Loeb, born a German, but did his great 
work on artificial parthenogenesis in the States.

5. Robert Chambers, whose work on methods of microdissection has been of tremendous importance.

6. L. R. Cleveland, whose work on the partnership of wood-eating termites with infusorians living in the intestines and which are the intermediary that makes the ingested food digestible, has thrown new light on a hitherto unexplained phenomenon.

7. E. G. Conklin, whose work, as shown in his Heredity and Environment in the Development of Men, has had a great influence.

8. L. O. Howard, whose work on utilizing one pest to control another, is a modern classic in agriculture.

9. H. S. Jennings, whose investigations on the unicellular organisms is a pioneer piece of work which has contributed much toward an understanding of their movements and "psychic" reactions.

10. C. A. Kofoid, whose work on the reciprocal influence of the organism to its environment, is of fundamental importance.

11. Thomas Hunt Morgan, who ranks as the foremost worker on chromosomes and their constituents, genes, in the world.

12. G. H. Parker, whose work on tropisms is quite fundamental.

13. William E. Ritter, whose work on the Unity of the Organism, and his insistence on taking everything con- 
cerning the organism into consideration before coming to a valid conclusion, has influenced the philosophical biologists profoundly.

14. Major Walter Reed, who did exceptional work on the malarial mosquito.

15. William Richards, whose work on the revision of atomic weights and in physical chemistry brought him the Nobel Prize in chemistry in 1914.

16. Edmund B. Wilson, whose profound researches on the cell have given us a better understanding of that biological unit than probably the work of any other single individual.

17. Robert Yerkes, whose work, together with that of Mrs. Learned and Professor Kohler, on the intelligence of apes has made a profound impression.

In the field of speculative biology and biological philosophy, one may gauge the direction of the intellectual drift by the work of such men as:

Arthur Lovejoy (for a list of whose books and articles see Bibliography);

Edmund Noble, in his Purposive Evolution (1926).

William E. Ritter's The Unity of the Organism (2 vols., 1919).

H. C. Tracy's Toward the Open (1927).

T. H. Morgan, Critique of the Theory of Evolution (1916), The Physical Basis of Heredity (1919), and The Theory of the Gene (1926). 
E. G. Conklin's Heredity and Environment in the Development of Men (fifth edition, 1922).

\section{Latin America}

In these countries, as well as in the Scandinavian nations, Australia, and New Zealand, geographical influence is immediately apparent. Great areas, but slightly populated, with practically all pioneer work still to be done, such as one finds in Mexico, Central America, Brazil. Uruguay, Argentina, Chile, Bolivia, Paraguay, Peru, Columbia, Venezuela, and Ecuador, contain so much unknown, interesting, and valuable material, that the few scientific expeditions sent to those regions have been able to present but an infinitesimal glimpse of what may yet be discovered.

As the tropics and the semitropics have, for the most part, a luxuriant flora and fauna, with an endless variety of types and forms, undoubtedly many intermediate hosts of parasites at present unknown, are to be sought here, which, in turn, are likely to throw light on many unsolved present-day health problems.

Then, too, in a country where all men must do pioneer work of some nature, the first consideration is that of earning one's daily bread, and if any time remains, then, and only then, is such time applied toward seeking relief from immediate suffering; for, in all new countries, the medical man is the scientist. Specialization cannot come until later. 
Consequently, one notes in these regions an attempt to classify plants and animals thus far found and described. Great emphasis is placed on medicinal plants, and so the first specialization produces botanists, who, from medicinal plants, proceed to the study of agriculture. In the bulletins of the respective secretaries of agriculture, one may learn of what is done in these lands.

On the animal side, the problem of animal breeding and the veterinarian's work in trying to prevent epidemics among stock, the raising of which is the principal industry in some of these countries, looms high. This work, too, is under the direction of the various departments of agriculture and of animal husbandry.

The work on animals that affects the health of man is seen, for example, at the University of Cordoba, Argentina, where at some seasons of the year as many as 200 people daily apply for antirabies treatment. In the hinterland of Brazil, great numbers of venomous insects and reptiles are a constant source of injury to the populace. It is but natural, then, that the study of such problems is considered of preëminent importance. Only a few years ago, yellow fever was one of the dread scourges which sent shudders down the spinal cord of most people contemplating even a visit to the most beautiful city of all the Americas, Rio de Janeiro; while the stories of the endemic centers of typhoid and various tropical fevers kept many away.

Now Rio de Janeiro, as well as all other South American cities where the population is sufficiently dense to afford 
a health department, has overcome its yellow-fever epidemics, while the endemic centers of typhoid hold little terror. Snake bites and bites of poisonous spiders no longer mean death, and territory that was considered absolutely impossible for man's habitation has become a growing center of beauty and even of health.

Outstanding as the most spectacular scientific work in all Latin America is the snake farm of Dr. Vital Brazil, founded at Butantan, on the outskirts of Sao Paulo, in Brazil. All other snake farms of the world, every one of whose founders were students of Dr. Brazil, drew their inspiration from this remarkable mother institution.

Here one finds as many as 10,000 snakes at one time, sent in by inhabitants from all regions of the country. Payment for the snakes is made with little vials of antivenin which means so much in the interior of the country where snakes are many and physicians few.

In the museum on the farm are specimens of all those types and forms of reptiles and spiders, together with models of the lesions formed in man by their respective bites.

Rio de Janeiro has a great research institution, known as the Instituto Oswaldo Cruz, brought into existence by, and named after, the man who founded it - Oswaldo Cruz. To him, not only Rio de Janeiro, but all the tropics owe an everlasting debt of gratitude for changing yellow fever from the most-feared and from an ever-recurring epidemic to an almost unknown disease.

The present director of the Institute is Dr. Carlos Cha- 
gas, the discoverer of the parasite which is the cause of Chagas Disease, named after its discoverer. This tropical disease, characterized by enlarged glands, anæmia, and heretofore by death, is no longer invariably fatal.

Dr. Chagas is a man of tremendous energy, and after what Northerners have usually thought of the enervating influence of the tropics, one has but to meet their great men, to find that, as usual, most popular ideas are 100 per cent wrong.

Another man, part and parcel of the Institute, is Dr. Adolph Lutz, one of the very few South Americans ever asked to lecture in North America. He was brought to the United States by the American Philosophical Society to speak at their Bicentenary Celebration in 1927. The work of Dr. Lutz covers a period of a full half century, during which time he has made thousands of investigations on tropical parasitic forms of life.

Although the Institute is very large and employs several hundred men, it can furnish only enough sera for the army and navy. Private institutions of an industrial nature furnish the balance as needed by the medical profession in its private practice. Dr. Vital Brazil has founded one of these industrial institutes in Nictheroy, a suburb of Rio de Janeiro.

In the typhoid endemic regions, typhoid injections are given only to those who wish them. As these injections are not compulsory, and as there should be three injections with an intervening interval of several days, many who 
have had but one or two injections do not return, especially if they felt any unpleasant sensations after the first ones. The Brazilians consequently set to work on a new method of prevention which would appeal to the populace. They now are experimenting on a method by which the patient takes capsules containing the preventive substance internally. Thus far, the results seem to warrant the belief that this method will become widely used in the future.

Malaria, also, is ever present in the tropics and the semitropics. We are accustomed to think only of the Anopheles mosquito as carrying the disease, but it is interesting to know that the men working under the auspices of the Rockefeller Institute in Brazil and in the Argentine, have found several other species which carry the disease. They have thus added much to our supposed knowledge of what we had considered a more or less closed chapter in medicine.

Other diseases requiring immediate study on account of their prevalence are tropical splenomegaly, chronic ulcerative processes of the skin, leprosy, and syphilis. Hookworm is quite common as is also beriberi, dysentery, and smallpox.

Buenos Aires (Argentina) has a great Biological Institute which is a part of the National Health Department. Here, as in the Oswaldo Cruz Institute, the preventive as well as curative work of disease is undertaken. An idea of the quantity of work performed, and the rapid growth 
of such institutes can be gauged by the fact that but five years ago the institute needed only 18,000 units of one type of serum alone, and that in these five years the amount necessary to supply the demand has increased more than thirty times that sum.

At the present time, in the physicochemical laboratories of the institute, under the direction of Dr. Paul Wernicki, more than 25,000 units of insulin a year are prepared.

This Argentine Institute also prepares antivenin for snake and spider bites, but such work is rather subordinate to its other biological effort.

At all of the Argentinian medical schools, research of various kinds is carried on, the pathway down which the experimentation follows being determined by local conditions. Rosario is an industrial center, therefore one looks for investigative work peculiar to an industrial region. Cordoba is experimenting with new antirabies sera and finding success, for, as stated before, sometimes two hundred people who have been bitten by dogs, appear at this institution in a single day.

A little to the North of Cordoba is an inland salt sea, called Mar Chiquita, which their scientists claim has the greatest concentration of salt of any sea in the world. A single insect form is the only living organism ever found in this lake, whose water is made up of 29 per cent salt. An Argentine worker of the University of Buenos Aires, C. Jakob, is known the world over for his massive work on the nervous system, and Bernardo Houssay of the same 


\section{OUTSTANDING WORK AND WORKERS 103}

university, is often mentioned in American scientific papers.

In Chile, the most important work is considered to be that of their great biologist, Carlos E. Porter, who, for sixteen years, patiently worked out the complete life history of Chile's only venomous spider Latrodectos Formidabilis. This work was published in 1902. Dr. Porter's scientific contributions are analyzed and evaluated in Bibliografia Chilena Razonade de Ciencia Naturales. He is the founder and editor of the most comprehensive biological journal in South America - Revista Chilena de Historia Natural.

At the University of Chile, Juan Noe's work in physiology is considered of great value. $\mathrm{He}$ is an indomitable worker, while A. Lipschutz, of the new medical school in Concepcion, and late of the University of Elmland, Russia, is noted for his work on gland transplantation, and for his gathering into one volume all the known work in his field of effort.

In Cuba, the work of Dr. Carlos Finlay foreshadowed all modern experimentation in yellow fever. Dr. Finlay and Major Walter Reed are to the study of yellow fever what Ross and Manson are to the study of malaria.

In Central America, Costa Rica is considered by Science as the most advanced in the natural sciences, for that country has brought in various eminent workers of other lands to start their scientists down the newer scientific paths, and has not only followed their lead but has shown 
their appreciation by the many public honors rendered them.

In Mexico the work has again centered around the classification of food and medicinal plants, and agricultural effort. Professor A. L. Herrera has, however, developed what he calls a new biological science, named La Plasmogenia. He has been able to simulate living organisms by a number of oil droplets, and from his findings has attempted to work out a philosophy of life.

\section{EUROPE}

AUSTRIA

The Austrians, due to the impetus given through the rediscovery by Erich Tschermak, together with De Vries in Holland and Correns in Germany, of the work of their great countryman Johan Gregor Mendel, did a vast quantity of experimental work in general zoölogy and physiology. Side by side with this experimentation, much research is done in morphology and in systematic zoölogy. These latter efforts were developed especially by various scientific expeditions undertaken for that purpose, as well as by studies carried on with museum materials.

Further intensive studies were made on the ascertaining of new genera and species formation, and finally there was a search for new evidence which would substantiate or falsify the findings set forth in the older literature.

The most important names in biology are:

1. Johan Gregor Mendel, who deserves the title of the 
founder of all our modern ideas regarding genetics and heredity;

2. Erich Tschermak, whose rediscovery of Mendel's discoveries brought forth the great impetus for experimental work in Austria;

3. Eugen Steinach, whose work on gland transplantation and rejuvenescence has resulted in a world-wide impetus along these paths;

4. R. Barany, who won the Nobel Prize in medicine in 1914 for his work in the physiology and pathology of the semicircular canals of the ear;

5. Friederich Pregl, whose work with the ultramicroscope and his findings of new microanalytic methods brought him the Nobel Prize in chemistry in 1923.

6. Richard Zsigmondy, who became Nobel laureate in chemistry in 1925 for his extraordinary work on colloids.

7. Anton Handlirsch, renowned for his great work in entomological paleontology.

\section{BELGIUM}

The outstanding name in Belgium is that of Jules Bordet, authority on toxins, whose work on immunity and sera, and on whooping cough made him Nobel laureate in medicine in 1919.

\section{BRITISH IsLeS}

One of the interesting movements taking place in the British Isles is the establishment of the Empire Market- 
ing Board in London for the purpose of breeding insect parasites. These parasites will be shipped to all parts of the Empire, for agricultural purposes, wherever they may be needed to destroy noxious insects or plants.

Next, as a world influence, was the delivery of the Gifford Lectures in 1922, at the University of St. Andrews, by C. Lloyd Morgan. His theme of Emergent Evolution, published the following year, has brought forth what many biologists and philosophers consider a veritable via media that will solve the problems of Mechanism and Vitalism alike.

The foremost work and workers are:

1. Hardy and (2) Fischer, who showed that the cytoplasm had no visible structures, and that the older reticular, fibrillar, or other appearances described in detail in the later years of the nineteenth century, are artifacts due to fixing and staining. Such appearances can be mimicked in many other substances, such as the white of an egg, and the same cell will show different structures depending on the way it is treated. Yet the typical cell remains a microörganism with all its structures-nucleus with chromosomes and linin network, etc., mitochondria, chromidia, Golgi apparatus, centrosomes, etc.;

3. Hopkins and (4) Willcock, whose Amino Acids in Metabolism (1907) foreshadowed the finding of accessory food factors which could not be analyzed chemically, and which led to the discovery of vitamins;

5. Allen, whose work on the Artificial Culture of Marine 
Plankton Organisms showed that organisms require artificially, chemically pure solutions to be sensitized by natural waters before they can live and breed in them;

6. Wm. Bateson for his studies of variation;

7. Edward C. C. Baly for his discovery of artificial photosynthesis;

8. Elliott Smith for his work on the graduated improvement of the anterior region of the forebrain in a series of animals from the jumping shrew to man.

9. Sir F. Gowland Hopkins for his discovery of glutathione, an oxygen transporter.

10. D. Keilin for his discovery of the widely distributed uncolored cell pigment, cytochrome, which is of value as a controller of oxygen in the cell.

11. E. S. Russell for showing in his The Study of Living Things (1924) that there is an increasing importance of mental factors as a vera causa in organic evolution.

12. W. Trotter whose Instincts of the Herd (1919) throws light on social biology.

13. Sir Francis Galton and (14) Karl Pearson for their work on statistical biological studies.

And the following Nobel Prize winners whose outstanding work in chemistry and in medicine have a more or less wide biological application:

In Medicine:

Sir Ronald Ross for his work on malaria (1902) and A. V. Hill (1922) for his work on muscular reactions. 


\section{In Chemistry:}

Sir William Ramsay (1904) for his researches in rare atmospheric gases;

Sir Ernest Rutherford (1908) for his work on radioactive bodies;

Frederick Soddy (1921) for his work on radioactivity; and

Francis Wm. Aston (1922) for his work on spectrotherapy and on radioactivity.

\section{Czechoslovakia}

The traditional work of Czechoslovakia has always been in the fields of anatomy, physiology, cytology, and planktonology. To this must be added the work of later years on morphology, in heredity, on hormones, and on the nature of tropisms.

Prague, the oldest university of Central Europe and the only one in Czechoslovakia up to 1882, was, of course, under Austrian influence, and has become a German university. A real national university was opened in 1882, and only after the war (1919) was the second national university, that of Brno opened. The Czechoslovakian youth, therefore, had to gain their scientific training in secondary schools.

The great names in biology are:

1. J. E. Purkyne (Purkinje), one of the early workers whose researches led to the recognition of protoplasm, and who did a vast amount of work on the nervous system;

2. Beneden and (3) Boveri, known for their work on 
the centrosphere and for that on the composition of chromosomes; the latter especially for his work on the mechanics of cytology;

4. The late A. Mrazek, a renowed parasitologist, for his work primarily on Cestodes, Trematodes, and Copepods;

5. The late Ed. Babak, a renowned physiologist, for his work primarily on respiration and on internal secretions;

6. E. Studnicka for his work on histology and cytology;

7. K. Sulc, who founded the theory of intracellular and hereditary symbiosis, independently of Pierantoni;

8. The late A. Fric, because of his work as one of the founders of limnology;

9. Wenig, for his work on comparative vertebrate anatomy; and

10. V. Janda, for his work in general experimental zoölogy;

11. F. Vejdovsky, for his work on cell cleavage;

12. Nemec, for his work on starch grains in roots which showed these to be statocysts; and

13. Radl, for his history of biological theories.

\section{France}

The outstanding movements are:

1. The constant insistence upon the need of developing the Colonies, and some of the late meetings of the French Association seem to have been dominated with the idea that only such biological work is important as will assist in such development; and 
2. The organization of the new Institute of Physicochemical Biology for the purpose of studying the physicochemical mechanism of life.

The outstanding workers mentioned are:

1. The botanist Noel Bernard, for his work in the plant world, which is a sort of counterpart of Cleveland's work in the animal world. Bernard has shown that the germination of orchid seeds is closely dependent upon the presence of a partner fungus.

2. Yves Delage, whose work on artificial parthenogenesis deserves special mention;

3. Louis Pasteur, although belonging to an older generation, should always be named because his work and that of his disciples is so far-reaching and ever new;

4. Baltzer, for his work which showed that a mere displacement of young males of the green worm Bonellia viridis would cause them to develop into an intermediary sex form;

5. F. d'Herelle, for his discovery of the bacteriophage.

The remaining names are Nobel Prize men, whose distinctive work is the best criterion of what work Frenchmen emphasize.

6. Henri Moissan, in chemistry in 1906, for his work on the elements of fluorine and the introduction of the electric furnace into scientific technique;

7. Vikto Grignard, in chemistry in 1912, for his work in organic syntheses;

8. Paul Sabatier, in chemistry in 1912, for his remark- 
able work in industrial and agricultural chemistry;

9. Charles Richet, in medicine in 1913, for his work and researches on serum-therapy and for his discovery of anaphylaxis;

10. C. L. A. Laveran, in medicine in 1907, for his work on malarial fever and on the haematozoöns.

\section{Germany}

In Germany, the emphasis seems to have been laid on the biological problems of (1) the inheritance of acquired characteristics, (2) the origin of species, (3) the origin of mutations, (4) animal psychology, (5) embryology and regeneration, and lately $(6)$ the problem of vitalism which has led into psychic research.

Vitalism is regarded as a problem of philosophy, and is supposed to have been handed over to the philosophers by the biologists, but from the interest displayed by the biologists themselves, it is safe to say that the handing over has not been complete.

It is interesting to note that only the Holland and the Mexican correspondents were outspoken mechanists, while the Germans, the Americans, the Canadians, and some English workers looked to Emergent Evolution as a theory from which great things may be expected. Not one of these latter was willing to consider himself an out-and-out mechanist; neither did the majority wish to be classified as out-and-out vitalists.

One of the German correspondents has put it in these 
words: Vitalism is considered very important because "it is the only biological influence on practical life - that is, the theory of vitalism - for it not only liberates the mind from materialism in every respect, but also has a decided effect on morality - on the conduct of man."

The great names mentioned are:

1. Thienemann who, with his school, did a vast amount of research, as did Kofoid in the United States, on the reciprocal influence of the organism to its environment;

2. William Roux, whose interesting separation of the growing cells in the newly developing embryo inaugurated a discussion which formed the impetus for much of our work in modern experimental embryology;

3. Hans Driesch, whose really remarkable work in embryology and regeneration brought about the parting of the ways for the modern schools of mechanism and vitalism;

4. F. Alverdes, whose Tier Soziologie is a sequel to Trotter's Instincts of the Herd in England;

5. D. Keilin, now in England, whose discovery of cytochrome is mentioned under workers in the British Isles;

6. K. von Frisch, whose explanation of the way honeybees let others in the hive know of their discovery of nectar is of exceptional interest;

7. R. Goldschmidt, whose metabolic theory of sex determination is of outstanding prominence just now.

And here are other names mentioned: (8) Bern, (9) 
Correns, codiscoverer with De Vries and Tschermak of the Mendelian papers in 1900; (10) Curt Herbst; (11) Hans Spemann; (12) Rangold; (13) von Ruddenbrock; and (14) Jakob von Uexkull.

Nobel Prize winners were:

In Chemistry:

E. Fischer (1902) for his work on the synthesis of sugars and proteins;

Adolph von Bäyer (1905) for his work on the synthesis of indigo;

Eduard Buchner (1907) for his work on the chemistry of fermentation;

Wilhelm Ostwald (1909) for his work on catalysis of chemical reactions engendered by the dissolution of electric currents;

Otto Wallach (1910) for his work and research in industrial chemistry of the terpenes and oxalines;

Richard Willstätter (1915) for his work and researches on chlorophyll and for his theory of color;

F. Haber (1918) for his work on the processes involved in the synthesis of ammonia;

Walther Nernst (1920) for his work on electromotive chemistry and thermodynamics.

In Medicine:

E. A. von Behring (1901) for his work in serotherapy and prophylaxis;

Robert Koch (1905) for his work on tuberculosis; 
Paul Ehrlich (1908) for his researches on immunity;

Albrecht Kossel (1910) for his work on albuminoid substances and the derivatives of nucleic acid;

O. Meyerhaff (1922) for his work on the transformation of energy in muscles.

\section{Holland}

The work emphasized by the correspondents from Holland was entirely confined to a mention of De Vries' mutation theory and the results of various scientific expeditions described in:

1. Monographs of the Siboga Expedition; and

2. Nova Guinea; Résultats de l'expéd. scientif. Néerland, (à la Nouv. Guinée. 1917).

The important workers mentioned were:

1. De Vries for his book Die Mutationtheorie;

2. Weber for his Die Saugethiere; and the two Nobel Prize men;

3. L. H. van't Hoff, in chemistry in 1901, for his studies on molecular structures, on solutions, and on salt deposits; and

4. Willem Einthoven, in medicine in 1924, for his work with the electrocardiograph in measuring heart-action currents.

\section{ITALY}

Here one finds great emphasis on morphology and some on endocrinology. Nearly all biological efforts have for their goal some practical application of immediate na- 
tional or local need. The volume summing up Italian biological history is entitled:

I Progressi della Biologia e delle sue Applicazioni practiche consequiti in Italia nell' ultimo cinquantennio. Rome (1911).

The great names in Italian biology are:

1. Artrom, for his work on the relationship of the nucleus and the cytoplasm, and for his work on chromosomes and genetics;

2. Bruschettini, for his work on diphtheria;

3. Celli, (4) Grassi, and (5) Marchiafava for their work on the malarial parasite;

6. Cotronei, for his work on the experimental morphology of the development of the eye;

7. Enriques, for his work on the reproduction of protozoans;

8. Ghigi, for his work in genetics;

9. Giacomini, for his work concerning the action of the thyroid gland on the metamorphosis of Amphibia;

10. Giardina, for his work on the dorsal cord;

11. C. Golgi, for his work on the anatomy of the nervous system and his studies on the malarial parasite which brought him the Nobel Prize in 1906;

12. Levi, for his work on tissue culture;

13. Pentimalli and (14) Fichera, for their work on cancer;

15. Raffaele, Giacomini, Giardina, and Cotronei for their work on the mechanism of development;

16. Ruzzini, for his work in embryology and for his 
great book, recently published, entitled Fisiogenia;

17. Silvestri and Berlese on agricultural entomology.

\section{Poland}

Although she did her work in France, Madame Marie S. Curie (nee Marie Sklodowska) is Polish-born, and was educated in Warsaw. In 1911 she received the Nobel Prize in chemistry for her discovery of radium and polonium. She has two unique distinctions, (1) of being the only woman to be Nobel laureate in any science, and (2) of being the only person of either sex who has received the Nobel Prize in two separate fields of learning - chemistry and physics.

\section{RUSSIA}

It has been as difficult to get any reliable information about Russian science as it is to get it about Russian politics, but several names are well known throughout the scientific world and should be mentioned here.

They are :

1. S. Korschinsky, whose mutation theory is best known to us through the German items appearing at various times in European papers. His "Heterogenesis and Evolution" appeared in Natur Wochenschrift, Vol. XIV, 1899, and again "Heterogenesis u. Evolution," in Flora, oder Allg. Bot. Zeit. Erganzungsbd. 89, 1901.

2. Elie Metchnikoff, whose work on immunity in infectious diseases and the prolongation of life, made him Nobel laureate in medicine for 1908. 
3. Ivan Petrovich Pavlov, whose work as discussed in his The Work of the Digestive Glands (English Translation, 1902) and his researches on cerebral activity and the theory of reflexes brought him the Nobel Prize in medicine for 1904. For a good account of his work see M. Dontchef-Dezeuse L'Image et Reflexes Conditionals dans les Travaux de Pavlov (1914).

4. Serge Voronoff, whose work on gland grafting has made him, together with Eugen Steinach, one of the outstanding leaders in this field of research.

5. Besredka and (6) Plotnikow should be mentioned for their work in what may be termed biological medicine.

ScAndinavia

NORWAY

The Norwegians consider the founding of the series Neue Studien über die Reifung der Geschlechtszellen as an outstanding movement. This series is probably the most important of all their biological publications.

The great names of Norway are:

1. K. E. Schreiner and his wife (2) Mrs. A. Schreiner, for their work on the maturation of germ cells, a work which definitely settled the question as to the conjugation and reduction of chromosomes, thus rendering a safe basis for the modern cytological study of the problems of heredity.

3. H. H. Gran, whose Das Plankton des Norwegischen Nordmeeres is without question the very foundation of modern marine planktonology. 
4. Johan Hjort and Sir John Murray, whose Depths of the Ocean (London, 1912) is significant because it gives a very valuable account of the important Michael Sars Expedition of 1910. A new turning point to marine investigations was given by this work, primarily because it introduced a new technique, but mostly by its elaborate discussions of marine problems and its furnishing a new point of view for marine questions. Hjort's Fluctuations in the Great Fisheries of Northern Europe is, however, probably the more important, because this work has been the cause of a collaboration and a coördination between biological theory and practice unthinkable a few years ago. Hjort makes clear just what effect these fluctuations have throughout all living organisms. He shows how, by a biological understanding theoretically worked out, we obtain an understanding of nature that, in turn, is the real cause of practical application in all those industries which have anything to do with the handling, raising, or selling of either the living things themselves or any products derived therefrom.

Among the older workers are: (5) Johan Ernst Gunnerus; (6) Michael Sars; (7) Georg Ossian Sars.

\section{SWEDEN}

To Sweden we owe the existence of one of the foremost international institutions of all the world - that of the Nobel Institute - which gives to deserving scientific men not only a substantial prize for exceptional work of an 
international character, but what is of greater worth, makes such men and their work known to the entire world. It is, in a measure, comparable with only one other organization that touches the biological world on many sides the Rockefeller Institute of the United States.

Among great Swedish biological workers one finds mention of :

1. Einer Naumann, for his work on the reciprocal influence of the organism to the environment.

2. Alvar Gullstrand, who received the Nobel Prize in medicine in 1911, for his work on dioptics;

3. S. A. Arrhenius, and (4) Theodore Svedberg, Nobel laureates in chemistry, the former in 1903 for his ionization hypothesis, and the latter in 1926 for his work in physical chemistry.

\section{DENMARK}

The Danes are:

1. N. R. Finsen, whose work in applying violet rays to therapeutics won him the Nobel Prize in medicine in 1903 , and

2. A. Krogh, whose work on capillaries made him Nobel laureate in medicine in 1920.

\section{FinLAND}

The Finns are represented by:

O. Aschan, who received the Nobel Prize in chemistry for his work on the chemistry of rubber in 1917. 


\section{SPAIN}

When one thinks of Spain from a scientific point of view, one name that seems to spring forth instantly is that of S. Ramon y Cajal, one of the world's great leaders of histological research, especially as applied to the anatomy of the nervous system. In fact, the Nobel Prize in medicine came to him and to Golgi in 1906 for this work. In a recent letter to the author, Professor Ramon y Cajal bemoans the fact that while the scientific world reads English, French, and German, the language of the Hispanic peninsula remains an unknown page to scientists.

And one has but to go over his interesting Recuerdos de mi Vida, a big book of over 500 pages, to realize that his reproach is not unmerited. The Brazilians and the Portuguese have the same reproach, for, while workers in these countries subscribe to and read our journals, we know nothing of their work and publications unless some national figure of other lands discovers, usually by accident, an outstanding worker in fields whose language is not among the "big three." It was so even with Ramon y Cajal. Had it not been for the German, W. Krause, who was so impressed by the young Spaniard's work that he called his fellow scientists' attention to it, even this greatest of living anatomists might have remained unknown to us.

Ramon y Cajal and his students have done so much work that the reader must be referred to the book previ- 
ously mentioned, now in its third edition, for the hundreds of important findings there recorded.

\section{SWITZERLAND}

Switzerland, bordered by Germany, Austria, France, and Italy, finds its various regions lying closest to each of these lands influenced by them. Thus, Switzerland has really no distinctive contribution to offer. It partakes of all Europe, so to speak. Nevertheless, this little country has produced two Nobel laureates:

Theodore Kocher in medicine for 1909, for his researches in the physiology, pathology, and surgery of the thyroid body, and Alfred Werner in chemistry for 1913, for his work on valence and on chemical constitution.

\section{Asia}

INDIA

As with Spain, so with India, there is one outstanding biological worker known to all the Western World. He is Sir Jagadis Chunder Bose, whose work on the so-called nervous system of plants has laid a foundation for enough experimentation to keep botanists busy for an entire generation. All of his experimental results are not only interesting, but they show what really can be done by patiently working out fine and finer mechanisms with which to experiment.

His outstanding works are mentioned in the bibliography. 


\section{JAPAN}

Here there are two names known to the Western World:

1. Hideyo Noguchi, whose work has been done mostly in the United States. He is known for his researches on snake venoms; for a new method of obtaining pure vaccine for smallpox; for working out a pure cultivation of syphilitic organisms; for his microscopic work in infantile paralysis; for his proving that treponema pallidum is present in the brain in general paresis as well as in the spinal cord in locomotor ataxia, and finally, for the introduction of a skin test for syphilis.

For an account of his work see S. Paget's "Noguchi's Researches in Infective Diseases," Science, Nov. 21, 1913.

2. Shibasaburo Kitasato, one of Japan's most eminent bacteriologists, discovered the cause of the bubonic plague in 1894 and the dysentery bacillus in 1898 .

\section{Australia and New Zealand}

From this region come two of the best-known biologists in the English-speaking world, whose great A Text Book of Zoölogy has passed through three editions and is still a standard work of reference. They are William A. Haswell, of the University of Sydney in Australia, and T. Jeffery Parker, of the University of Otago, New Zealand.

In this far-off region where there is little opportunity of intellectual intercourse with the center of scientific work, each worker is kept busy with teaching and ad- 
ministrative duties. Nevertheless, great things have come from these overworked men.

The work has been mostly along morphological and systematic lines.

Their best-known biologists, in addition to those just mentioned are: Leonard Cockayne, whose work has shown that many New Zealand plants are not species but hybrids. This type of work was inspired by the Dutch botanist Lotsy's visit to New Zealand a few years back.

Then there is Chilton's work on Crustacea, Benham's on Annelida, Tillyard and Nelson on insects in general, Philpot on Lepidoptera, and finally W. E. Agar on Cytology. 


\section{BIBLIOGRAPHY}

Agar, W. E., Cytology, 1920, The Macmillan Co., New York City.

ALdRICH, J. M., "The Limitations of Taxonomy," April 22, 1927, Science, New York City.

Armstrong, E. F., Chemistry in the Twentieth Century, 2nd Edition, 1924, London, England.

Barry, Frederick, Scientific Habit of Thought, 1927, Columbia University Press, New York City.

Bateson, W., Mendel's Principles of Heredity, 1913.

Problems of Genetics, 1913.

Beach, Frederick E., "On the Study of Physics," Vol. 65, p. 61, 1904, Popular Science Monthly, New York City.

Bergson, Henri Louis, Creative Evolution, 1911, Henry Holt \& Co., New York City.

BoGGILD, O. B., Meeresgrundproben der Siboga Expedition, 1916.

BоHN, G., Le Mouvement Biologique en Europe, 1921.

BorradaIle, L. A., The Animal and Its Environment, 1923, Oxford University Press, New York City.

Bose, SIR JAgadis ChUnder, Response in the Living and the Nonliving, 1902, Longmans, Green \& Co., New York City.

Researches on Irritability of Plants, 1913, Longmans, Green \& Co., New York City.

Physiology of Photosynthesis, 1924, Longmans, Green \& Co., New York City.

Nervous Mechanism of Plants, 1926, Longmans, Green \& Co., New York City.

Plant Autographs and Their Revelations, 1927, The Macmillan Co., New York City.

Boule, M., Les Hommes Fossiles, 1921.

Bower, F. O., Botany of the Living Plant, 2nd Edition, 1923, The Macmillan Co., New York City.

BoverI, TH., "Über den Einfluss der Samenzelle und die Larvencharacter der Echiniden," Arch. f. Entw'mch., Bd. 16, pp. 340-363. 
Bridgman, P. W., The Logic of Modern Physics, 1927, The Macmillan Co., New York City.

Brooks, W. K., Foundations of Zoölogy, Columbia University Biological Series, Vol. 5, (Rev. Ed.) 1915, The Macmillan Co., New York City.

BRUECKE, E., Die Elementarorganismen. Sitzungsbericht der K. K. Akad. zu Wien, Bd. 44, pp. 381-406, 1861.

Burkitr, M. C., Our Early Ancestors, 1927, The Macmillan Co., New York City.

Burns, David, An Introduction to Biophysics, 1921, The Macmillan Co., New York City.

Burrows, M. T., "The Culture of Tissues of the Chick Embryo Outside of the Body," Vol. 60, 1910, Journal of the American Medical Association, Chicago, Ill.

"The Growth of Tissues of the Chick Embryo Outside the Animal Body, with Special Reference to the Nervous System," Vol. 10, pp. 63-83, 1911, Journal of Experimental Zoölogy, Philadelphia, Pa.

Cajal, S. Ramon y., Recuerdos de mi Vida, 3rd Edition, 1923, Madrid, Spain.

Calvert, Amelia C. Smith, A Year of Costa Rican Natural History, 1917, The Macmillan Co., New York City.

CaMac, C. N. B., Epoch-Making Contributions to Medicine, Surgery, and the Allied Sciences, 1909.

Canson, W. B., "The Emergency Function of the Adrenal Medulla in Pain and the Major Emotions," Vol. 33, pp. 356-372, 1914, American Journal of Physiology, Baltimore, Md.

"The Interrelations of the Emotions as Suggested by Recent Physiological Researches," Vol. 25, p. 262, 1914, American Journal of Psychology, Ithaca, N. Y.

Bodily Changes in Pain, Hunger, Fear, and Rage, 1920, D. Appleton \& Co., New York City.

Carlson, A. J. and Woelfer, A., "On the Internal Secretion of the Thyroid Gland," Vol. 26, pp. 32-67, 1910, American Journal of Physiology, Baltimore, Md.

Carret, A. and Burrows, M. T., "Cultivation in Vitro of the Thyroid Gland," Vol. 13, pp. 416-421, 1911, Journal of Experimental Medicine, New York City. 
"On the Physiochemical Regulation of the Growth of Tissue," Vol. 13, pp. 562-570, 1911, Journal of Experimental Medicine, New York City.

"Cultur de Substance renal endehors de L'Organisme," t. 69, pp. 298-99, 1912, C. R. Soc. Biol., Paris.

Castle, W. E., Heredity in Relation to Evolution and Animal Breeding, 1913.

Genetics and Eugenics, (Full Bibliography.) 1924, Harvard University Press, Cambridge, Mass.

Chambers, R., Microdissection Studies on the Physical Properties of Protoplasm, 1915, Lancet-Clinic, Cincinnati, Ohio.

"Microdissection Studies I, II, and III," 1917-1921, Journal of Experimental Zoölogy, Philadelphia, Pa.; American Journal of Physiology, Baltimore, Md., and Biological Bulletin, XLI.

"The Microvivisection Method," 1917, Biological Bulletin. XXXIV. "A Microinjection Study on the Permeability of the Starfish Egg," 1922, Journal of General Physiology, V, New York City.

"New Apparatus and Methods for the Dissection and Injection of Living Cells," 1922, Anatomical Record, XXIV, Philadelphia, Pa. "The Physical Structure of Protoplasm as Determined by Microdissection and Injection," General Cytology, 1924, University of Chicago Press, Chicago, Ill.

CHud, C. M., Individuality in Organisms, 1915, University of Chicago Press, Chicago, Ill.

Senescence and Rejuvenescence, 1915, University of Chicago Press, Chicago, Ill.

The Origin and Development of the Nervous System, 1921, University of Chicago Press, Chicago, Ill.

Cockerell, T. D. A., "Duty of Biology," April 9, 1926, Science, New York City.

Conkliv, E. G., "The Organization and Cell Lineage of the Ascidian Egg," 2nd Series, Vol. 13, pp. 5-119, 1905, Journal of the Academy of Natural Science, Philadelphia, Pa.

"The Mechanism of Heredity," Vol. 27, pp. 89-99, 1908, Science, New York City.

"Cell Size and Nuclear Size," Vol. 12, pp. 1-98, 1912, Journal of 
Experimental Zoölogy, Philadelphia, Pa.

Direction of Human Evolution, 1922, Charles Scribner's Sons, New York City.

Heredity and Environment in the Development of Man, 5th Edition, Princeton University Press, Princeton, N. J.

Cortezo, C. M., Cajal, su personalidad, su obra, su escuela, 1922, Madrid, Spain.

Cowdry, E. V., "The Development of the Cytoplasmic Constituents of the Nerve Cells of the Chick," Vol. 15, pp. 389-428, 1914, American Journal Anat.

"The General Functional Significance of the Mitochondria," Vol. 19, pp. 389-428, 1916, American Journal Anat.

Cowdry, E. V. AND others, General Cytology, 1924, University of Chicago Press, Chicago, Ill.

CrILE, G. W., Man - An Adaptive Mechanism, 1916, New York City. Bipolar Theory of Living Processes, 1926, The Macmillan Co., New York City.

Cumston, Charles G., An Introduction to the History of Medicine, 1926, Alfred A. Knopf, New York City.

Cushing, H., The Pituitary Body and Its Disorders, 1912, Philadelphia, Pa.

Dana, C. L., The Peaks of Medical History, 1926, Paul B. Hoeber, New York City.

Darbishire, A. D., An Introduction to Biology, 1917, Funk \& Wagnalls Co., New York City.

Darwin, Lenard, Organic Evolution; Outstanding Dificulties and Possible Explanations, The Macmillan Co., New York City.

Davies, A. M., An Introduction to Palaeontology, 1920, D. Van Nostrand Co., New York City.

DAWydofF, C., "Restitution von Kopfstücken, die vor der Mundöffnung abgeschnitten waren, bei den Nemertinen (Lineus lacteus)," Bd. 36, pp, 1-6, 1910, Zoöl. Anz.

DE BEeR, G. R., Growth, 1924, Longmans, Green \& Co., New York City.

Dendy, A., Outlines of Evolutionary Biology, (Revised.) 1923, D. Appleton \& Co., New York City. 
Deniker, J., The Races of Man, 1906, New York City.

Dewey, JoHn AND others, Creative Intelligence, 1917, Henry Holt \& Co., New York City.

Ditmars, Raymond L., Reptiles of the World, 1927, The Macmillan Co., New York City.

Dobell, C. C., "The Principles of Protistology," Bd. 23, pp. 269-310, 1911, Arch. f. Prot'k.

Dontchef-Dedeuze, L'Image et Reflexes Conditionnels dans les travaux de Pavlov.

Doncaster, L., The Determination of Sex, 1914, The Macmillan Co., New York City.

An Introduction to the Study of Cytology, 1920, The Macmillan Co., New York City.

DrIEsCH, H., "Der Wert der beiden ersten Furchungszellen in der Echinodermenentwicklung," Vol. 53, 1891, Zoöl. Zeitschr. f. Wiss. "Entwicklungsmechanische Studien IV," Vol. 55, 1893, Zoöl. Zeitschr. f. Wiss.

Analytische Theorie der organischen Entwicklung, 1894, Leipzig.

Science and Philosophy of the Organism, 2 Vols., 1907, The Macmillan Co., New York City.

DrIESCH, H. AND MORGan, T. H., "Zur Analysis der ersten Entwicklungsstadien des Ctenophoreneies. I. Von der Entwicklung einzelner Ctenophorenblastomeren," Bd. 2, pp. 204-215, 1895, Arch. f. Entw'mch.

Duckworth, W. L. H., Morphology and Anthropology, 1915, The Macmillan Co., New York City.

Dudley, Owen Francis, Will Men be Like Gods?, 1929, Longmans, Green \& Co.

EAst, Edward M. AND Jones, D. F., Inbreeding and Outbreeding, 1919, J. B. Lippincott Co., Philadelphia, $\mathrm{Pa}$.

Ebernvg, A. H., "The Permanent Life of Connective Tissue Outside of the Organism," Vol. 17, pp. 273-285, 1913, Journal of Experimental Medicine, New York City.

EldRIDGe, Seba, "The Organization of Life," 1925, Review by W. E. Ritter in Science, New York City, Feb. 5, 1926. 
Evans, C. Lovatr, Recent Advances in Physiology, 2nd Edition, 1926, P. Blakiston's Son \& Co., Philadelphia, Pa.

Falta, W., The Ductless Glandular Diseases, (Meyer's trans.) 1915, New York City.

Fischer, Albert, Gewebezüchtung. Handbuch der Biologie der Gewebezellen in Vitro, 1927, Munich.

Flattley, F. W. And Walton, C. L., Biology of the Seashore, 1922, The Macmillan Co., New York City.

France, RaOul H., Grundriss der vergleichenden Biologie, 1924, Leipzig.

Bios, Die Gesetze der Welt, 1926, Munich.

Foulller, Alfred, Esquisse Psychologique des Peuples Europeens, 1903, Paris.

Galton, SIR Frances, Natural Inheritance, 1889.

Garrison, F. H., "Ductless Glands, Internal Secretions, and Hormonic Equilibrium," Vol. 85, pp. 531-540, Vol. 86, pp. 92-99, 142-152, 1914-1915, Popular Science Monthly, New York City.

Gates, R. R., "Heredity and Mutation as Cell Phenomena," Vol. 2, pp. 519-528, 1915, American Journal of Botany.

Gibbs, J. Willard, "Elementary Principles of Statistical Mechanics," 1902, Yale Bi-Cen. Pub.

Giddings, Franklin H., Vol. 34, No. 1, p. 151, 1919, Political Science Quarterly, New York City.

Giesen, John and Malumphy, Thomas L., Backgrounds of Biology, 1929, The Bruce Publishing Co., Milwaukee, Wis.

Goldenweiser, AleXander A., Early Civilization: An Introduction to Anthropology, 1922, Alfred A. Knopf, New York City.

Goldschmid, R. B., The Mechanism and Physiology of Sex Determination, 1923, George H. Doran Co., Garden City, New York.

"The Quantitative Theory of Sex," June 17, 1927, Science, New York City.

Goodrich, E. S., Living Organisms, 1925, Oxford University Press, New York City.

Gran, H. H., "The Plankton Production in the North-European Waters in Spring," 1912, Bulletin Planktonique. 
Grassi, Battista, I Progressi della Biologia e delle sue applicazioni pratiche. Consequiti in Italia nell'ultimo cinquantennio, 1911, Rome. Gregory, WM. K., "Two Views of the Origin of Man," June 24, 1927, Science, New York City.

Gunther, Hans F. K., The Racial Elements of European History, (English trans.) 1927, New York City.

Haddon, A., History of Anthropology, 1910, London.

Haldane, J. S., Mechanism, Life and Personality, 2nd Edition, 1923, E. P. Dutton \& Co., New York City.

Organism and Environment, 1917, Yale University Press, New Haven, Conn.

The New Physiology, 1919, J. B. Lippincott Co., Philadelphia, Pa. Handlirsch, Avron, Insecta palaezoica, (Rev. Ed.) 1919, Catalogus Fossilium, Vienna.

Beiträge z. Kenntniss d. palaeozischen Blattarien, 1920, Vienna.

Hankins, Frank H., The Racial Basis of Civilization; A Critique of the Nordic Doctrine, 1926, Alfred A. Knopf, New York City.

HaRdeNs, A., "Enzymes and Inhabitants," Dec. 7, 1912, p. 363, Science, American Supplement.

HenINCKe, Fr., The Occurrence and Distribution of the Eggs, Larvae, and Various Age Groups of the Food Fishes in the North Sea, Conseil internat. pour. l'explor. de la mer, Rapp. et proc. verb., 13 , Appendix E, pp. 1-39, 1902-4.

Heinecke, Fr. and Ehrenbaum, E., "Eier und Larven von Fischen der deutschen Bucht. II. Die Bestimmung der schwimmenden Fischeier und die Methodik der Eimessungen." Wissenchaftliche Meeresuntersuchungen neue Folge, Bd. 3, 1898.

Henderson, L. J., The Fitness of the Environment, 1913, The Macmillan Co., New York City.

Herbst, C., "Vererbungsstudien VI. Die cytologischen Grundlagen der Verschiebung der Vererbungsrichtung nach der mütterlichen Seite" Bd. 27, pp. 266-308, 1909, Arch. f. Entw'mch.

Herrera, Alfonso L., La Biologia en Mexico durante un Siglo, 1921, Mexico City.

La Plasmogenia, 1921, Barcelona. 
Herrick, C. Judson, Fatalism or Freedom: A Biologist's Answer, 1926, W. W. Norton \& Co., Inc., New York City.

Hertoghe, E., "Some Remarks on Thyroid Deficiency," Vol. 20, p. 194, 1914, American Medicine.

Hertwig, R., "Die Protozoen und die Zelltheorie," Bd. I, pp. 1-40, 1902, Arch. f. Prot'k.

"Über neue Probleme der Zellenlehre," 1908, Arch. f. Zellforschung, I.

Über den derzeitigen Stand des Sexualitätsproblems nebst eigenen Untersuchungen," Bd. 32, pp. 65-111, 1912, Biol. Centralbl.

Hrll, A. V., Living Machinery, 1927, Harcourt, Brace \& Co., New York City.

HJort, Johan, The Unity of Science, 1922, New York City.

"Fluctuations in the Great Fisheries of Northern Europe," 1914, in Vol. XX, Rapports et Proces-Verbaux, Conseil Permanent International pour l'Exploration de la Mer, Copenhagen.

Hjort, JoHan and Murray, Sir John, Depths of the Ocean, 1912, The Macmillan Co., New York City.

Hogben, L. T. AND Winton, F. R., Introduction to Recent Advances in Comparative Physiology, 1925, The Macmillan Co., New York City.

HoLmes, S. J., "The Life of Isolated Muscle Cells," Vol. 40, pp. 271272, 1914, Science, New York City.

Hoover, Herbert, "The Nation and Science," January 14, 1927, Science, New York City.

Hoprins, F. G., "The Dynamic Side of Biochemistry," Vol. 92, pp. 213-226, 1913, Nature Magazine, Washington, D. C.

HuxLeY, J. S., Bird Watching and Biological Science, Vol. XXXIII, p. 142, 1916, Auk, Cherrydale, Va.

Essays of a Biologist, 1923, Alfred A. Knopf, New York City.

The Differentiator, June, 1924, Discovery.

Jennings, J. S., Behavior of the Lower Organisms, 1906, Vol. 10, Columbia University Biological Series, Columbia University Press, New York City.

"Observed Changes in Hereditary Characters in Relation to Evolu- 
tion," Vol. 7, pp. 281-301, 1917, Journal of the Washington Academy of Sciences, Washington, D. C.

"Biology and Experimentation," July 30, 1926, Science, New York City.

Life and Death, Heredity and Evolution in Unicellular Organisms, 1920, The Gorham Press, Boston, Mass.

"Diverse Doctrines of Evolution, Their Relation to the Practice of Science and Life," January 14, 1927, Science, New York City.

Jenkinson, J. W., Experimental Embryology, 1909, Oxford University Press, New York City.

Johannsen, W., Traek af de biologiske Videnskabers Udvikling $i$ det nittende Aarhundrede, 1922, Copenhagen.

Johnstone, JAmes, The Philosophy of Biology, 1914, The Macmillan Co., New York City.

The Mechanism of Life in Relation to Modern Physical Theory, 1921, Longmans, Green \& Co., New York City.

Jolly, J., A propos de communications de $M$. M. Alexis Carrel et Montrose J. Burrows sur la "culture des tissues." t. 69 pp. 470-473, C. R. Soc. Biol., Paris.

Keeble, Sir Frederick William, Plant-Animals; A Study in Symbiosis. The Cambridge Manuals of Science and Literature. 1910, The Macmillan Co., New York City.

Kellogg, Veknon L., Darwinism To-day, 1907, New York City.

"The Present Status of University Men in Russia," Nov. 25, 1921, Science, New York City.

"The Biologist Speaks of Life," Vol. 127, pp. 583-593, 1921, Atlantic Monthly, Boston, Mass.

Human Life As the Biologist Sees It, 1922.

"World Trouble and Realism," Vol. 216, pp. 765-772, 1922, North American Review, New York City.

Mind and Heredity, 1923, Princeton University Press, Princeton, N. J. "Recent Biology and Its Significance," Vol. 217, pp. 746-759, 1923, North American Review', New York City.

International Biology, 1925, National Research Council, Washington, D. C.

"Some Things Science Doesn't Know," April, 1926, The World Today. 
KePNer, W. A., Animals Looking Into the Future, 1925, The Macmillan Co., New York City.

KERR, J. G., "Biology and the Training of the Citizens," Vol. 64, pp. 283-290, 1926, Science, New York City.

Kofom, C. A., "On the Relative Numbers of Rhizopods and Flagellates in the Fauna of Soils," Vol. 42, pp. 939-940, 1915, Science, New York City.

Kolle and Wassermann, Handbuch der pathogenen Mikroorganismen, 1911, Jena.

KRUMBHAaR, E. B., "The Lure of Medical History," July 1, 1927, Science, New York City.

KyLE, H. M., The Biology of Fishes, 1926, The Macmillan Co., New York City.

Korschinsky, S., "Heterogenesis and Evolution," Vol. XIV, 1899, Natur Wochenschrift.

"Heterogenesis und Evolution," Flora, oder Allg. Bot. Zeit, Ergänzungsbd. 89, 1901.

Lamarck, J., Zoölogical Philosophy, (Elliot trans.) 1914, The Macmillan Co., New York City.

Lee, Frederic S., Scientific Features of Modern Medicine, 1911, Columbia University Press, New York City.

Lewis, M. R. AND LEwIS, W. H., "Mitochondria (and Other Cytoplasmic Structures) in Tissue Culture," Vol. 17, p. 339, 1915, American Journal of Anatomy, Philadelphia, Pa.

Lenz, Adolf, Grundriss der Kriminal-Biologie, 1927, Vienna.

Lewis, M. R. AND Robertson, W. R. B., "The Mitochondria and Other Structures Observed by the Tissue Culture Method in the Male Germ Cells of Chorthippus Curtipennis Scudd," Vol. 30, pp. 99-124, 1916, Biological Bulletin of the Marine Biological Laboratory, Woods Hole, Mass.

LIESEGANG, Beiträge z.e. Kolloidchemie des Lebens, 1923.

LmLIE, F. R., "Observations and Experiments Concerning the Elementary Phenomena of Embryonic Development in Chaetopterus," Vol. 3, pp. 153-268, 1906, Journal of Experimental Zoölogy, Philadelphia, $\mathrm{Pa}$.

Problems of Fertilization, 1919, University of Chicago Press, Chicago, Ill. 
Lillex, Ralph S., "Physical Indeterminism and Vital Action," Aug. 12, 1927, Science, New York City.

Lipschutz, AleXANder, Internal Secretions of the Sex Glands, 1924, Williams \& Wilkins Co., Baltimore, Md.

Little, Arthur D., "The Fifth Estate," Oct. 3, 1924, Science, New York City.

Locy, William A., Biology and Its Makers, 1908, Henry Holt \& Co., New York City.

The Main Currents of Zoölogy, 1918, Henry Holt \& Co., New York City.

The Growth of Biology, 1925, Henry Holt \& Co., New York City. LoeB, J., Comparative Physiology of the Brain and Comparative Psychology, 1902, New York City.

The Dynamics of Living Matter, Vol. 8, 1906, Columbia University Biological Series, Columbia University Press, New York City.

"Concerning the Theory of Tropisms," Vol. 4, pp. 151-190, 1907, Journal of Experimental Zoölogy, Philadelphia, $\mathrm{Pa}$.

The Mechanistic Conception of Life, 1912, Chicago.

The Organism as a Whole; From a Physicochemical Viewpoint, 1916, G. P. Putnam's Sons, New York City.

Artificial Parthenogenesis and Fertilization, (English trans.) 1913, University of Chicago Press, Chicago, Ill.

Forced Movements, Tropisms, and Animal Conduct, 1918, J. B. Lippincott Co., Philadelphia, Pa.

Lotka, Alfred J., Elements of Physical Biology, 1924, Williams \& Wilkins Co., Baltimore, Md.

Lovejoy, Arthur O., "Eighteenth Century Evolutionists," July and Aug., 1904, Popular Science Monthly, New York City.

"Evolution Before the Origin of Species," Nov. and Dec., 1909, Popular Science Monthly, New York City.

"Meaning of Vitalism," Apr. 21, 1911, Science, New York City.

"Import of Vitalism," July 21, 1911, Science, New York City.

"Meaning of Driesch and the Meaning of Vitalism," Nov. 15, 1912. Science, New York City.

Essays in Critical Realism, 1920.

Lull, R. S., Organic Evolution, 1917, The Macmillan Co., New York City. 
MACBRIDE, E. W., Introduction to the Study of Heredity, 1924, Henry Holt \& Co., New York City.

McDougall, W., Body and Mind, 1920, The Macmillan Co., New York City.

An Outline of Psychology, 1923, Charles Scribner's Sons, New York City.

Macleod, J. J. R., Physiology and Biochemistry in Modern Medicine, 1926, C. V. Mosby Co., St. Louis, Mo.

Macleod, Jules, Quantitative Method in Biology, (University of Manchester Publication.) 1926, Longmans, Green \& Co., New York City.

McClung, C. E., "The Accessory Chromosome-Sex Determinant," Vol. 3, pp. 43-84, 1902, Biological Bulletin of the Marine Biological Laboratory, Woods Hole, Mass.

"The Unity of Life," Dec. 10, 1926, Science, New York City. "The Contribution of Biology and Its Application," March, 1927, Science, New York City.

Marshall, C. E., Microbiology, 1921, P. Blakiston's Son \& Co., Philadelphia, $\mathrm{Pa}$.

Marshall, F. H. A., Physiology of Reproduction, 1922, Longmans, Green \& Co., New York City.

Mathews, A. P., "An Important Chemical Difference Between the Eggs of the Sea Urchin and Those of the Starfish," Vol. 14, pp. 465-467, 1912, Journal of Biological Chemistry, Baltimore, Md.

MAUER, Fr., "Gewebe," in Handwörterbuch der Naturwissenschaften, 1913, Jena.

MaY, R. M., "French Institutions and Research," Jan. 21, 1927, Science, New York City.

Mayo Foundation Lectures, 1923-1924, Our Present Knowledge of Heredity, 1925, W. B. Saunders Co., Philadelphia, Pa.

Mendel, L. B., "Oxidations and Reductions in the Animal Body," (Review of the book by this title, by H. D. Dakin.) Vol. 37, p. 21, Jan. 3, 1913, Science, New York City.

"Some Tendencies in the Promotion of Chemical Research, June 10, 1927, Science, New York City.

Menge, E. J., General and Professional Biology, with Special Reference to Man. Vol. I, General Biology, Vol. II, Introductory Em- 
bryology and Comparative Anatomy, 3rd Edition, 1928, The Bruce Publishing Co., Milwaukee, Wis.

The Laws of Living Things, 1927, The Bruce Publishing Co., Milwaukee, Wis.

Merz J. T., A History of European Thought in the Nineteenth Century, 1924, University of Chicago Press, Chicago, Ill.

Metcalf, M. M., "Chromosomes in Protozoa," Paper read before the biological societies of the Pacific Coast at Berkeley, Aug. 7, 1915. "Research in Colleges and Professional Schools," April 1, 1927, Science, New York City.

Metzger, Helene, Les Concepts Scientifiques, 1927, Paris.

Meves, F., "Die Chondriosomen als Träger erblicher Anlagen," Bd. 72, pp. 816-867, 1908, Arch. f. Mikr. Anat.

MIESEs, Rassenfrage. Stammes-u. kulturgeschichtl. Untersuchung, 1919. Minot, C. S., Genetic Interpretation in the Domain of Anatomy," Vol. 4, pp. 245-263, 1904, American Journal of Anatomy, Philadelphia, Pa.

Modern Problems of Biology, 1913, P. Blakiston's Son \& Co., Philadelphia, $\mathrm{Pa}$.

Mitchelt, F. C., Logic and Law in Biology, Huxley Memorial Lecture for 1927.

Montague, W. P., Consciousness a Form of Energy, in Essays Philosophical and Psychological in Honor of Wm. James, 1908, New York City.

Morgan, C. L., Animal Behavior, 2nd Edition, 1908, London.

Instinct and Experience, 1912.

Emergent Evolution, The Gifford I.ectures delivered in the University of St. Andrews in 1922, Henry Holt \& Co., New York City. "Evolutionary Advance; Emergent and Resultant," Vol. 119, pp. 786-7, May 28, 1927. Abstract in Nature.

Morgan, C. L., AND Goodrich, E. S., "Cell Theory," in Baldrvin's Dictionary of Philosophy and Psychology, 1911, New York.

Morgan, T. H., "Half Embryos and Whole Embryos from One of the Two Blastomeres of the Frog's Egg," Bd. 10, p. 95, 1895, Anat Anz. The Development of the Frog's Egg, 1897, New York.

"Regeneration: Old and New Interpretation," pp. 185-208, 1899, 
Lectures from Biological Bulletin of the Marine Biological Laboratory, Woods Hole, Mass.

Regeneration, Vol. 7, 1901, Columbia University Biological Series, Columbia University Press, New York City.

"The Male and Female Eggs of the Phylloxerans of the Hickories." Vol. 10, pp. 201-206, 1906, Biological Bulletin of the Marine Biological Laboratory, Woods Hole, Mass.

Experimental Zoölogy, 1907, The Macmillan Co., New York City. Heredity and Sex, 1913.

Mechanism of Mendelian Heredity, 1915.

A Critique of the Theory of Evolution, 1916.

The Physical Basis of Heredity, 1919, J. B. Lippincott Co., Philadelphia, Pa.

The Theory of the Gene, 1926, Yale University Press, New Haven, Conn.

Experimental Embryology, (Full bibliography.) 1927, Columbia University Press, New York City.

"The Relation of Biology to Physics," March 4, 1927, Science, New York City.

Nachtsherm, H., "Cytologische Studien über die Geschlechtsbestimmung bei der Honigbiene (Apis mellifica L)," Bd. 11, pp. 169-241, 1913, Arch. F. Zellforsch.

Naumann, Einer C. L., Über die natürliche Nahrung der limn. Zooplanktons, 1918, University of Lund.

Die Arbeitsmethoden der regionalen Limnologie, 1921, Leipzig.

Spezielle Untersuchungen über die Ernährungs-biologie des tierischen Limnoplanktons, 1921, Leipzig. Untersuchungen über das Verteilungsproblem des limnischen Biosetons, 1921, Stockholm and Berlin.

Notizen z. Systematik d. Süsswasseralgen, 1923, Stockholm.

"Notizen z. Biologie d. Süsswasseralgen," 1924, Arch. für Botanik, Stockholm.

NeMEc, B., Das Problem der Befruchtungsvorgänge und andere zytologische Fragen, 1910, Berlin.

Noble, Edmund, Purposive Evolution; The Link Between Science and Religion, 1926, Henry Holt \& Co., New York City. 
Nordenskioeld, ERIK, Die Geschichte der Biologie, (German trans.) 1926, Jena.

Nussbaum, J., "Die Entwicklungs-mechanisch-metaplastischen Potenzen der tierischen Gewebe," Heft 17, 1912, Roux's Vorträge, Aufsätze über Entwicklungsmechanik der Organismen.

Nuttall, Geo. H. F., Blood Immunity and Blood Relationship, 1904, The Macmillan Co., New York City.

Opper, A., "Causal-morphologische Zellstudien. IV. Mitteilung: Die Explantation von Saugetiergeweben - ein der Regulation von Seiten des Organismus nicht unterworfenes Gestaltungsgeschehen," Bd. 34, pp. 132-167, 1912, Arch. f. Entw'mch.

Osborn, H. F., The Origin and Evolution of Life, 1917, Charles Scribner's Sons, New York City.

Paget, Sir Stephen, Noguchi's Researches in Infective Diseases, Nov. 21, 1913, Science, New York City.

PARKer, G. H., Biology and Social Problems, 1914, Houghton, Mifflin Co., Boston, Mass.

What Evolution Is, 1925, Harvard University Press, Cambridge, Mass.

Parker, T. J. And Hasweli, W. A., A Textbook of Zoölogy, 3rd Edition, 1921, The Macmillan Co., New York City.

Parsons, T. R., Fundamentals of Bio-Chemistry in Relation to Human Physiology, 1923, Williams \& Wilkins Co., Baltimore, Md.

Pavlov, Ivan Petrovich, The Work of the Digestive Glands, (English trans.) 1922, J. B. Lippincott Co., Philadelphia, Pa.

Conditional Reflexes; An Investigation of the Physiological Activity of the Cerebral Cortex, 1927, Oxford University Press, New York City.

Pauli, W., Physical Chemistry in the Service of Medicine, (Fischer trans.) 1906, John Wiley \& Sons, Inc., New York City.

Payne, F., "Review: Meves' The Chondriosomes as Bearers of Hereditary Qualities," Vol. 43, pages 190-192, 1909, American Naturalist, New York City.

Peabody, F. W., "The Care of the Patient," Vol. 88, p. 877, March 19, 1927, Journal of the American Medical Association, Chicago, Ill.

Perrier, J. L., The Revival of Scholastic Philosophy in the Nineteenth Century, Columbia University Press, New York City. 


\section{BIBLIOGRAPHY}

Pearl, R., Modes of Research in Genetics, 1915, The Macmillan Co., New York City.

PeARSon, KarL, The Grammar of Science, 1911.

Tables for Statisticians, 1914.

Poulton, E. B., Essays on Evolution, 1908, Oxford University Press, New York City.

PRYDE, J., Recent Advances in Biochemistry, 1926, P. Blakiston's Son \& Co., Philadelphia, Pa.

Punvetr, R. C., Mendelism, 7th Edition, 1927, The Macmillan Co., New York City.

Ramon y Cajal, (See Cajal.)

Radi, Emanuel, Geschichte der biologischen Theorien der Neuzeit, 2nd Edition, 1913, Leipzig.

Rastall, R. H., Physico-Chemical Geology, 1927, Longmans, Green \& Co., New York City.

Retzius, G., "Die Spermen des Menschen," Biologische Untersuchungen, Bd. 14, p. 205, 1909.

Reinheimer, H., "Evolution at the Crossways," p. 188, August, 1924, Review in Discovery, London, England.

REINKE, Biologische Gesetze in ihrer Besiehung zur allgemeinen Gesetslichkeit der Natur, 1921.

Reuter, E. B., "Relation of Biology to Sociology," March, 1927, American Journal of Sociology, Chicago, IIl.

Rhumbler, L., "Organe des tierischen Körpers," 1912, In Hdwb. d. Naturw.

"Correlation," 1912, In Hdwb. d. Naturce.

RIDDLE, O., "The Determination of Sex and Its Experimental Control," Vol. 15, No. 5, 1914, Bulletin of the American Academy of Medicine.

Rignano, E., "Man Not a Machine," 1926, London. Review by G. H.

Parker in Science, New York City, Sept. 2, 1927.

Ritter, WM. E., War, Science, and Civilization, 1918.

The Probable Infinity of Nature and Life, 1918, Boston.

Unity of Organism; or, The Organismal Conception of Life, 2 Vols., 1919, The Gorham Press, Boston, Mass.

Unity of the Organic Species with Special Reference to the Human Species. An Organismal Conception of Consciousness, 1919. 
Ritrer, Wm. E. ANd Bailey, E. W., The Natural History of Our Conduct, 1927, Harcourt, Brace \& Co., New York City.

Robertson, T. B., "On the Normal Rate of Growth of an Individual and Its Biochemical Significance," Bd. 25, pp. 581-614, 1908, Arch. f. Entw'mch.

Chemical Basis of Growth and Senescence, 1923, J. B. Lippincott Co., Philadelphia, Pa.

Rogers, C. G., Textbook of Comparative Physiology, 1927, McGrawHill Book Co. New York City.

Roux, W., "Über die künstliche Hervorbringung halber Embryonen durch Zerstörung einer der beiden ersten Furchungskugeln, sowie über die Nachentwicklung (Postgeneration) der fehlenden Körperhälfte," Bd. 114, pp. 113-153, 1888, Virchow's Archiv f. path. Anatomy und Physiologie.

Russell, E. S., Form and Function, 1916.

The Study of Living Things, 1924.

RuzICKA, V., "Die Frage der kernlosen Organismen und der Notwendigkeit des Kernes zum Bestehen des Zellenlebens," Bd. 28, pp. 491-505, 1907, Biol. Centralbl.

RUzzINI, Fisiogenia.

SAjous, C. E. DE M., "The Internal Secretions and Their Limitations," Vol. 20, pp. 199-210, April, 1914, American Med.

Sandon, H., The Composition and Distribution of the Protozoan Fauna of the Soil, 1927.

Schaerer, E. A., An Introduction to the Study of the Endocrine Glands and Internal Secretions, Leland Stanford Junior University Publication, University Series, Stanford University Press, Calif.

Schrader, E. G., "Zur Physiologie des Froschgehirns," Vol. 41, 1887, Arch. f. ges. Phys.

Sellards, Andrew W., "Bonds of Union Between Tropical Medicine and General Medicine," July 29, 1927, Science, New York City.

Semon, R. W., The Mneme, 1921, The Macmillan Co., New York City.

Shearcroft, W. F. F., Matter, Man and Mind, 1926, The Macmillan Co., New York City.

Shipley, Str Arthur E., Life, 1923, The Macmillan Co., New York City. 
Shull, A. F., Principles of Animal Biology, 1924, McGraw-Hill Book Co., New York City.

Skene, MacGregor, The Biology of Flowering Plants, 1924, The Macmillan Co., New York City.

Smuts, General J. C., Holism and Evolution, 1926, The Macmillan Co., New York City.

Soldas, W. J., Ancient Hunters and Their Modern Representatives, 3rd Edition, The Macmillan Co., New York City.

Spemann, Hans, "Über die Determination der ersten Organanlagen der Amphibien-Embryo," Vol. 43, pp. 448-555, 1917-1918. i-vi. Archiv für Entwicklungsmechanik.

Vol. 106, pp. i-xxii. 1925, "Hermann Brauss," Archiv für Entwicklungsmechanik.

Spemann, Hans and Falkenberg, Herman, "Über asymmetrische Entwicklung und Situs inversus viscerum bei Zwillingen und Doppelbildungen," Vol. 45, pp. 371-422, 1919. Archiv für Entwicklungsmechanik.

"Ein wissenschaftliches Bildarchiv," Vol. 47, pp. 302-305, 1920-1921. Archiv für Entwicklungsmechanik.

"Die Erzeugung tierischer Chimären durch heteroplastische embryonale Transplantation zwischen Triton cristatus und taeniatus," Vol. 48, pp. 533-570. Archiv für Entwicklungsmechanik.

Spenanan, Hans and Mangold, Hilde, "Über Induktion von Embryonanlagen durch Implantation artfremder Organisatoren," Vol. 100, pp. 599-638, 1923-1924. Archiv für Entwicklungsmechanik.

Spohn, A. ANd Rmble, O., "On the Chemical Composition of White and Yellow Egg Yolk of the Fowl and Pigeon," Vol. 41, pp. 397409, 1916, American Journal of Physiology, Baltimore, Md.

Stempeli, Walter, Zoölogie im Grundriss, 1926, Berlin, Germany.

Stiles, Walter, Photosynthesis, 1925, Longmans, Green \& Co., New York City.

Sutron, W. S., "The Chromosomes in Heredity," Vol. 4, pp. 231-248, 1903, Biological Bulletin of the Marine Biological Laboratory, Woods Hole, Mass.

Takamine, Joxichi, "The Isolation of the Active Principles of the Suprarenal Gland," Vol. 27, pp. 29-30, 1901, American Journal of Physiology, Baltimore, Md. 
Tashiro, Shrro, A Chcmical Sign of Life, 1917, Chicago.

Thomas, W. I., Source Book for Social Origins, 1909, The Gorham

Press, Boston, Mass.

Thompson, D'Arcy W., On Growth and Form, 1917, Cambridge.

Thompson, J. ARthur, The System of Animate Nature, 2 Vols., 1920,

Henry Holt \& Co., New York City.

The Control of Life, 1921, Henry Holt \& Co., New York City.

The Biology of Birds, 1923, The Macmillan Co., New York City.

Everyday Biology, 1924, Doubleday, Doran \& Co., Inc., Garden City, N. Y.

Concerning Evolution, 1925, Yale University Press, New Haven, Conn.

Article "Biology" in Encyclopedia Britannica, 13th Edition, 1926. Tillyard, R. J., The Insects of Australia and New Zealand, 1927.

Todd, Charles, "On the Recognition of the Individual by Haemolytic Methods," Vol. 3, No. 2, pp. 123-130, 1913, Genetics, Brooklyn, N. Y.

Torrey, Harry Beal, "Modern Scientific Thought and Its Influence on Philosophy," January, 1913, Popular Science Monthly, New York City.

Tutron, A. E. H., The Natural History of Ice and Snow, 1927.

Uexkuell, Baron J. Von, Theoretische Biologie, 1920, Berlin.

Van Klooster, H. S., "Nobel Prizes, Peace and Progress of Science," p. 259, Sept. 18, 1925, Science, New York City.

Vialleton, L., Membres et Ccintures des Vertébrés Tétrapodes. Critique Morphologique du Transformisme, 1924, Paris.

Waller, H. E., "The Clinical Importance of Considering the Correlation of the Internal Secretions," Vol. 20, pp. 27i-284, April, 1914, American Medicine, New York City.

Walter, H. E., Genetics, 1922, The Macmillan Co., New York City. Wasmann, E., Instinct and Intelligence in the Animal Kingdom, 2nd Edition, 1903, St. Louis, Mo.

IVeismann, A., The Germ-Plasm; A Theory of Heredity, (Translated by W. N. Parker and Harriet Rönnfeldt.) 1912, London.

Wells, W. R., The Biological Foundation of Belief, 1921, Boston.

Wendr, G. L., "Identity of Atomic Weight Among Different Elements," Vol. 47, p. 442, 1918, Science, New York City. 
Wheeler, W. M., "A Contribution to Insect Embryology," Vol. 8, pp. 1-160, 1893, Journal of Morphology and Physiology, Philadelphia, $\mathrm{Pa}$.

Ants; Their Structure, Development and Behavior, Columbia University Biological Series, Vol. 9, 1910, Columbia University Press, New York City.

Social Life Among the Insects, 1923, Harcourt, Brace \& Co., New York City.

Emergent Evolution, 1927.

Whitehead, A. N., Science and the Modern World, 1925, The Macmillan Co., New York City.

Whitman, C. O., "The Seat of Formative and Regenerative Energy," Vol. 2, pp. 27-49, 1888, Journal of Morphology and Physiology, Philadelphia, $\mathrm{Pa}$.

"The Inadequacy of the Cell Theory," pp. 105-124, 1893, Biological Bulletin of the Marine Biological Laboratory, Woods Hole, Mass. "Animal Behavior," pp. 285-338, 1898, Biological Bulletin of the Marine Biological Laboratory, Woods Hole, Mass.

Whitney, W. R., "The Stimulation of Research in Pure Science Which Has Resulted from the Needs of Engineers and of Industry," March 25, 1927, Science, New York City.

Wuliams, H. S., Geological Biology, 1895, New York City.

Wilson, E. B., "Amphioxus, and the Mosaic Theory of Development," Vol. 8, pp. 579-638, 1893, Journal of Morphology and Physiology, Philadelphia, $\mathrm{Pa}$.

"The Mosaic Theory of Development," pp. 1-14, 1893, Biological Bulletin of the Marine Biological Laboratory, Woods Hole, Mass. The Cell in Development and Inheritance, Vol. 4, 1900, Columbia University Biological Series, Columbia University Press, New York City.

"Mendel's Principles of Heredity and the Maturation of the Germ Cells," Vol. 16, pp. 991-993, 1902, Science, New York City.

"The Sex Chromosomes," Bd. 77, pp. 249-271, 1911, Archiv für mikr. Anat.

"Heredity and Microscopical Research," Vol. 37, pp. 814-826, 1913, Science, New York City. 
"The Bearing of Cytological Research on Heredity," Vol. 88, pp. 333-352, 1914, Proc. R. Soc. London.

The Cell in Development and Heredity, 3rd Edition, 1925, The Macmillan Co., New York City.

Wrlson, Edwiv Brdwell, "What Is Statistics?," June 17, 1927, Science, New York City.

Windle, Str Bertram, The Church and Science, 1917, B. Herder Book Co., St. Louis, Mo.

Facts and Theories; Being a Consideration of Some Biological Conceptions of Today, 1917, B. Herder Book Co., St. Louis, Mo.

Science and Morals and Other Essays, 1919, P. J. Kenedy \& Sons, New York City.

Wissler, Clark, Man and Culture, 1923, T. Y. Crowell Co., New York City.

WoodrufF, L. L., "History of Biology," March, 1921, Scientific Monthly, New York City.

Foundations of Biology, 3rd Edition, 1927, The Macmillan Co., New York City.

Woolard, H. H., Recent Advances in Anatomy, 1927.

Yerkes, Robert M., Almost Human, 1925, Century Co., New York City.

The Mind of a Gorilla, (Genetic Psychology Monograph.) Vol. 2, Nos. 1 and 2, 1926-1927, Clark University Press, Worcester, Mass. Yerkes, Robert M. ANd Learned, W. B., Chimpanzee Intelligence and Its Vocal Expressions, 1925, Williams \& Wilkins Co., Baltimore, Md.

\section{BOOKS, REPORTS, AND ARTICLES NOT MENTIONED UNDER AUTHORS}

The American Year Book. Annually 1909 to 1919 inclusive, and 1925. "The Association of German Scientific Men and Physicians," Science, October 1, 1926. Under Science News.

Berichte über die wissenschaftliche Biologie. Rona and Spiro, Berlin. Annual.

"British Association for the Advancement of Science," Report of the Ninety-second Meeting, 1924. 
"British Association for the Advancement of Science," Science, August 27, 1926, under Science News.

France, Raoul H., Der Begründer der Lebenslehre. Festschrift zu s. 50 Geburtstag. A series of original articles by his former students and coworkers, 1924. Stuttgart.

"The French Association for the Advancement of Science," Science, August 13, 1926, under Science News.

"Medical Report of the Hamilton Rice Seventh Expedition to the Amazon, in Conjunction with the Department of Tropical Medicine of Harvard University, 1924-1925." Contributions from the Harvard Institute for Tropical Biology and Medicine, No. IV.

"Neue Studien über die Reifung der Geschlechtszellen," by A. and

K. E. Schreiner, Arch. de Biologie, Vol. XX and XXI, Liege, 1905 and 1906; Anatom. Anseiger, Bd. XXIX, Jena, 1906; and Mathematisk-Naturwidenskabslige Klasse. Kristiania, 1907.

Nova Guinea. Résultats de l'expéd. Scientif. Néerland. à la Nouv. Guinee. 1917.

Recent Developments in the Social Sciences. Lippincott's Sociological Series, 1927.

Revista Chilena de Historia Naturas. Santiago de Chile.

"Tropical Agriculture," Science, September 10, 1926, under Science News.

Williams and Wilkins' Physiological Reviews.

\section{INDICES}

Index Biologorum. List of investigators, laboratories and periodicals. Berlin.

Biological Abstracts. A comprehensive Abstracting and Indexing Journal of the World's Literature in Theoretical and Applied Biology, exclusive of Clinical Medicine. Published under the Auspices of the Union of American Biological Societies. Philadelphia.

Tabulae Biologicae. 5 Vols., 1925. Berlin. This is really an encyclopedia of formulae in the varicus laboratory sciences and indispensible for all research workers. 



\section{INDEX}

\section{Subjects}

Acquired characteristics, 51, 111

Agriculture, 38

Albuminoid substances, 114

Algeria, 26

America, Central, 103

American College of Surgeons, 1

Americas, The, 92

Ancestors, primitive, 53

Amino acids in metabolism, 106

Anaphylaxis, 111

Andrase, 84

Anglo-Saxon vs. Gallic genius, $57,64,71$

Animal psychology, 111

Antirabies sera, 102

Apathy, 14

Asia, 121

Australia, 26, 122

Austria, 16, 30, 104

Axial gradient theory, 72,79

Bacteriophage, 42, 110

Balkan, Peninsula, xi

Belgium, 105

Biochemistry, 39

Biological, abstracts, 21, 94; medicine, 117; statistics, 107; success, 14; theories, 109; workers, 92

Biology, importance of, 43 ; social, 107

Boer War, 41
Brazilians, 101, 120

Breeding better plants and animals, 49

British Isles, 105

Brno, University of, 108

Bubonic plague, 122

Buenos Aires, 101

Butantan, 99

California Institute of Technology, 94

Canada, 24, 25, 92, 111

Cancer, 45, 115

Capillaries, work on, 119

Catalysis, 113

Categories, biological, 35

Cave man, 53

Cell, cleavage, 109; doctrine, 22; structure, 106; study, object of, 11 ; theory, 73

Central Europe, 24

Chcetopterus, 73

Chagas disease, 100

Chemical integration, 40; physical explanations, 34

Chemistry, 108, 110, 113, 116, 119

Chile, 103; University of, 103

China, xi, 27

Chlorophyll, 113

Chromosomes, 35, 36; conjugation and reduction of, 117 
Clinica, La, xi

Color, theory of, 113

Comparative anatomy, 109

Concepcion, University of, 103

Conditional reflex, 117

Congo, The, 26

Conjugation and reduction of chromosomes, 117

Constantin, 26

Cordoba, 102; University of, vii, 1, 98

Costa Rica, 103

Criminality, 45

Criticism a generation behind publication, 57

Crop increase, 49

Cross section of biological thought, 48

Cruz, Oswaldo Instituto, 99

Cuba, 103

Cytochrome, 40, 107

Cytology, 36; mechanics of, 109

Cytomorphosis, 22

Cytoplasm, 106, 115

Czechoslovakia, 108

Darwinism, 53

Death, development of, 22

Denmark, 119

Development, mechanism of, 115

Digestive glands, 117

Diphtheria, 41, 115

Disease, 45

Dog experiment with parotid gland, 10

Downfall of prehistoric American civilization, 7

Dysentery bacillus, 122
Eel, 38

Egypt, xi

Electrocardiograph, 114

Electromotive chemistry, 113

Embryology, 115; experimental, 32

Emergent evolution, 53, 72, 87, 106, 111

Empire Marketing Board, 105

Entomology, 25, 46, 116

Environment, 45, 46; vs. heredity, 45,52

Epidemics and war, 6

Europe, 104

Evolution, 65, 116; emergent, 72, $87,106,111$; mechanistic, 53 ; mental factors in, 107 ; organic, 51; purposive, 96

Explanations and interpretations, 48

Eye development, 115

Facts and findings, 20

Fads and fancies, 44

Fermentation, 113

Fifth Estate, 16

Finland, 119

Fisheries, 50, 118; research, 25

Fluorine, 110

Food, deficiency, 13; excess, 13

France, 109

French scientists, 26

Friendship, scholarship of, 65

Fruit fly, birthday of, 35

Gallic vs. Anglo-Saxon genius, $57,64,71$

Genes, 35, 36

Genetics, 27, 45, 115; applied, 49 
Geographical aspects of biology, 24,26

Germany, 16, 24, 30, 111

Gland grafting, 117

Glutathione, 107

Great Britain, 26

Guinea, 26

Gynase, 84

Hæmatozoöns, 111

Heart-action currents, 114

Herd instincts, 107, 112

Heredity, 13, 46; vs. environment, 45,52

Heterogenesis and evolution, 116

Historian vs. philosopher, 2

Holland, 30, 111, 114

Honesty of scientific men, 55

Hormone, deficiency, 13; excess, 13

Human biology, 50

Immigration affected by biology, 45

Immortality, 22

Immunity, 114, 116

Impetus of experimentation, 44

India, 121

Indo-China, 26

Infantile paralysis, 122

Infection, 13

Insect control, 49

Instincts of the herd, 107, 112

Institute of Physicochemical Biology, 110

Instituto Oswaldo Cruz, 99

Insulin, 42

Insurance investigation of shortening of life, 12
Ionization hypothesis, 119

Italy, 114

Japan, 26, 122

Labor vs. intelligence, 15

La Clinica, xi

Latin America, 7, 97

Life, notion of, 22 ; nature of, 45

Limiting science, 70

Malaria, 40, 101, 107, 111, 115

Manias, biological, 24

Mar Chiquita, 102

Marquis wheat, 25

Materialism, 112

Mechanism, 64; vs. vitalism, 62,66

Mechanistic evolution, 53; explanation, 44

Medicine, 49, 107, 113, 117

Mendel's hypothesis, 31

Mental factors in evolution, 107

Metabolic gradient, 72 ; theory of sex, 72, 82, 112

Metabolism, amino acids in, 39, 106

Metamorphosis of Amphibia, 115

Mexico, 104, 111

Microstomum, 81

Minerva's list of universities, $\mathrm{xi}$

Modern problems of biology, 22

Molecular structures, 114

Morocco, 26

Mosaic theory of development, 73

Motive vs. obligation, 64

Mutation theory, 30, 114; origin of, 111

National Research Council, 94

Negative side of biology, 51 
Nervous system, 115; of plants, 121

New Zealand, 122

Nobel Institute, 118

Norway, 24, 117

Nova Guinea, 114

Nucleic acid, derivatives of, 114

Object of science, 3

Obligation vs. motive, 64

Ocean depths, 118

Order of importance, 54

Organic syntheses, 110

Organisationcentrum theory, 72 , 77

Organismal theory, 72

Organism, unity of, 74

Origin of species, 111

Otago, University of, 122

Outstanding biological workers, 92

Oxalines, 113

Parasitology, 49

Parthenogenesis, artificial, 37, 110

Philippines, xi

Philosophical progress, 54

Philosopher vs. historian, 2

Philosophy, 46; and modern scientific thought, 59

Photographer vs. scientist, 4

Photosynthesis, artificial, 40, 107

Physical apathy, 14; trauma, 13

Physics, 34, 116

Physiology, 52

Plankton, 39, 106, 117

Plant control, 49

Plasmogeny, 72, 85

Poison, 13
Poland, 116

Portuguese, 120

Pragmatism, 60

Prague, University of, 108

Preventive medicine, 40

Pribilof Islands, 26

Primitive ancestors, 53

Probity, intellectual, 55

Progress, philosophical, 54; scientific, 16

Prophylaxis, 113

Protoplasm, 45, 108

Protozoan reproduction, 115

Provocative theories, 72

Pseudoresearch, 18

Psychic, apathy, 14; trauma, 14

Psychology, animal, 111; comparative, 38

Psychological reactions of biologists, 23

Purposive evolution, 96

Quarterly Review of Biology, xi

Questions asked of world's biologists, viii

Racial psychology, 57

Radioactivity, 108

Reduction of chromosomes, 117

Reifung der Geschlechtszellen, 117

Revolutions, 28

Rockefeller Institute, 101, 119

Rosario, 102

Roux's experiment, 32

Rubber, chemistry of, 119

Russia, 16, 17, 26, 116

Salt deposits, 114

Sao Paulo, 99 
Scandinavia, 24, 117

Science, definition of, 3 ; influence of on philosophy, 59; in our day but not of it, 55 ; limitation of, 70; object of, 3

Scientific laws always negative, 58 ; progress, 16

Seals, 26

Selective elimination, 90

Senegal-Niger, 26

Serotherapy, 111, 113

Sex, determination of, 22 ; metabolic theory of, 72, 82, 112

Siboga Expedition, 114

Slavery, 29

Snake farm, 99

Social biology, 107

Social Psychology, Journal of, xi South Africa, xi

Spain, 27, 120

Spectrotherapy, 108

Splenomegaly, 101

Statistics, biological, 107

Statocysts, 109

Success to a biologist, 14

Surgeons, American College of, 1 Sweden, 118

Switzerland, 121

Sydney, University of, 122

Syphilis, 122

Symbiosis, 109

Synthesis of ammonia, 113; of indigo, 113; of sugars and proteins, 113 ; organic, 110
Technique, scientific, 110

Terpenes, 113

Theories, axial gradient, 72, 79; biological, 109; color, 113; emergent evolution, 72, 87; metabolic gradient, 72 ; metabolic, of sex, 72, 112; mosaic, of development, 73 ; mutation, 114 ; organismal, 72 ; organisationcentrum, 72, 77; plasmogeny, 72

Thermodynamics, 113

Thyroid gland reaction, 115, 121

Tissue culture, 115

Transformation of energy, 114

Treponema pallidum, 122

Tropisms, 37

Tuberculosis, 113

Tunis, 26

Typhoid fever, 7, 41; injections, 100

United States, 26, 27, 62, 93

Variations and modifications, 51

Violet rays, 119

Vitalism vs. mechanism, 62,66 , 112

Vitamins, 39, 50

Viruses, filterable, 45

Votes and science, 62

War, biology of, 64

Western Front, 41

Whistle experiment on dog, 10

Wrong use of science, 17

Yellow fever, 6, 41 
Proper NAMES

Agar, W. E., 123

Aldrich, J. M., 57, 71

Alexander the Great, 56

Allen, Dr., 39, 106

Alverdes, F., 112

Aristotle, 74

Arrhenius, S. A., 119

Artrom, Dr., 115

Aschan, O., 119

Aston, Francis Wm., 108

Babak, Ed., 109

Bagehot, Walter, 15

Baltzer, Dr., 37, 110

Baly, Edward C. C., 40, 107

Balzac, 63

Banting, Frederick G., 42, 93

Barany, R., 105

Barker, Lewellys, 18

Bateson, Wm., 107

Bäyer, Adolph von, 113

Beach, Frederick E., 58, 71

Behring, E. A. von, 113

Beneden, E. van, 108

Benham, Prof., 123

Bensley, B. A., 51

Berlese, Dr., 116

Bern, Dr., 112

Bernard, Noel, 110

Besredka, Dr., 8, 117

Bichat, Marie François X, 72

Bordet, Jules, 105

Bose, Sir Jagadis Chunder, 121

Boveri, Theodore, 36, 108
Brazil, Vital, 99, 100

Brieger, Prof., 8

Broch, Hjalmar, 24

Bruschettini, Prof., 8, 115

Buchanan, J. William, 86, 91

Buchner, Eduard, 113

Cæsar, 56

Cajal, S. Ramon y, 28, 120

Carrel, Alexis, 37, 94

Celli, Dr., 115

Chagas, Carlos, 99, 100

Chambers, Robert, 38, 95

Chantemesse, Prof., 8

Chasles, M. Michel, 56

Child, C. M., 76, 94

Chilton, Prof., 123

Cid, The, 56

Cleopatra, 56

Cleveland, L. R., 95, 110

Cockayne, Leonard, 123

Cockrell, T. D. A., 17, 19, 63, 71

Columbus, Christopher, 62

Conklin, E. G., 51, 95, 97

Coolidge, President, 16

Cooper, Duff, 71

Correns, Carl, 30, 113

Cortonei, Dr., 115

Cromwell, 27

Cruz, Oswaldo, 41

Curie, Marie, 116

d'Herrelle, F., 42, 110

Darbishire, A. D., 9, 19 
De Vries, Hugo, 30, 104, 113, 114

Delage, Yves, 37, 110

Dewey, John, 60, 61

Dontchef-Dezeuse, M., 117

Driesch, Hans, 32, 33, 112

Eberth, Carl Joseph, 8

Ehrlich, Paul, 113

Einthoven, Willem, 114

Enrigues, Dr., 115

Fichera, Dr., 115

Finlay, Carlos, 41, 103

Finsen, N. R., 119

Fischer, E., 106, 113

Fisk, Eugene Lyman, 19

Fric, A., 109

Frisch, F. von, 112

Gaffky, George, 8

Galileo, 56

Galton, Sir Francis, 107

Gamble, F. W., 79

Gardiner, G. Stanley, 2i, 50

Gates, R. Ruggles, 93

Gerhard, Wm., 7

Ghigi, Dr., 115

Giacomini, Dr., 115

Giardina, Dr., 115

Goethe, 52

Goldschmidt, R., 82, 112

Golgi, C., 115

Gran, H. H., 117

Grassi, Dr., 115

Grignard, Vikto, 110

Gullstrand, Alvar, 119

Gunnerus, Johan Ernst, 25, 118
Haber, F., 113

Haffkine, Dr., 9

Handlirsch, Anton, 105

Hardy, Dr., 106

Harrison, Ross G., 37, 94

Haswell, William A., 22

Herbst, Curt, 113

Hertwig, R., 83

Herrera, A. L., 85, 104

Hill, A. V., 107

Hjort, Johan, 118

Hoff, L. H. van't, 114

Hopkins, Sir F. Gowland, 29, 106, 107

Houssay, Bernardo, 102

Howard, L. O., 39, 95

Huxham, Dr., 7

Jakob, C., 102

James, Wm., 60

Janda, V., 109

Jennings, H. S., 37, 52, 88, 91, 95

Joseph of Egypt, 15

Keilin, D., 40, 107, 112

Kellogg, Vernon L., 26, 47, 63, 71

King, Helen, 83

Kitasato, Shifasabur, 8, 122

Koch, Robert, 113

Kocher, Theodore, 121

Koford, C. A., 95, 112

Kohler, Prof., 96

Kolle, Dr., 8

Korschminsky, S., 116

Kossel, Albrecht, 114

Krause, W., 120

Krogh, A., 119 
Lacroix, Alfred, 26

Lamartine, 2

Langley, Prof., 16

Laveran, C. L. A., 111

Lavoisier, 16

Lazarus, 56

Le Blanc, Dr., 16

Learned, Mrs., 96

Levi, Dr., 115

Lewes, G. H., 75

Li Hung Chang, 14

Lillie, F. R., 73

Lipschutz, A., 103

Little, Arthur D., Dr., 15, 19

Locy, Wm. A., vii

Loeb, Jagues, 37, 73, 94

Lotsy, Prof., 123

Louis XIV, 56

Lovejoy, Arthur, 53, 96

Luke, Saint, 56

Lutz, Adolph, 100

Mac Leod, John J. R., 93

McClung, C. E., 19, 55, 71

Manson, Sir Patrick, 103

Marchiafava, Prof., 115

Martin, Franklin H., 1

Mary Magdalen, 56

Mendel, Johan Gregor, 27, 31, 104

Metcalf, Prof., 57

Metchnikoff, Prof., 8, 116

Meyerhoff, O., 114

Minot, C. S., 22, 47

Moissan, Henri, 110

Morgan, C. Lloyd, 53, 75, 87, 106
Morgan, Thos. Hunt, 27, 36, 47, $52,82,95,96$

Mrazek, A., 109

Mueller, Johannes, 21

Murray, Sir John, 118

Napoleon, 27

Naumann, Einer, 119

Nelson, Prof., 123

Nemec, Prof., 109

Nernst, Walther, 113

Newton, 56

Nikolai, Prof., 64

Noble, Edmund, 53, 96

Noe, Juan, 103

Noguchi, Hideyo, 122

Osborn, Henry Fairfield, 53

Ostwald, Wilhelm, 113

Paget, S., 122

Parker, G. H., 38, 50, 82, 95

Parker, T. Jeffery, 122

Pascal, 56

Pasteur, Louis, 9, 110

Pavlov, Ivan Petrovich, 117

Peabody, F. W., 56, 71

Pearson, E. L., 71

Pearson, Karl, 107

Pentimalli, Dr., 115

Peter, Saint, 56

Pfeiffer, Dr., 8

Philpot, Prof., 123

Pierantoni, Dr., 109

Plato, 56

Pliny, 56 
Plotinkow, Prof., 17, 117

Poincairé, Prof., 57, 64

Pompey, 56

Porter, Carlos E., 103

Pregl, Friederich, 38, 105

Priestley, 16

Pritchett, Dr., 18

Purkinje, J. E., 108

Purkyne, J. E., 108

Rabelais, 56

Radl, Prof., 109

Raffaele, Dr., 115

Ramon y Cajal, (See Cajal)

Ramsay, Sir William, 108

Rangold, Dr., 113

Reed, Major Walter, 41, 96, 103

Richards, William, 96

Richet, Charles, 111

Riddle, Dr., 82, 83

Ritter, William E., 47, 52, 53, $63,71,73,74,95,96$

Ross, Sir Ronald, 103, 107

Roux, William, 27, 32, 112

Ruddenbrock, Prof., von, 113

Russell, E. S., 107

Rutherford, Sir Ernest, 108

Ruzzini, Dr., 115

Sabatier, Paul, 110

Sars, Georg Ossian, 25, 118

Sars, Michael, 25, 118

Sappho, 56

Saunders, Charles Edward, 25, 93

Schleiden, Matthias Jakob, 72

Schreiner, K. E., 117

Schreiner, Mrs., A., 117
Schwann, Theodore, 72

Schwegler, Prof., 64

Scripps, E. W., 29

Shakespeare, 56

Silvestie, Dr., 116

Sklodowska, Marie Curie, 116

Slye, Maud, 42

Smith, Elliott, 107

Smith, Stephen, 11, 19

Soddy, Frederick, 108

Spemann, Hans, 77, 78, 113

Spencer, Herfut, 59

Steinach, Eugen, 105, 117

Studnicka, E., 109

Sulc, K., 109

Svedberg, Theodore, 119

Thienemann, Prof., 112

Thomson, J. Arthur, 34, 39, 47

Tillyard, Prof., 123

Torrey, H. B., 58, 71

Tracy, H. C., 96

Trotter, W., 107

Tschermak, Erich, 30, 104, 105,

113

Uexkull, Jacob von, 113

Vejdovsky, F., 109

Virgil, 56

Voronoff, Serge, 26, 117

Wallach, Otto, 113

Wassermann, Prof., 8

Weber, Prof., 114

Weismann, Prof., 27 
Wenig, Prof., 109

Werner, Alfred, 121

Wernicki, Paul, 102

Wheeler, W. M., 52, 53

Whitehead, A. N., 75

Whitman, C. O., 73

Whitney, Dr., 83

Widal, Prof., 8

Willcock, Dr., 39, 106

William II, 7
Willstätter, Richard, 113

Wilson, Edmund B., 27, 73, 76, 96

Wright, Sir Almroth, 8

Wundt, Wm., 10

Yerkes, Robert, 96

Zsigmondy, Richard, 105 




\section{To Those Interested in \\ The Progress of Biology \\ Investigatory and Didactic}

We submit the following Record for the 1928 period:

The Achievement

The beginning of this school year (the fifth after publication) was marked by an increase of more than $331 / 3$ per cent new adoptions of Menge's GENERAL AND PROFESSIONAL BIOLOGY, bringing this standard text for colleges and universities into its third edition and its fourth printing.

More than 100 colleges and universities, located in 34 different states, have now adopted this text for classroom use, ranging from Johns Hopkins University in the East to North Pacific College in the West.

The Committee of Biologists appointed by a foreign nation to make a study of the world's biology texts for secondary schools, has just chosen Menge's THE LAWS OF LIVING THINGS as the most perfect example of what a high-school textbook on that subject should be. The book is now being translated into Spanish by order of the Minister of Public Instruction. it will be printed officially by the Government and immediately becomes the National textbook on biology for secondary schools of that nation.

The author's SURVEY OF NATIONAL TRENDS IN BIOLOGY has just been completed and is ready for publication. In this survey Dr. Menge was assisted by many of the bestknown biologists of seventeen foreign lands. 
The three fundamental, as well as original, works here mentioned brought the author the appointment to the first International GuestLectureship ever extended by the National Universities and the Learned Societies of the great nations of South America, to a North American biologist. The same works also brought him membership in various distinguished foreign scientific societies.

\section{The Report of Eminent Men on the Above Work}

The foremost leaders in seven fields of science -Biology, Embryology, Comparative Anatomy, Neurology, Medicine, and even Etymology have written personal letters to the author or publishers, or have written long and glowing commendations in the leading scientific journals of four continents, regarding the originality, worth, comprehensiveness, and clarity of the books mentioned above. Among such men we find the world's greatest biologist, Hugo De Vries; the world's greatest histologist and neurologist, Ramon y Cajal ; our own beloved William A. Locy, and a host of others.

Immediately after its publication, the Official Organ of the Surgeon General of the United States, devoted more than four full pages to commending Dr. Menge's work, classifying his GENERAL AND PROFESSIONAL BIOLOGY as a pioneer work in "that it marked a new departure in the teaching of biology" and recommending it "for wide acceptance as a textbook in high schools, colleges, and pre-medical schools."

The Suggested Explanation

The author, Edward J. Menge, Ph.D., Sc.D., Director of the Department of Animal Biology in Marquette University, had, before beginning 
his work as a writer of successful textbooks, made a first-hand investigation of biological work and teaching in the leading universities of the United States and thirteen foreign lands, thus gaining an educational and cultural background that few American scientists possess.

$\mathrm{He}$ is both a trained biologist and a trained psychologist, thus understanding not only the problems to be presented but the presentation as well.

He has taken all laboratory courses offered in the regular medical course of American schools of medicine, thus understanding, particularly, the needs and problems of the medical and dental student.

He has worked out a consistent terminology in General Biology and Physiology not only in the High-School Course, but in General Biology, Embryology, and Comparative Anatomy for the College Course as well. An example of the comprehensiveness of the text can be suggested by noting that although medical writers use some ten different names for the "chondriosome," alone, for instance, the student need but to refer to the index under any one of these to learn immediately that all pertain to the selfsame factor.

$\mathrm{He}$ is the only American biologist who has written three accepted texts (though bound in two volumes) in three sciences-General Biology, Embryology, and Comparative Anatomy.

\section{The Standard of Comparison}

If the VALUE of a college textbook is determined by those most capable of passing judgment thereon-the heads of departments in charge of the particular subject-in our colleges and universities :

If the JUDGMENT of such men is expressed 
only after careful study and comparison with other books in the same field, as to content, completeness, originality, clarity, and "teachability":

If the DECISION reached from such study and comparison is shown by the number of adoptions for class use which follow:

And ....

If the CORRECTNESS of that decision is demonstrated by the continued use and a yearly increase in new adoptions:

Then, from the Record just given, the conclusion follows that

\section{Menge's \\ GENERAL AND PROFESSIONAL BIOLOGY}

is at this moment, the most OUTSTANDING College Textbook in the English Language;

And if a textbook for Secondary Schools is chosen through Competitive Selection by a Committee of distinguished foreign scholars and educators as being best for the purpose for which it was written, then the conclusion follows that Menge's

THE LAWS OF LIVING THINGS

is, at this moment, the OUTSTANDING HighSchool textbook on Biology in any language.

GENERAL AND PROFESSIONAL BIOLOGY

Volume I, (General Biology) Atho-leather, 484 pages, $61 / 4$ by $91 / 4 \ldots \ldots \ldots \ldots . . .$. . Frice $\$ 3.50$

Volume II, (Introductory Embryology and Comparative Anatomy) Atho-leather, 498 pages, $61 / 4$ by $91 / 4 \ldots \ldots \ldots \ldots \ldots$. Price $\$ 4.00$

THE LAWS OF LIVING THINGS

Cloth, 530 pages, $51 / 2$ by $8 \ldots \ldots \ldots \ldots$. Price $\$ 1.72$ 

